\title{
Synthesis gas solubility in Fischer-Tropsch slurry: Final report
}

Chao, K. C, I, L, H.M.

Purdue Univ. Larayette, IN (USA). School of Chemical Engineering

Reprodiced and Distributed by:

U.S. DEPARTMENT OF ENERGY

Office of Scientific and Technical Infer mation P. .. Box 62

Oak Rióge, 1 N 37831 


\section{DISCLAIMER}

This report was prepared as an account of work sponsored by an agency of the United States Government. Neither the United States Government nor any agency Thereof, nor any of their employees, makes any warranty, express or implied, or assumes any legal liability or responsibility for the accuracy, completeness, or usefulness of any information, apparatus, product, or process disclosed, or represents that its use would not infringe privately owned rights. Reference herein to any specific commercial product, process, or service by trade name, trademark, manufacturer, or otherwise does not necessarily constitute or imply its endorsement, recommendation, or favoring by the United States Government or any agency thereof. The views and opinions of authors expressed herein do not necessarily state or reflect those of the United States Government or any agency thereof. 


\section{DISCLAIMER}

Portions of this document may be illegible in electronic image products. Images are produced from the best available original document. 
DOE/PC/70024-T9

(DE88006851)

Distribution Category UC-108

\section{Final Report}

to

Department of Energy

Pittsburgh Energy Technology Center

Contract No. DE-AC22-84PC70024

on

Synthesis Gas Solubility in

Fischer-Tropsch Slurry

Principal Investigators

K.C. Chao and H.M. Lin

School of Chemical Engineering

Purdue University

West Lafayette, IN 47907

for

Contract Period: 9/10/84 - 7/20/87 
LIST OF TABLES............................................ i-iii

LIST OF FIGURES......................................... iv-vij.

SUMMARY ....................................................

Chapter 1. INTRODUCTION.................................. 4

Chapter 2. EXPERIMENTAL APPARATUS AND

PROCEDURE ...................................... 6

Chapter 3. EXPERIMENTAL RESULTS...................... 10

Chapter 4. CORRELATION WITH KRICHEVSKYKASARNOVSKY EQUATION...................... 15

Chapter 5. CORRELATION WITH EQUATION OF STATE ....................................... 17

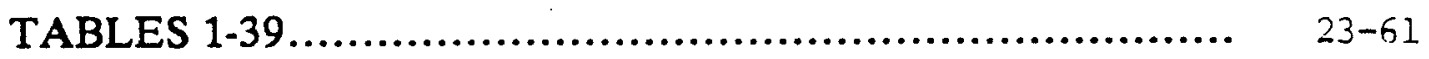

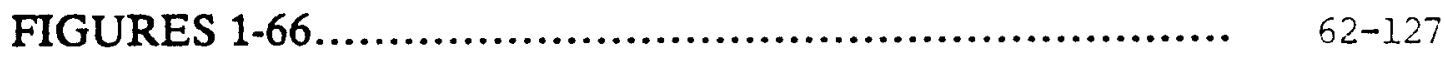

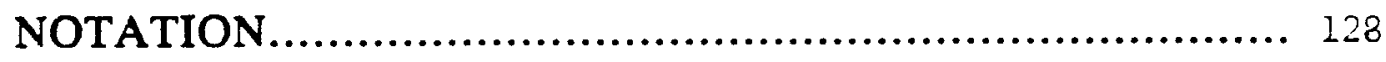

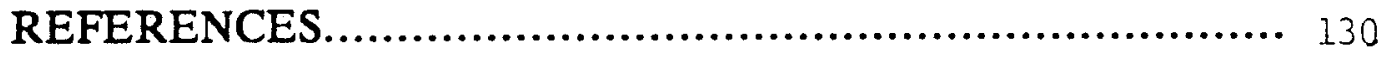

APPENDIX A Computer Program for the Calculation of Gas Solubility......................... $\quad 132$ 


\section{LIST OF TABLES}

Table

Page

1. Hydrogen + n-Eicosane VLE Data.............................. 23

2. Hydrogen + n-Octacosane VLE Data............................ 24

3. Hydrogen + n-Hexatriacontane VLE Data........................ 25

4. Carbon Monoxide + n-Eicosane VLE Data....................... 26

5. Carbon Monoxide + n-Octacosane VLE Data...................... 27

6. Carbon Monoxide + n-Hexatriacontane VLE Data................... 28

7. Methane + n-Eicosane VLE Data................................ 29

8. Methane + n-Octacosane VLE Data.............................. 30

9. Methane + n-Hexatriacontane VLE Data............................. 31

10. Ethane + n-Eicosane VLE Data................................. 32

11. Ethane + n-Octacosane VLE Data................................ 33

12. Ethane + n-Hexatriacontane VLE Data.............................34

13. Ethylene + n-Eicosane VLE Data.................................35

14. Ethylene + D-Octacosane VLE Data...............................36

15. Ethylene + n-Hexatriacontane VLE Data........................... 37

16. Carbon Dioxide + n-Eicosane VLE Data............................38

17. Carbon Dioxide + n-Octacosane VLE Data.............................39

18. Carbon Dioxide + n-Hexatriacontane VLE Data.....................40

19. Solubility Data of Synthesis Gas in n-Octacosane.......................41

20. Hydrogen Solubility in Mobil Wax...............................4 42 
Table

21. Carbon Monoxide Solubility in Mobil Wax.......................... 43

22. Methane Solubility in Mobil Wax................................. 44

23. Ethane Solubility in Mobil Wax.................................... 45

24. Carbon Dioxide Solubility in Mobil Wax........................... 46

25. Hydrogen Solubility in SASOL Wax.............................. 47

26. Carbon Monoxide Solubility in SASOL Wax...................... 48

27. Methane Solubility in SASOL Wax................................ 49

28. Ethane Solubility in SASOL Wax................................ 50

29. Ethylene Solubility in SASOL Wax.............................. 51

30. Carbon Dioxide Solubility in SASOL Wax......................... 52

31. Henry's Constants $(\mathrm{H})$ and Partial Molar Volumes at Infinite Dilution $\left(\overline{\mathrm{v}}^{-x}\right)$ of Gases in $\mathrm{n}-\mathrm{C}_{20}, \mathrm{n}-\mathrm{C}_{28}$,

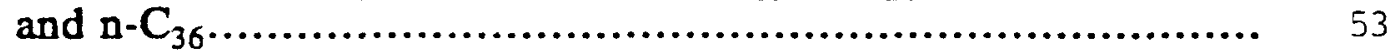

32. Physical Properties and van der Waals' Volumes of Substances....................................................... 54

33. Comparison of the Modified Soave Equation Calculated Gas Solubilities in n-Eicosane with Experimental Data................... 55

34. Comparison of the Modified Soave Equation Calculated Gas Solubilities in n-Octacosane with Experimental Data................. 56

35. Comparison of the Modified Soave Equation Calculated Gas Solubilities in n-Hexatriacontane with Experimental Data............ 57

36. Correlation of $\mathbf{A}_{\mathrm{ij}}$ by Molecular Weight of n-Paraffins.............. 58 
Table

37. Comparison of Calculated Gas Solubilities of Synthesis Gas Mixtures in n-Octacosane with Experimental Data.................... 59

38. Comparison of Calculated Gas Solubilities in Mobil Wax with Experimental Data............................................... 60

39. Comparison of Calculated Gas Solubilities in SASOL Wax with Experimental Data.................................................. 


\section{LIST OF FIGURES}

Figure

1. Vapor-Liquid Equilibrium Apparatus.............................. 62

2. Mole Fraction of $\mathrm{CO}_{2}$ in Saturated Vapor in $\mathrm{CO}_{2}+$ Toluene

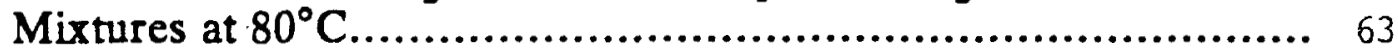

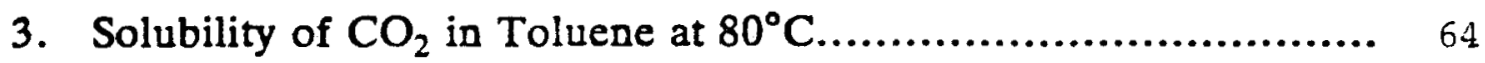

4. Solubility of Hydrogen in n-Eicosane............................... 65

5. Solubility of Hydrogen in n-Octacosane............................. 66

6. Solubility of Hydrogen in n-Hexatriacontane........................ 67

7. Solubility of Carbon Monoxide in n-Eicosane........................ 68

8. Solubility of Carbon Monoxide in n-Octacosane..................... 59

9. Solubility of Carbon Monoxide in n-Hexatriacontane................. 70

10. Solubility of Methane in n-Eicosane................................. 71

11. Solubility of Methane in n-Octacosane............................ 72

12. Solubility of Methane in n-Hexatriacontane......................... 73

13. Solubility of Ethane in n-Eicosane................................. 74

14. Solubility of Ethane in n-Octacosane................................ 75

15. Solubility of Ethane in n-Hexatriacontane........................... 76

16. Solubility of Ethylene in $\mathrm{n}$-Eicosane.................................. 77

17. Solubility of Ethylene in $\mathrm{n}$-Octacosane............................ 78

18. Solubility of Ethylene in $\mathrm{n}$-Hexatriacontane.......................... 79

19. Solubility of Carbon Dioxide in n-Eicosane............................ 80 
Figure

20. Solubility of Carbon Dioxide in n-Octacosane........................ 81

21. Solubility of Carbon Dioxide in n-Hexatriacontane.................... 82

22. Equilibrium Vapor Composition of Gas in Mixtures with n-Eicosane at $300^{\circ} \mathrm{C}$

23. Solubility of $\mathrm{H}_{2}$ in Synthesis Gas Mixtures of $\mathrm{H}_{2}+\mathrm{CO}$ in n-Octacosane at $200^{\circ} \mathrm{C}$.

24. Solubility of $\mathrm{H}_{2}$ in Synthesis Gas Mixtures of $\mathrm{H}_{2}+\mathrm{CO}$ in n-Octacosane at $300^{\circ} \mathrm{C}$.

25. $\mathrm{K}$-values of $\mathrm{H}_{2}$ in $\mathrm{H}_{2}+\mathrm{CO}$ Mixtures in n-Octacosane at $200^{\circ} \mathrm{C}$ 86

26. $\mathrm{K}$-values of $\mathrm{CO}$ in $\mathrm{H}_{2}+\mathrm{CO}$ Mixtures in n-Octacosane at $200^{\circ} \mathrm{C} \ldots \ldots .87$

27. K-values of $\mathrm{H}_{2}$ in $\mathrm{H}_{2}+\mathrm{CO}$ Mixtures in n-Octacosane at $300^{\circ} \mathrm{C} \ldots \ldots . .88$,

28. $\mathrm{K}$-values of $\mathrm{CO}$ in $\mathrm{H}_{2}+\mathrm{CO}$ Mixtures in n-Octacosane at $300^{\circ} \mathrm{C} \ldots \ldots 89$

29. Solubility of Hydrogen in Mobil Wax....................................90

30. Solubility of Carbon Monoxide in Mobil Wax............................91

31. Solubility of Methane in Mobil Wax................................... 92

32. Solubility of Ethane in Mobil Wax..................................... 93

33. Solubility of Carbon Dioxide in Mobil Wax................................94

34. Solubility of Hydrogen in SASOL Wax................................95

35. Solubility of Carbon Monoxide in SASOL Wax........................ 96

36. Solubility of Methane in SASOL Wax................................. 97

37. Solubility of Ethane in SASOL Wax................................... 98

38. Solubility of Ethylene in SASOL Wax................................. 99

39. Solubility of Carbon Dioxide in SASOL Wax...........................100 
Figure

40. Correlation with Krichevsky-Kasarnovsky Equation for n-Eicosane mixtures at $100^{\circ} \mathrm{C}$

41. Correlation with Krichevsky-Kasarnovsky Equation for $\mathrm{n}$-Eicosane mixtures at $200^{\circ} \mathrm{C}$

42. Correlation with Krichevsky-Kasarnovsky Equation for n-Eicosane mixtures at $300^{\circ} \mathrm{C}$

43. Correlation with Krichevsky-Kasarnovsky Equation for n-Octacosane mixtures at $100^{\circ} \mathrm{C}$

44. Correlation with Krichevsky-Kasarnovsky Equation for n-Octacosane mixtures at $200^{\circ} \mathrm{C}$

45. Correlation with Krichevsky-Kasarnovsky Equation for n-Octacosane mixtures at $300^{\circ} \mathrm{C}$

46. Correlation with Krichevsky-Kasarnovsky Equation for n-Hexatriacontane at $100^{\circ} \mathrm{C}$

47. Correlation with Krichevsky-Kasarnovsky Equation for $\mathrm{n}$-Hexatriacontane at $200^{\circ} \mathrm{C}$

48. Correlation with Krichevsky-Kasarnovsky Equation for $\mathrm{n}$-Hexatriacontane at $300^{\circ} \mathrm{C}$

49. Henry's Constants in n-Eicosane.............................. 110

50. Henry's Constants in n-Octacosane..............................

51. Henry's Constants in n-Hexatriacontane........................... 1.12

52. Plot of $A_{i j}$ vs Molecular Weight of n-Paraffins.................... 1.13

53. Plot of $A_{i j}$ vs Molecular Weight of n-Paraffins................... 114

54. Calculated Hydrogen Solubilities in n-Paraffins at $200^{\circ} \mathrm{C} \ldots \ldots \ldots . .125$

55. Calculated Hydrogen Solubilities in n-Paraffins at $300^{\circ} \mathrm{C} . . . . . . . .1 .15$ 
Figure

56. Calculated Carbon Monoxide Solubilities in n-Paraffins at $200^{\circ} \mathrm{C} . . .117$

57. Calculated Carbon Monoxide Solubilities in n-Paraffins at $300^{\circ} \mathrm{C} \ldots 118$

58. Calculated Carbon Dioxide Solubilities in n-Paraffins at $100^{\circ} \mathrm{C}$...... 119

59. Comparison of Calculated $\mathrm{H}_{2}$ Solubilities in Synthesis Gas Mixtures in n-Octacosane with Experimental Data at $200^{\circ} \mathrm{C} . . . . . . . . . .120$

60. Comparison of Calculated $\mathrm{H}_{2}$ Solubilities in Synthesis Gas Mixtures in n-Octacosane with Experimental Data at $300^{\circ} \mathrm{C} . . . . . . . . .121$

61. Comparison of Calculated CO Solubilities in Synthesis Gas Mixtures in n-Octacosane with Experimental Data at $200^{\circ} \mathrm{C} . . . \ldots \ldots . .122$

62. Comparison of Calculated CO Solubilities in Synthesis Gas Mixtures in n-Octacosane with Experimental Data at $300^{\circ} \mathrm{C}$

63. Prediction of Hydrogen Solubilities in Waxes at $200^{\circ}$................. 124

64. Prediction of Hydrogen Solubilities in Waxes at $300^{\circ} \ldots \ldots \ldots \ldots \ldots \ldots . . . \ldots 25$

65. Prediction of Carbon Monoxide Solubilities in Waxes at $200^{\circ} \mathrm{C} \ldots \ldots .125$

66. Prediction of Carbon Monoxide Solubilities in Waxes at $300^{\circ} \mathrm{C}$...... 1.27 


\section{SUMMARY AND CONCLUSION}

The objective of this research is to investigate the phase equilibrium behavior of synthesis gases and products in a Fischer-Tropsch slurry reactor. A semi-flow apparatus has been designed and constructed for this purpose. The apparatus provides contact for a flowing gas stream with a stationary liquid and is suitable for the determination of gas solubility in a molten wax of high melting point. The new apparatus has been tested with a mixture of carbon dioxide and toluene to verify attainment of equilibrium. The test data agree well with experimental results of $\mathrm{Ng}$ and Robinson from a static apparatus.

Measurements have been made for each of six gases (bydrogen, carbon monoxide, methane, ethane, ethylene, and carbon dioxide) in a heavy n-paraffin at temperatures from 100 to $300{ }^{\circ} \mathrm{C}$ and pressures 10 to $50 \mathrm{~atm}$. Three n-paraffin waxes: n-eicosane $\left(n-C_{20}\right)$, n-octacosane $\left(n-C_{28}\right)$, and $n$-hexatriacontane $\left(n-C_{36}\right)$, were studied in this work to model the industrial wax. Solubility of synthesis gas mixtures of $\mathrm{H}_{2}$ and $\mathrm{CO}$ in $\mathrm{n}-\mathrm{C}_{28}$ was also determined at two temperatures (200 and $300{ }^{\circ} \mathrm{C}$ ) for each of three gas compositions $(40.01,50.01$, and $66.64 \mathrm{~mol} \%$ of hydrogen). The measurements were extended to investigate the gas solubility in two industrial Fischer-Tropsch waxes: Mobil wax and SASOL wax.

The observed solubility increases in the order: $\mathrm{H}_{2}, \mathrm{CO}, \mathrm{CH}_{4}, \mathrm{CO}_{2}, \mathrm{C}_{2} \mathrm{H}_{4}$, $\mathrm{C}_{2} \mathrm{H}_{6}$, at a given temperature pressure, and in the same solvent, as shown by some typical result in the following table: 
Solubilities in $\mathrm{n}-\mathrm{C}_{36} \mathrm{H}_{74}$

at $200^{\circ} \mathrm{C}$ and $20 \mathrm{~atm}$
$\mathrm{H}_{2}$
CO
$\mathrm{CH}_{4}$
$\mathrm{CO}_{2}$
$\mathrm{C}_{2} \mathrm{H}_{4}$
$\mathrm{C}_{2} \mathrm{H}_{6}$
$x$, mole fraction
0.0476
0.0614
0.118
0.155
0.204
0.234

In mole fractions the solubility of a gas increases slightly with the molecular weight of the wax at the same temperatures and pressure. The increase is not as much as in proportions to the molecular weight with the result that the solubility in mass fractions slightly decreases with the molecular weight of the wax as shown by some typical result in the following table:

\section{Solubility of $\mathrm{H}_{2}$ in Various Waxes}

at $200^{\circ} \mathrm{C}$ and $20 \mathrm{~atm}$

$\begin{array}{llllc}\text { Solvent wax } & \mathrm{nC}_{20} & \mathrm{nC}_{28} & \mathrm{nC}_{36} & \text { Mobil wax }\left(\mathrm{nC}_{61}\right) \\ \text { x, mole fraction } & 0.0362 & 0.0402 & 0.0476 & 0.0661 \\ \text { w, mass fraction x } 10^{3} & 0.268 & 0.214 & 0.199 & 0.166\end{array}$

Solubility increases with increasing pressure for all the gases studied. At the temperatures of this investigation the lighter gases $\mathrm{H}_{2}$ and $\mathrm{CO}$ show increased solubility with increasing temperature, while the heavier gases $\mathrm{CO}_{2}$, ethane, and ethylene show decreased solubility with increasing temperature. The solubility of methane, the intermediate gas, changes little with temperature, and shows a shallow minimum at about $200^{\circ} \mathrm{C}$ or somewhat above. The observed variation with temperature agrees with the general pattern of the solubility of a gas to show a minimum, and for the temperature of minimum solubility to increase with the boiling point of the gas. 
Henry's constant and partial molal volume of the gas solute at infinite dilution are determined from the gas solubility data.

A correlation is developed from the experimental data in the form of an equation of state. The Soave equation of state is modified to fit the vapor pressure of the n-paraffins up to $n-C_{100}$. The Huron-Vidal mixing rule is introduced into the modified Soave equation to extend the equation to mixtures. The correlation is useful for the calculation of solubility of the gases $\left(\mathrm{H}_{2}, \mathrm{CO}, \mathrm{CH}_{4}, \mathrm{CO}_{2}, \mathrm{C}_{2} \mathrm{H}_{4}\right.$, and $\mathrm{C}_{2} \mathrm{H}_{6}$ ) in n-paraffins and industrial paraffin waxes. Calculations of the solubility of gas components in gas mixtures have been found to be as good as for the pure gases.

A computer program has been prepared to implement the correlation. Use of the program, list of the codes, input, output, and an example solubility calculation are described in the Appendix.

Solubility of the gases in solvents other than n-paraffins is of interest since some olefins, and oxygenates can also be present in Fischer-Tropsch waxes. Solubility can be a factor in the selection of solvent for slurry reactors of the future. Solubility data on gases of interest in solvents other than n-paraffins are scanty and must be measured to meet the needs. 


\section{Chapter 1. INTRODUCTION}

Continued development of Fischer-Tropsch synthesis in a slurry reactor has created a need for information on gas solubility in the slurry media. Satterfield and co-workers (Satterfield et al., 1982; Satterfield and Stenger, 1985; Stenger and Satterfield, 1985), Stern et al. (1983), and Albal et al. (1984) have studied the effect of liquid composition on the rate of reaction and selectivity of FischerTropsch synthesis in a slurry reactor, and concluded that the solubility of synthesis gases in the slurry was needed for interpretation of the synthesis reaction. The solubility information is also needed for the design and operation of synthesis processes.

Previous studies on the solubility of synthesis and product gases in heavy wax at conditions of temperature and pressure of the Fischer-Tropsch processes are limited. Albal and co-workers (1984) reported solubility data of synthesis gases $\left(\mathrm{H}_{2}, \mathrm{CO}\right)$ in Gulf wax at temperatures of 348-523K. Matsumoto and Satterfield (1985) investigated the solubility of hydrogen and carbon monoxide in three selected liquids (n-octacosane, phenanthrene, and fomblin YR), which they used in their Fischer-Tropsch synthesis studies. High temperature gas solubility in paraffin wax was measured by Peter and Weinert (1955).

In this work we designed and constructed a new apparatus for measurement of vapor-liquid equilibrium (VLE) for gas + slurry mixtures at conditions of FischerTropsch synthesis in slurry reactors. The apparatus, of semi-flow type, provides contact for a flowing gas stream with a stationary liquid and is suitable for the determination of gas solubility in a molten wax of high melting point. 
Measurements have been completed for 18 binary mixtures: hydrogen, carbon monoxide, methane, ethane, ethylene, and carbon dioxide in $n-C_{20}, n-C_{28}$, and in n- $\mathrm{C}_{36}$ at reactor conditions of Fischer-Tropsch synthesis, and for synthesis gas mixtures of $\mathrm{H}_{2}$ and $\mathrm{CO}$ in $\mathrm{n}-\mathrm{C}_{28}$ at three feed gas compositions (40.01, 50.01, and $66.64 \mathrm{~mol} \%$ of $\mathrm{H}_{2}$ ). Gas solubility has also been determined in Mobil wax and SASOL wax at temperatures of $200-300^{\circ} \mathrm{C}$ and pressures $10-50$ atm.

Henry's constant and partial molar volume at infinite dilution of the dissolved gas in n-paraffin solvent are determined from the solubility data. A correlation of synthesis and product gas solubility in n-paraffins and industrial paraffin waxes has been developed from a modified Soave equation of state incorporating Huron-Vidal mixing rules. 


\section{Chapter 2. EXPERIMENTAL APPARATUS AND PROCEDURE}

Figure 1 shows the scheme of the semi-flow apparatus, which consists of two main sections: the equilibration section and the sampling section. All parts exposed to high temperature and pressure are constructed of 316 stainless steel.

The heart of the equilibration section is the thermostated nitrogen bath in which two stainless steel cells are placed in series. The first cell serves as a presaturator, and the second, the equilibrium cell. The bath is a well insulated and regulated oven of $2.1 \mathrm{ft}^{3}$ internal volume. Nitrogen gas fills the bath in the course of experiments. Circulation of nitrogen in the bath is maintained by an electric fan mounted at the back of the bath. Two heating wires insulated in ceramic beads and controlled by rheostats are placed at the fan outlet to heat the bath. A secondary heater is connected to a temperature controller (Hailkainen Instrument Model 1053). The temperature sensor of the thermotrol is located in the vicinity of the equilibrium cell. The temperature uniformity in the bath was found to be within $0.5^{\circ} \mathrm{C}$ in the vicinity of the cells at bath temperature $100^{\circ} \mathrm{C}$, and $1^{\circ} \mathrm{C}$ at $300^{\circ} \mathrm{C}$. The uniformity should be improved when the apparatus is in operation with a gas stream flowing through the cells.

The temperature of the equilibrium cell is measured by a type $\mathbf{K}$ chromelalumel thermocouple inserted into the cell and calibrated to an accuracy of $\pm 0.1^{\circ} \mathrm{C}$. To ensure isothermal condition in the bath, a second thermocouple is placed outside the cell. Heating of the bath is controlled so that botb thermocouples give the same reading within their accuracy in the course of an experiment. A model CMM 0-750 psi Heise gauge is used to read the pressure with an accuracy of $\pm 0.1 \%$ of the 
maximum range.

Both cells are loaded at the beginning of a series of runs with about $500 \mathrm{~cm}^{3}$ of solvent. The bath is heated to the desired temperature before introducing the gas. Gas is supplied continuously to the system from the gas cylinder to maintain the pressure of interest and to promote mixing. The cells are packed with raschig rings, and the gas is sparged through the solvent in the cells. Equilibration requires about 20-40 minutes at the end of which the liquid composition attains a constant steady value. The gas flow rate is varied to test for constancy of gas composition when the gas composition is of interest.

\section{Sampling Procedure}

Liquid-phase effluent from the equilibrium cell is reduced in pressure and temperature before entering a trap for sampling. The heavy paraffin is condensed and retained as a solid in the trap at ambient conditions and later weighed with an analytical balance. The liberated gas from the condensate is determined volumetrically in a buret. For test mixtures of $\mathrm{CO}_{2}+$ toluene, toluene condensate is retained as liquid in the trap at ambient condition. Minor corrections for the quantities of $\mathrm{CO}_{2}$ dissolved in toluene and toluene vaporized into $\mathrm{CO}_{2}$ were made to the directly observed sample weight and gas volume. No such corrections are needed for the paraffin solubility experiments.

To prevent the entrainment of gas bubbles in the liquid samples and to maintain the system at constant pressure in the course of liquid-phase sampling, the gas stream from the presaturator is switched from the bottom of the equilibrium cell to a bypass at the top of the cell. 
The sampling system and procedure for determination of the content of volatilized wax in the vapor phase, when the volatility is appreciable, are similar to those described above for the liquid sample, except that a wet test meter was used in place of a buret to measure the gas as the gas volume is substantial.

In experiment for the solubility of synthesis gas mixtures $\left(\mathrm{H}_{2}+\mathrm{CO}\right)$ in $\mathrm{n}-\mathrm{C}_{28}$, the weight of solidified wax in the trap and the volume of liberated gas were determined by the same procedure described above for binary mixtures. The gas composition was determined with a Carle analytical gas chromatograph (GC) Model 111, equipped with a palladium tube for hydrogen transfer. The GC was calibrated with Matheson Primary Standard gas mixtures of $\mathrm{H}_{2}$ and $\mathrm{CO}$.

\section{$\underline{\text { Materials }}$}

The sources and purities of chemicals used in this work are as follows:

\begin{tabular}{lll} 
Chemical & Supplier & Purity \\
\hline $\mathrm{H}_{2}$ & Airco & $99.8^{+}$mole \% \\
$\mathrm{CO}$ & Matheson & $99.5^{+}$mole \% \\
$\mathrm{CH}_{4}$ & Matheson & $99^{+}$mole \% \\
$\mathrm{C}_{2} \mathrm{H}_{6}$ & Matheson & $99^{+}$mole \% \\
$\mathrm{C}_{2} \mathrm{H}_{4}$ & Matheson & $99.5^{+}$mole \% \\
$\mathrm{CO}_{2}$ & Matheson & $99.8^{+}$mole \% \\
$\mathrm{Toluene}_{\mathrm{n}}$ & Malinckrodt & $99 \mathrm{wt} \%$ \\
$\mathrm{n}-\mathrm{C}_{20}$ & Aldrich & $99 \mathrm{wt} \%$ \\
$\mathrm{n}-\mathrm{C}_{28}$ & Alfa & $99 \mathrm{wt} \%$ \\
$\mathrm{n}-\mathrm{C}_{36}$ & Alfa & $99 \mathrm{wt} \%$
\end{tabular}

The synthesis gas mixtures of $\mathrm{H}_{2}$ and $\mathrm{CO}$ were purchased from Matheson Gas Products (Primary Standard gas mixtures) at specified compositions. Mobil wax was supplied by Mobil Research and Development Corporation at Paulsboro, New 
Jersey. The wax was obtained from Run CT-256-7 of a two-stage Bench-Scale Unit. FIMS analysis gives a molar average molecular weight of 857 and weight average 1189 . Detailed results of the analysis were reported by Kuo (1985). The characterization of the SASOL (commercial Arge) wax was performed by UOP Inc. under DOE Contract No. DE-AC22-85PC80017. The carbon number range of the SASOL (Arge) wax, determined by GPC (Gel Permeation Chromatography), is from $C_{10}$ to $C_{250}$ with an average carbon number of 43 from GPC, and 47 from NMR analysis (UOP, 1986).

Possible thermal degradation of the n-paraffin in the experiments was examined by GC analysis of the collected paraffin sample and by comparing the repeated data points at the same conditions of temperature and pressure. No decomposed products were detected from GC at any of the experimental conditions of this work. The solubility data were reproducible within the experimental errors regardless of the age of $n$-paraffin wax in operation. 


\section{Chapter 3. EXPERIMENTAL RESULTS}

The apparatus has been tested with mixtures of carbon dioxide and toluene at 353K to verify attainment of equilibrium. As shown in Figures 2 and 3, the new data agree well with the experimental results of $\mathrm{Ng}$ and Robinson (1978) from a static apparatus. Further tests for the attainment of equilibrium have periodically been made by varying the gas flowrate over a factor of approximately 1.5 . All of the results reported in this work were found to be independent of the flowrate.

Gas solubility measurements have been completed for 18 binary mixtures: hydrogen, carbon monoxide, methane, ethane, ethylene, and carbon dioxide in $\mathrm{n}$ $\mathrm{C}_{20}, \mathrm{n}-\mathrm{C}_{28}$, and in $\mathrm{n}-\mathrm{C}_{36}$ at three temperatures $\left(100,200\right.$, and $\left.300^{\circ} \mathrm{C}\right)$. Along each isotherm, five pressures $(10,20,30,40$, and $50 \mathrm{~atm})$ were investigated for each system, except ethane binaries for which only four pressures $(10-40 \mathrm{~atm})$ were determined. The measurements at one temperature were made in the sequence of $10 \mathrm{~atm}, 30 \mathrm{~atm}, 50 \mathrm{~atm}, 40 \mathrm{~atm}$, and $20 \mathrm{~atm}$, to reveal any possible super or under saturation effects. No such effects have been observed for all the data reported in this work.

Tables 1-18 summarize the experimental results for each of the six gases in each of the three n-paraffins. At least four replicate samples were taken at an experimental condition of temperature and pressure. The multiple samples are generally reproducible to within $1.5 \%$ in the mol fraction of the gas component. The compositions reported in the tables are the average values of replicate samples. Figures 4-21 show the experimental solubility data, respectively, for 18 binary mixtures as a function of pressure at different temperatures. Individual sample 
compositions are shown in the figures as separate points when they can be distinguished. In Figure 19 we include the results of Gasem and Robinson (1985) at 50 and $100^{\circ} \mathrm{C}$ for $\mathrm{CO}_{2}+{ }_{\mathrm{n}}-\mathrm{C}_{20}$ mixtures. The agreement of their data and ours is reasonable with a maximum deviation of about $2.5 \%$, our data at higher pressures being consistently lower. Similarly, in Figures 20 and 21, we show the data of Gasem and Robinson (1985) at $100^{\circ} \mathrm{C}$ for $\mathrm{CO}_{2}$ in $\mathrm{n}-\mathrm{C}_{28}$ and in $\mathrm{n}-\mathrm{C}_{36}$, respectively. The agreement of their work and ours is excellent.

Gas solubility always increases with pressure at the conditions of this study. Hydrogen and carbon monoxide were found to be significantly more soluble at higher temperatures. The observed solubilities of carbon dioxide, ethane, and ethylene, on the other hand, decrease with increased temperature. The solubility of the intermediate gas, methane, in $\mathrm{n}-\mathrm{C}_{20}$ and in $\mathrm{n}-\mathrm{C}_{28}$ shows a shallow minimum in the range of $100-300^{\circ} \mathrm{C}$, but this transition is not observed in $\mathrm{n}-\mathrm{C}_{36}$, in which the methane solubility decreases with increase in temperature. The observed variation with temperature agrees with the general pattern of the solubility of a gas to show a minimum, and for the temperature of minimal solubility to increase with the boiling point of the gas. The decreasing solubility with increasing temperature at the lower temperatures is an indication of the dominant effect of the attractive forces between the solute and solvent molecules. However at the higher temperatures molecular collisions become more energetic and the repulsive forces between molecules dominate, resulting in increased solubility with increasing temperature, just like theoretically calculated solubility of hard core molecules.

The compositions of the saturated vapor phase have been determined for $\mathrm{H}_{2}$, 
$\mathrm{CH}_{4}, \mathrm{C}_{2} \mathrm{H}_{6}$, and $\mathrm{CO}_{2}$ in $\mathrm{n}-\mathrm{C}_{20}$ and in $\mathrm{n}-\mathrm{C}_{28}$ at higher temperatures. The experimental results are presented in the tables, while Figure 22 illustrates the results for each of the four gases in $\mathrm{n}-\mathrm{C}_{20}$ at $300^{\circ} \mathrm{C}$. The gas compositions in the saturated vapor phase increase with pressure but decrease with temperature at the experimental conditions of this study. The concentrations of $n-C_{20}$ and $n-C_{28}$ in the equilibrium gas are extremely low at the lower temperatures and are not explicitly reported in the tables. The equilibrium gas was found to be almost pure in the vapor phase at any of the states studied with $n-C_{36}$.

$\mathbf{K}$-values of the dissolved gas are reported in the tables at the conditions where the vapor-phase compositions have been measured. The $K$-values $(K \equiv y / x)$ were calculated from the experimental mole fractions in the liquid $(x)$ and mole fractions in the vapor $(y)$.

Equilibrium gas composition was not measured for $\mathrm{CO}$ and $\mathrm{C}_{2} \mathrm{H}_{4}$ in any of the n-paraffins. Only the solubility data are reported in the tables for these two gases.

Solubility of synthesis gas mixtures of $\mathrm{H}_{2}+\mathrm{CO}$ in $\mathrm{n}-\mathrm{C}_{28}$ was determined at three feed gas compositions: $40.01,50.01$, and $66.64 \mathrm{~mol} \%$ of $\mathrm{H}_{2}$, which are also the compositions of the equilibrium gas on a solvent-free basis. For each feed mixture, measurements were made at two temperatures, 200 and $300^{\circ} \mathrm{C}$, over the pressure range of 20-50 atm. The experimental results are reported in Table 19 and shown in Figures 23 and 24 for hydrogen solubility at different pressures. Figures 25 and 26 show $\mathrm{K}$-values of $\mathrm{H}_{2}$ and $\mathrm{CO}$, respectively, as a function of mol fraction of hydrogen $\mathrm{y}_{\mathrm{H}_{2}}$ in the gas mixture at $200^{\circ} \mathrm{C}$. The terminal points at $\mathrm{y}_{\mathrm{H}_{2}}=0$ and 
$y_{H_{2}}=1$ shown in the figures are taken from Tables 2 and 5. The $K$-values appear to be independent of gas composition within the experimental uncertainty. Similar results were found at $300^{\circ} \mathrm{C}$, as shown in Figures 27 and 28 .

The measurements are extended to solubility in industrial Fischer-Tropsch waxes. Two waxes were studied: a Mobil wax and a SASOL wax. Tables 20-24 present the experimental solubility data for each of five gases $\left(\mathrm{H}_{2}, \mathrm{CO}, \mathrm{CH}_{4}, \mathrm{C}_{2} \mathrm{H}_{6}\right.$, and $\mathrm{CO}_{2}$ ) in the Mobil wax. Figures 29-33 show the data as a function of pressure at different temperatures. Individual sample compositions at each condition of temperature and pressure are shown in the figures as separate points when they can be distinguished.

The Mobil wax contains a small amount of materials of relatively low molecular weight (Kuo, 1985). To minimize vaporization of these materials from the wax and the consequent alteration of its composition, we reduced the flowrate of the gas through the equilibrium cell to the minimum that could sustain the pressure. The solubility of the gases was observed to gradually decrease with the age of the wax to the extent of $3-5 \%$. The solubility data in Table IV are subject to an uncertainty of this magnitude.

The SASOL wax was found to change composition upon being kept in the solubility apparatus for a prolonged period during initial measurement at $300^{\circ} \mathrm{C}$. The lighter components of the wax vaporized, altering the composition of the wax, and the measured gas solubility changed up to $8 \%$ with time. Data that were observed to change were discarded. Only reproducible data are reported here. These were determined with fresh wax with gas flowing at a minimal rate to reduce 
vaporization loss of the lighter material from the wax.

Tables 25-30 reports the solubility data for each of six gases in the SASOL wax. Figures 34-39 show the data with respect to pressure at three temperatures. Only two temperatures were measured for $\mathrm{CO}_{2}$ and $\mathrm{C}_{2} \mathrm{H}_{4}$ in this wax. The solubility of the gases was again observed to gradually decrease with the age of the wax in operation. 
Chapter 4. CORRELATION WITH KRICHEVSKY-KASARNOVSKY EQUATION

Krichevsky-Kasarnovsky (K-K) equation (1935) is useful for representing solubilities of sparingly soluble gases up to moderate pressures. The equation is

$$
\ln \left(f_{i} / x_{i}\right)=\ln H_{i}+\bar{v}_{i}^{x}\left(p-p_{j}^{s}\right) / R T
$$

where $f_{i}$ stands for fugacity of solute $i$; $x_{i}$, mole fraction of $i$ in the liquid; $H_{i}$, Henry's constant of $i$; $\bar{v}_{i}^{x}$, the partial molar volume of the solute at infinite dilution; $p$, pressure; $p_{j}^{s}$, vapor pressure of the solvent; $R$, gas constant; and $T$, temperature. According to eq. 1 a linear relation should be obtained between $\ln \left(f_{i} / x_{i}\right)$ and $p$ for a given gas and solvent at a constant temperature. In Figures $40-48$ experimental data of this work are presented to show $\ln \left(f_{i} / x_{i}\right)$ as a function of $p$. The solute fugacity $f$ was calculated from the equilibrium gas data with the Lee and Kesler (1975) correlation of fugacity coefficients. For bydrogen the fugacity coefficient is assumed to be unity and $f_{i}=y_{i} p$. Straight lines are obtained in all the figures. The intercepts at $p=p_{j}^{s}$ of these plots give the Henry's constants according to the definition

$$
H_{i}=\lim _{x_{i} \rightarrow 0}\left(f_{i} / x_{i}\right)
$$

Henry's constant is useful for calculating gas solubility at low pressures. The slopes of the lines in Figures $40-48$ determine the partial molar volumes of the dissolved gas in the liquid phase. The values of the Henry's constant and the partial molar volume at infinite dilution so determined are reported in Table 31. Henry's constant is subject to an uncertainty of about $3 \%$, while the partial molar volume is less accurate with an uncertainty of about $10 \%$. No values of of $\overline{\mathrm{v}}^{\infty}$ are reported for 
hydrogen mixtures at $100^{\circ} \mathrm{C}$ as they are too small to be determined with any reasonable accuracy. The estimated standard deviations are listed in Table 31 for both $H$ and $\bar{v}^{x}$ at each condition. Figures $49-51$ show the results of the Henry's constant as a function of temperature. Included in the figures are also the data available in the literature for comparison. Excellent agreement with the data of Gasem and Robinson is obtained for $\mathrm{CO}_{2}$ mixtures. However, our results for $\mathrm{CH}_{4}$ and $\mathrm{C}_{2} \mathrm{H}_{6}$ in $\mathrm{n}-\mathrm{C}_{20}$ are different by about $5 \%$ from those of Chappelow and Prausnitz (1974). Poor agreement of our results with the data of Matsumoto and Satterfield is observed for $\mathrm{H}_{2}$ and $\mathrm{CO}$ in $\mathrm{n}-\mathrm{C}_{28}$. 


\section{Chapter 5. CORRELATION WITH EQUATION OF STATE}

Experimental gas solubility data in the model n-paraffin solvents were used to develop a correlation method in order to describe the solubility of the gases in $\mathrm{n}$ paraffins of a wide range of molecular weights. Several equations of state including the Soave, the Peng-Robinson, and the Cubic Chain-of-Rotators equations with different mixing rules have been examined. We report here the calculations from a modified Soave equation with new mixing rules.

Soave Equation of State. The Soave equation (1972) has been in wide use for engineering calculations. The equation is

$$
p=\frac{R T}{v-b}-\frac{\alpha a}{v(v+b)}
$$

where

$$
\begin{aligned}
& a=0.42747 \mathrm{R}^{2} \mathrm{~T}_{\mathrm{c}}^{2} / \mathrm{p}_{\mathrm{c}} \\
& \mathrm{b}=0.08664 \mathrm{RT}_{\mathrm{c}} / \mathrm{p}_{\mathrm{c}}
\end{aligned}
$$

Soave expressed $\alpha$ in terms of reduced temperature $T_{r}$ and acentric factor $\omega$. The original $\alpha$ expression was found to be inadequate for the heavy n-paraffins of interest in this work. A new expression was developed as follows,

$$
\alpha^{n}=1+m\left(1-T_{r}^{n}\right)
$$

where

$$
\mathrm{n}=0.5 \text { for } 142<\mathrm{M} \leq 268
$$

$$
=0.5685-2.552 \times 10^{-4} \mathrm{M} \text { for } \mathrm{M}>268
$$

The factor $\mathrm{m}$ in eq. 6 is correlated with the molecular weight $M$ of a n-paraffin in 
the following form:

$$
m=\sum_{i} B_{i} M^{i} \quad \text { for } i=0 \text { to } 4
$$

The coefficients of eq. 8 are

$$
\begin{aligned}
& B_{0}=0.47135 \\
& B_{1}=0.63325 \times 10^{-2} \\
& B_{2}=-0.78307 \times 10^{-5} \\
& B_{3}=0.44238 \times 10^{-8} \\
& B_{4}=-0.97365 \times 10^{-12}
\end{aligned}
$$

We use $M$ to replace $\omega$ for the convenient characterization of a n-paraffin. The critical temperature $T_{c}$ and critical pressure $P_{c}$ are also required in the equation. Literature values are available only up to $n-C_{20}$. A number of correlations proposed for $T_{c}$ and $P_{c}$ of $n$-paraffins can be used for extrapolation to beavier $n$ paraffins. As a result of a careful examination, we use in this work the Gasem and Robinson's method (1986), which requires the normal boiling point $T_{b}$ and carbon number $\mathrm{CN}$ according to

$$
Y=\left[\frac{C_{1}}{C_{4}}-\left(\frac{C_{1}}{C_{4}}-C_{3}^{1-C_{2}}\right) \exp \left\{-C_{4}(C N-1)\left(1-C_{2}\right)\right\}\right]^{\frac{1}{1-C_{2}}}
$$

where $Y$ represents either $p_{c}$ or $T_{b} / T_{c}$. The constants $C_{1}$ to $C_{4}$ are as follows:

$\begin{array}{ccc} & \mathrm{P}_{\mathrm{c}}, \text { bar } & \mathrm{T}_{\mathrm{b}} / \mathrm{T}_{\mathrm{c}} \\ \mathrm{C}_{1} & 8.0936 & 0.036175 \\ \mathrm{C}_{2} & 0.99288 & -0.47775 \\ \mathrm{C}_{3} & 54.555 & 0.58524 \\ \mathrm{C}_{4} & 8.0034 & 0.043358\end{array}$


The values of $T_{b}$ reported in API-44 Tables up to $n-C_{100}$ are used in our calculations. The calculated values of $T_{c}$ and $p_{c}$ for some of the heavy $n$-paraffins and the waxes studied in this work are given in Table 32.

The modified Soave equation of eq. $3-8$ represents vapor pressures of $n$ paraffins from $n-C_{10}$ to $n-C_{100}$ with an average absolute deviation (AAD) of $1.8 \%$. The vapor pressure values were taken from API-44 Tables.

Mixing Rules. Mixing rules for the equation parameters $a$ and $b$ in eq. 3 are needed in order for the equation to apply to mixtures. The classical van de Waals one-fluid mixing rules have been extensively used. We have found those simple rules to describe quite well the gas solubilities in a particular heavy n-paraffin. However, the values of interaction parameter $k_{a i j}$ can not be correlated in any form useful for general calculations. We have therefore developed a mixing rule from the Flory-Huggins expression for the excess Gibbs energy of polymer solutions.

Huron and Vidal (1979) obtained an expression for the excess Gibbs energy at infinite pressure, $g_{x}^{E}$, in terms of the equation parameters in the Soave equation:

$$
g_{x}^{E}=-\left[\frac{a}{b}-\sum_{i} \frac{a_{i}}{b_{i}} x_{i}\right] \ln 2
$$

The parameters $a$ and $b$ of a fluid mixture are related to the pure component $a_{i}$ and $b_{i}$ by the solution model that describes the $g_{E}$ of the mixture.

The Flory-Huggins model,

$$
\frac{g^{E}}{R T}=\frac{1}{2}\left(\sum_{i} x_{i} V_{i}\right)\left(\sum_{i} \sum_{j} A_{i j} \phi_{i} \phi_{j}\right)+\sum_{i} x_{i} \ell n\left(\phi_{i} / x_{i}\right)
$$

expresses the excess Gibbs energy of solutions in which the molecular sizes are significantly different. Solution of light gases in heavy paraffins is such a solution. 
$A_{i j}$ is the interaction parameter between species $i$ and $j . \quad A_{i i}=0$ for $i=j$ and $A_{i j}=A_{j i}$ for $i \neq j$. Substituting eq. 11 into eq. 10, we obtain

$$
\frac{a}{b}=\sum_{i} \frac{a_{i}}{b_{i}} x_{i}-\frac{R T}{l n 2}\left[\frac{1}{2}\left(\sum_{i} x_{i} V_{i}\right)\left(\sum_{i} \sum_{j} A_{i j} \phi_{i} \phi_{j}\right)+\sum_{i} x_{i} l n\left(\phi_{i} / x_{i}\right)\right]
$$

Since

$$
b=\sum_{i} x_{i} b_{i}
$$

both $\mathrm{a}$ and $\mathrm{b}$ of the mixture are obtained. In eq. $11, \mathrm{~V}_{\mathrm{i}}$ is the hard-core volume of the molecule $i$, and $\phi_{i}$ is defined as

$$
\phi_{i}=\frac{x_{i} V_{i}}{\sum_{j} x_{j} V_{j}}
$$

The values of hard-core volume are calculated in this work from Bondi's method (Bondi, 1968) and reported in Table 32 for all the substances studied in this work. The adjustable parameter $A_{i j}$ in eq. 11 is determined from fitting experimental solubility data.

Tables 33-35 present the values of $A_{i j}$ thus obtained for all the gases in $n-C_{20}, n-C_{28}$, and in $n-C_{36}$, respectively. The fitting of the experimental bubble pressure with these $A_{i j}$ values is good to about 3-6\% in average absolute deviation (AAD). The values of $A_{i j}$ were correlated in terms of molecular weight $M$ of $n$ paraffin:

$$
A_{i j}=A_{i j}^{x}\left[1-\exp \left(-M / M_{o}\right)\right]
$$

The coefficients of $M_{o}$ and $A_{i j}^{x}$ are given in Table 36 .

The solubilities calculated with the correlated $A_{i j}$ are in general comparable with the results from the optimal $A_{i j}$ as reported in Tables 35-37. Figures 52 and 
53 show the $A_{i j}$ values for the n-paraffins as a function of molecular weight. The $A_{i j}$ value at a constant temperature increases with molecular weight to approach an asymptotic value for the very heavy paraffins. We approximate this asymptotic value with that for $n-C_{36}$ for the purpose of simplification in calculations. All the calculations in this work for Mobil wax and the Sasol wax were consequently based on the $A_{i j}$ values for $n-C_{36}$.

Figures 54-57 compare the calculated gas sclubility with the experimental data for hydrogen mixtures and $\mathrm{CO}$ mixtures at 200 and $300^{\circ} \mathrm{C}$. Predicted solubilities for paraffins higher than those studied are shown in the figures to indicate the trend of variation of solubility with molecular weight. Figure 58 shows the comparison of the predicted $\mathrm{CO}_{2}$ solubility in $\mathrm{n}-\mathrm{C}_{44}$ with the data of Gasem and Robinson at $100^{\circ} \mathrm{C}$. Our data of $\mathrm{CO}_{2}$ in $\mathrm{n}-\mathrm{C}_{20}, \mathrm{n}-\mathrm{C}_{28}$, and in $\mathrm{n}-\mathrm{C}_{36}$ are also included. The agreement is reasonable.

Figures 59-62 show the calculated results in comparison with experimental data for synthesis gas mixtures of $\mathrm{H}_{2}$ and $\mathrm{CO}$ in n-octacosane at 200 and $300^{\circ} \mathrm{C}$. The interaction parameters $A_{i j}$ for $H_{2} / n-C_{28}$ and $C O / n-C_{28}$ are taken from Table 34, while $\mathrm{A}_{\mathrm{ij}}$ for $\mathrm{H}_{2} / \mathrm{CO}$ is assumed to be zero. The calculations are of a predictive nature. No experimental data on the synthesis gases were used in any way for adjustment of the equation. The predicted results appear to agree well with the data with a grand AAd of $2.8 \%$ in both $\mathrm{x}_{\mathrm{H}_{2}}$ and $\mathrm{x}_{\mathrm{CO}}$. Detailed comparison for each data point is reported in Table 37. Comparable results were obtained with the correlated $A_{i j}$ of eq. 15 . 
Extension to Wax. Kuo (1985) reported a molar average molecular weight of 857 , corresponding to a $a-C_{61}$ paraffin, for the Mobil wax of this study. In the calculations here the wax is treated as a $C_{61}$ n-paraffin. The values of $T_{c}, p_{c}$, and $V$ required in the modified Soave equation are calculated by the methods described in the last section and the values are reported in Table 32. The interaction parameters $A_{i j}$ for gas/wax at $200^{\circ} \mathrm{C}$ and $300^{\circ} \mathrm{C}$ are the same as gas $/ \mathrm{n}-\mathrm{C}_{36}$. The $\mathrm{A}_{\mathrm{ij}}$ values used in the calculations at $270^{\circ} \mathrm{C}$ are estimated by interpolation. The calculations are of a predictive nature. Experimental solubility data are not used for adjustment of the equation constants. The predicted results are compared with the data in Table 38 . The agreement is reasonable.

Figures 63-66 illustrate the calculated results for $\mathrm{H}_{2}$ and for $\mathrm{CO}$ in several waxes at 200 and $300^{\circ} \mathrm{C}$. Experimental data from this work and from Peter and Weinert (1955) are shown in the figures for comparison.

Table 39 compares the calculated results with experimental data for the SASOL wax. The average carbon number was reported by UOP Inc. to be 43 from GPC analysis and 47 from NMR. The SASOL wax was accordingly calculated as a $C_{43}$ n-paraffin $(M=605)$ in the modified Soave equation described above. The $A_{i j}$ values used are again taken from those of gas/n- $\mathrm{C}_{36}$. The comparison shows the prediction in reasonable agreement with the experimental data. We conclude that the modified Soave equation with the Huron-Vidal mixing rules is adequate for the calculations of gas solubilities in both Mobil and SASOL waxes. 
Table 1. Hydrogen $(\mathrm{H})+\mathrm{n}$-Eicosane VLE DATA

\begin{tabular}{lrccc} 
t, ${ }^{\circ} \mathrm{C}$ & p, atm & $\mathbf{x}_{\mathrm{H}}$ & $\mathbf{y}_{\mathrm{H}}$ & $\mathbf{K}_{\mathrm{H}}$ \\
\hline \multirow{2}{100.2}{} & 9.96 & 0.0113 & - & - \\
& 19.87 & 0.0229 & - & - \\
& 30.04 & 0.0348 & - & - \\
& 40.24 & 0.0464 & - & - \\
& 50.15 & 0.0563 & - & - \\
200.4 & 9.89 & 0.0182 & 0.9985 & 54.9 \\
& 19.90 & 0.0362 & 0.9992 & 27.6 \\
& 30.04 & 0.0539 & 0.9994 & 18.5 \\
& 39.83 & 0.0715 & 0.9995 & 14.0 \\
& 49.69 & 0.0866 & 0.9996 & 11.5 \\
300.1 & 9.81 & 0.0241 & 0.9617 & 39.8 \\
& 19.89 & 0.0501 & 0.9815 & 19.6 \\
& 29.93 & 0.0742 & 0.9878 & 13.3 \\
& 40.04 & 0.0965 & 0.9911 & 10.3 \\
& 49.99 & 0.117 & 0.9926 & 8.49
\end{tabular}


Table 2. Hydrogen $(\mathrm{H})+\mathrm{n}$-Octacosane VLE Data

\begin{tabular}{lrccc} 
t, ${ }^{\circ} \mathrm{C}$ & p, atm & $\mathbf{x}_{\mathrm{H}}$ & $\mathrm{y}_{\mathrm{H}}$ & $\mathrm{K}_{\mathrm{H}}$ \\
\hline \multirow{2}{*}{100.1} & 9.73 & 0.0149 & - & - \\
& 19.87 & 0.0296 & - & - \\
& 30.05 & 0.0428 & - & - \\
& 40.29 & 0.0597 & - & - \\
& 49.88 & 0.0715 & - & - \\
200.1 & 10.01 & 0.0206 & - & - \\
& 19.75 & 0.0402 & - & - \\
& 30.01 & 0.0608 & - & - \\
& 39.97 & 0.0807 & - & - \\
& 50.01 & 0.0993 & - & - \\
300.0 & 10.04 & 0.0288 & 0.9965 & 34.6 \\
& 19.83 & 0.0577 & 0.9982 & 17.3 \\
& 30.08 & 0.0850 & 0.9988 & 11.8 \\
& 40.03 & 0.110 & 0.9991 & 9.05 \\
& 50.04 & 0.136 & 0.9993 & 7.36
\end{tabular}


Table 3. Hydrogen $(\mathrm{H})+\mathrm{n}-$ Hexatriacontane VLE Data

\begin{tabular}{lllll}
$\mathfrak{t},{ }^{\circ} \mathrm{C}$ & p, atm & \multicolumn{1}{c}{$\mathbf{x}_{\mathrm{H}}$} & $\mathrm{y}_{\mathrm{H}}$ & $\mathbf{K}_{\mathrm{H}}$ \\
\hline \multirow{2}{*}{100.0} & 10.09 & 0.0154 & - & - \\
& 20.02 & 0.0323 & - & - \\
& 30.04 & 0.0487 & - & - \\
& 40.00 & 0.0641 & - & - \\
& 50.00 & 0.0809 & - & - \\
199.9 & 10.17 & 0.0227 & - & - \\
& 20.10 & 0.0476 & - & - \\
& 30.01 & 0.0704 & - & - \\
& 40.14 & 0.0926 & - & - \\
& 50.00 & 0.116 & - & - \\
300.0 & 10.09 & 0.0314 & - & - \\
& 20.12 & 0.0636 & - & - \\
& 30.10 & 0.0946 & - & - \\
& 40.04 & 0.123 & - & - \\
& 50.00 & 0.150 & - & -
\end{tabular}


Table 4. Carbon Monoxide + n-Eicosane VLE Data

\begin{tabular}{lrlll}
$t,{ }^{\circ} \mathrm{C}$ & p, atm & $\mathrm{x}_{\mathrm{CO}}$ & $\mathrm{y}_{\mathrm{CO}}$ & $\mathrm{K}_{\mathrm{CO}}$ \\
\hline 100.2 & 10.07 & 0.0187 & - & - \\
& 19.77 & 0.0380 & - & - \\
& 30.07 & 0.0571 & - & - \\
& 40.28 & 0.0761 & - & - \\
& 49.97 & 0.0922 & - & - \\
200.3 & 9.89 & 0.0230 & - & - \\
& 19.78 & 0.0469 & - & - \\
& 29.91 & 0.0708 & - & - \\
& 40.16 & 0.0949 & - & - \\
& 49.90 & 0.117 & - & - \\
300.0 & 9.94 & 0.0289 & - & - \\
& 19.84 & 0.0586 & - & - \\
& 29.89 & 0.0891 & - & - \\
& 40.25 & 0.117 & - & - \\
& 49.71 & 0.139 & - & -
\end{tabular}


Table 5. Carbon Monoxide + n-Octacosane VLE Data

\begin{tabular}{lrlll} 
t, ${ }^{\circ} \mathrm{C}$ & p, atm & \multicolumn{1}{c}{$\mathrm{x}_{\text {CO }}$} & $\mathrm{y}_{\mathrm{CO}}$ & $\mathrm{K}_{\mathrm{CO}}$ \\
\hline \multirow{2}{*}{100.3} & 9.95 & 0.0227 & - & - \\
& 19.73 & 0.0452 & - & - \\
& 29.98 & 0.0696 & - & - \\
& 40.21 & 0.0916 & - & - \\
& 50.03 & 0.112 & - & - \\
& & & & \\
200.0 & 10.07 & 0.0275 & - & - \\
& 19.65 & 0.0555 & - & - \\
& 30.14 & 0.0830 & - & - \\
& 39.92 & 0.109 & - & - \\
& 49.96 & 0.131 & - & \\
300.3 & 9.94 & 0.0336 & - & - \\
& 19.74 & 0.0669 & - & - \\
& 30.02 & 0.0993 & - & - \\
& 40.18 & 0.131 & - & - \\
& 50.06 & 0.156 & - & -
\end{tabular}


Table 6. Carbon Monoxide $+\mathrm{n}-$ Hexatriacontane VLE Data

\begin{tabular}{lllll}
$\mathrm{t},{ }^{\circ} \mathrm{C}$ & $\mathrm{p}$, atm & $\mathrm{x}_{\mathrm{CO}}$ & $\mathrm{y}_{\text {CO }}$ & $\mathrm{K}_{\text {CO }}$ \\
\hline \multirow{2}{*}{100.0} & 10.02 & 0.0257 & - & - \\
& 20.06 & 0.0514 & - & - \\
& 30.01 & 0.0764 & - & - \\
& 40.00 & 0.101 & - & - \\
& 49.91 & 0.123 & - & - \\
199.9 & 10.13 & 0.0307 & - & - \\
& 20.05 & 0.0614 & - & - \\
& 29.99 & 0.0917 & - & - \\
& 40.08 & 0.119 & - & - \\
& 50.14 & 0.146 & - & - \\
299.8 & 10.07 & 0.0382 & - & - \\
& 20.11 & 0.0754 & - & - \\
& 30.02 & 0.110 & - & - \\
& 40.03 & 0.144 & - & - \\
& 50.04 & 0.173 & - & -
\end{tabular}


Table 7. Methane (M) + n-Eicosane VLE Data

\begin{tabular}{lrlcc} 
t, ${ }^{\circ} \mathrm{C}$ & p, atm & \multicolumn{1}{c}{$\mathbf{x}_{\mathrm{M}}$} & \multicolumn{1}{c}{$\mathrm{y}_{\mathrm{M}}$} & $\mathrm{K}_{\mathrm{M}}$ \\
\hline \multirow{2}{*}{100.2} & 9.95 & 0.0472 & - & - \\
& 19.73 & 0.0903 & - & - \\
& 29.78 & 0.132 & - & - \\
& 39.84 & 0.172 & - & - \\
& 49.85 & 0.209 & - & - \\
& & & & \\
200.3 & 9.93 & 0.0427 & 0.9984 & 23.4 \\
& 19.69 & 0.0845 & 0.9990 & 11.8 \\
& 30.00 & 0.125 & 0.9992 & 7.97 \\
& 39.86 & 0.159 & 0.9993 & 6.27 \\
& 49.86 & 0.194 & 0.9993 & 5.16 \\
300.0 & 9.96 & 0.0440 & 0.9595 & 21.8 \\
& 19.89 & 0.0869 & 0.9772 & 11.2 \\
& 29.84 & 0.127 & 0.9830 & 7.76 \\
& 39.96 & 0.165 & 0.9858 & 5.98 \\
& 49.74 & 0.203 & 0.9876 & 4.86
\end{tabular}




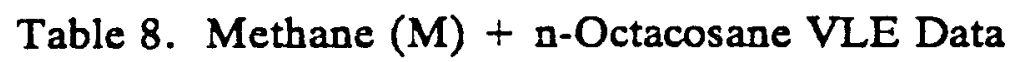

\begin{tabular}{lrlcc} 
t, ${ }^{\circ} \mathrm{C}$ & p, atm & \multicolumn{1}{c}{$\mathbf{x}_{\mathrm{M}}$} & $\mathrm{y}_{\mathrm{M}}$ & $\mathrm{K}_{\mathrm{M}}$ \\
\hline \multirow{2}{*}{100.1} & 9.77 & 0.0566 & - & - \\
& 19.90 & 0.113 & - & - \\
& 30.04 & 0.163 & - & - \\
& 40.19 & 0.204 & - & - \\
& 49.97 & 0.244 & - & - \\
200.2 & 9.78 & 0.0496 & - & - \\
& 19.81 & 0.100 & - & - \\
& 29.88 & 0.143 & - & - \\
& 40.36 & 0.189 & - & - \\
& 49.95 & 0.224 & - & - \\
300.1 & 9.48 & 0.0493 & 0.9962 & 20.2 \\
& 19.74 & 0.102 & 0.9979 & 9.78 \\
& 30.21 & 0.152 & 0.9985 & 6.57 \\
& 40.17 & 0.195 & 0.9986 & 5.12 \\
& 50.11 & 0.230 & 0.9986 & 4.34
\end{tabular}




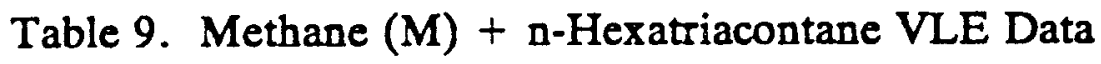

\begin{tabular}{lllll}
$\mathrm{t},{ }^{\circ} \mathrm{C}$ & $\mathrm{p}$, atm & \multicolumn{1}{c}{$\mathrm{x}_{\mathrm{M}}$} & $\mathrm{y}_{\mathrm{M}}$ & $\mathrm{K}_{\mathrm{M}}$ \\
\hline \multirow{2}{*}{100.0} & 10.11 & 0.0673 & - & - \\
& 20.07 & 0.130 & - & - \\
& 30.03 & 0.182 & - & - \\
& 40.06 & 0.230 & - & - \\
& 49.94 & 0.271 & - & - \\
200.0 & 10.06 & 0.0605 & - & - \\
& 20.02 & 0.118 & - & - \\
& 30.06 & 0.171 & - & - \\
& 39.93 & 0.211 & - & - \\
& 49.93 & 0.255 & - & - \\
300.0 & 10.08 & 0.0587 & - & - \\
& 20.12 & 0.114 & - & - \\
& 30.03 & 0.166 & - & - \\
& 40.08 & 0.212 & - & - \\
& 50.05 & 0.250 & - & -
\end{tabular}




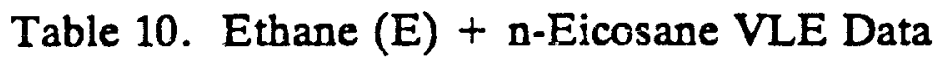

\begin{tabular}{lrlcc}
$t,{ }^{\circ} \mathrm{C}$ & p, atm & \multicolumn{1}{c}{$\mathbf{x}_{\mathrm{E}}$} & $\mathrm{y}_{E}$ & $\mathrm{~K}_{\mathrm{E}}$ \\
\hline \multirow{2}{*}{100.6} & 9.69 & 0.159 & - & - \\
& 19.91 & 0.284 & - & - \\
& 29.90 & 0.387 & - & - \\
& 39.91 & 0.463 & - & - \\
200.5 & 9.83 & 0.0960 & 0.9978 & 10.4 \\
& 19.86 & 0.175 & 0.9986 & 5.69 \\
& 29.99 & 0.251 & 0.9988 & 3.97 \\
& 40.18 & 0.314 & 0.9988 & 3.18 \\
299.7 & 9.83 & 0.0731 & 0.9499 & 13.0 \\
& 19.64 & 0.139 & 0.9682 & 6.97 \\
& 29.90 & 0.206 & 0.9768 & 4.75 \\
& 39.85 & 0.262 & 0.9810 & 3.74
\end{tabular}


Table 11. Ethane (E) + n-Octacosane VLE Data

\begin{tabular}{rrccc} 
t, ${ }^{\circ} \mathrm{C}$ & $\mathrm{p}$, atm & $\mathrm{x}_{\mathrm{E}}$ & $\mathrm{y}_{\mathrm{E}}$ & $\mathrm{K}_{\mathrm{E}}$ \\
\hline \multirow{2}{*}{100.1} & 9.76 & 0.180 & - & - \\
& 19.90 & 0.322 & - & - \\
& 28.82 & 0.425 & - & - \\
& 40.18 & 0.504 & - & - \\
& & & & \\
200.1 & 9.82 & 0.113 & - & - \\
& 19.87 & 0.207 & - & - \\
& 29.81 & 0.287 & - & - \\
& 37.46 & 0.335 & - & - \\
300.0 & 9.62 & 0.0840 & 0.9957 & 11.9 \\
& 19.76 & 0.166 & 0.9973 & 6.00 \\
& 29.83 & 0.236 & 0.9976 & 4.24 \\
& 39.87 & 0.297 & 0.9977 & 3.36
\end{tabular}




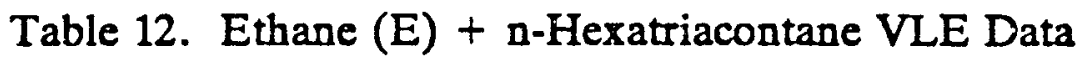

\begin{tabular}{ccccc} 
t, ${ }^{\circ} \mathrm{C}$ & p, atm & $\mathbf{x}_{\mathrm{E}}$ & $\mathrm{y}_{\mathrm{E}}$ & $\mathrm{K}_{\mathrm{E}}$ \\
\hline \multirow{2}{*}{100.0} & 10.07 & 0.212 & - & - \\
& 20.01 & 0.362 & - & - \\
& 30.00 & 0.466 & - & - \\
& 39.80 & 0.532 & - & - \\
199.9 & 10.01 & 0.126 & - & - \\
& 20.04 & 0.234 & - & - \\
& 29.98 & 0.321 & - & - \\
& 39.96 & 0.390 & - & - \\
299.9 & 10.06 & 0.101 & - & - \\
& 20.07 & 0.190 & - & - \\
& 30.00 & 0.263 & - & - \\
& 39.99 & 0.327 & - & -
\end{tabular}


Table 13. Ethylene Solubility in n-Eicosane

\begin{tabular}{lll} 
t, ${ }^{\circ} \mathrm{C}$ & p, atm & $\mathbf{x}_{\mathrm{C}_{2} \mathrm{H}_{4}}$ \\
\hline & & \\
100.1 & 10.10 & 0.122 \\
& 20.06 & 0.227 \\
& 29.94 & 0.319 \\
& 40.04 & 0.394 \\
& 49.95 & 0.454 \\
& & \\
200.0 & 10.18 & 0.0816 \\
& 20.03 & 0.154 \\
& 29.91 & 0.220 \\
& 39.96 & 0.280 \\
& 49.91 & 0.334 \\
300.0 & 10.12 & 0.0656 \\
& 20.06 & 0.131 \\
& 29.95 & 0.190 \\
& 39.98 & 0.244 \\
& 49.93 & 0.295
\end{tabular}


Table 14. Ethylene Solubility in n-Octacosane

$$
\begin{array}{rrl}
\text { t, }{ }^{\circ} \mathrm{C} & \mathrm{p}, \text { atm } & \mathrm{x}_{\mathrm{C}_{2} \mathrm{H}_{4}} \\
\hline & & \\
99.9 & 10.04 & 0.145 \\
& 20.06 & 0.254 \\
& 30.02 & 0.343 \\
& 39.98 & 0.421 \\
& 49.94 & 0.487 \\
& & \\
199.9 & 10.03 & 0.0974 \\
& 20.00 & 0.180 \\
& 29.97 & 0.250 \\
& 39.99 & 0.310 \\
& 49.89 & 0.368 \\
& & \\
299.9 & 9.99 & 0.0799 \\
& 20.07 & 0.150 \\
& 30.01 & 0.213 \\
& 40.00 & 0.272 \\
49.98 & 0.320
\end{array}
$$


Table 15. Ethylene Solubility in n-Hexatriacontane

\begin{tabular}{ccc} 
t, ${ }^{\circ} \mathrm{C}$ & p, atm & $\mathrm{x}_{\mathrm{C}_{2} \mathrm{H}_{4}}$ \\
\hline 100.1 & 10.13 & 0.172 \\
& 19.99 & 0.291 \\
& 29.97 & 0.392 \\
& 39.97 & 0.466 \\
& 49.93 & 0.526 \\
& & \\
199.9 & 10.09 & 0.112 \\
& 20.06 & 0.204 \\
& 29.95 & 0.279 \\
& 40.01 & 0.350 \\
& 49.97 & 0.402 \\
300.1 & 10.10 & 0.0932 \\
& 20.07 & 0.176 \\
& 29.99 & 0.241 \\
& 39.97 & 0.305 \\
& 50.01 & 0.360
\end{tabular}


Table 16. Carbon Dioxide (CD) + n-Eicosane VLE Data

\begin{tabular}{|c|c|c|c|c|}
\hline$t,{ }^{\circ} \mathrm{C}$ & p, atm & $\mathbf{x}_{C D}$ & $\mathrm{y}_{C D}$ & $\mathbf{K}_{C D}$ \\
\hline 50.1 & $\begin{array}{r}9.79 \\
19.89 \\
30.21 \\
39.97 \\
49.48\end{array}$ & $\begin{array}{l}0.114 \\
0.217 \\
0.305 \\
0.379 \\
0.446\end{array}$ & $\begin{array}{l}- \\
- \\
-\end{array}$ & $\begin{array}{l}- \\
- \\
-\end{array}$ \\
\hline 100.3 & $\begin{array}{l}10.04 \\
19.83 \\
30.02 \\
39.63 \\
49.90\end{array}$ & $\begin{array}{l}0.0842 \\
0.157 \\
0.228 \\
0.286 \\
0.342\end{array}$ & $\begin{array}{l}- \\
- \\
- \\
-\end{array}$ & $\begin{array}{l}- \\
- \\
-\end{array}$ \\
\hline 200.0 & $\begin{array}{r}9.85 \\
19.71 \\
30.24 \\
40.12 \\
49.50\end{array}$ & $\begin{array}{l}0.0593 \\
0.114 \\
0.170 \\
0.216 \\
0.259\end{array}$ & $\begin{array}{l}0.9979 \\
0.9989 \\
0.9991 \\
0.9992 \\
0.9992\end{array}$ & $\begin{array}{c}16.8 \\
8.75 \\
5.88 \\
4.62 \\
3.86\end{array}$ \\
\hline 300.2 & $\begin{array}{r}9.76 \\
19.93 \\
29.64 \\
40.64 \\
49.97\end{array}$ & $\begin{array}{l}0.0528 \\
0.104 \\
0.151 \\
0.201 \\
0.237\end{array}$ & $\begin{array}{l}0.9563 \\
0.9748 \\
0.9812 \\
0.9846 \\
0.9861\end{array}$ & $\begin{array}{r}18.11 \\
9.33 \\
6.52 \\
4.91 \\
4.17\end{array}$ \\
\hline
\end{tabular}


Table 17. Carbon Dioxide (CD) + n-Octacosane VLE Data

\begin{tabular}{rrlcc}
$\mathrm{t},{ }^{\circ} \mathrm{C}$ & $\mathrm{p}$, atm & \multicolumn{1}{c}{$\mathrm{x}_{\mathrm{CD}}$} & $\mathrm{y}_{\mathrm{CD}}$ & $\mathrm{K}_{\mathrm{CD}}$ \\
\hline \multirow{2}{*}{100.2} & 10.05 & 0.102 & - & - \\
& 20.14 & 0.184 & - & - \\
& 30.01 & 0.254 & - & - \\
& 40.15 & 0.324 & - & - \\
& 49.90 & 0.379 & - & - \\
200.3 & 9.87 & 0.0688 & - & - \\
& 20.04 & 0.135 & - & - \\
& 30.18 & 0.194 & - & - \\
& 39.89 & 0.247 & - & - \\
& 49.95 & 0.293 & - & - \\
300.3 & 9.81 & 0.0596 & 0.9957 & 16.7 \\
& 20.06 & 0.122 & 0.9975 & 8.16 \\
& 30.08 & 0.176 & 0.9981 & 5.69 \\
& 39.92 & 0.226 & 0.9983 & 4.42 \\
& 49.91 & 0.270 & 0.9983 & 3.69
\end{tabular}


Table 18. Carbon Dioxide (CD) $+\mathrm{n}-$ Hexatriacontane VLE Data

\begin{tabular}{ccccc}
$t,{ }^{\circ} \mathrm{C}$ & $\mathrm{p}$, atm & $\mathrm{x}_{\mathrm{CD}}$ & $\mathrm{y}_{\mathrm{CD}}$ & $\mathrm{K}_{\mathrm{CD}}$ \\
\hline \multirow{2}{100.0}{} & 10.08 & 0.110 & - & - \\
& 20.10 & 0.209 & - & - \\
& 29.97 & 0.289 & - & - \\
& 39.99 & 0.357 & - & - \\
& 49.99 & 0.415 & - & - \\
200.2 & 10.09 & 0.0803 & - & - \\
& 19.75 & 0.155 & - & - \\
& 29.95 & 0.220 & - & - \\
& 39.90 & 0.274 & - & - \\
& 49.92 & 0.324 & - & - \\
300.1 & 10.06 & 0.0706 & - & - \\
& 19.94 & 0.138 & - & - \\
& 29.97 & 0.198 & - & - \\
& 40.03 & 0.250 & - & - \\
& 50.00 & 0.297 & - & -
\end{tabular}


Table 19. Solubility Data of Synthesis Gas Mixtures in $\mathbf{n}-\mathrm{C}_{28}$

\begin{tabular}{llllll}
$t,{ }^{\circ} \mathbf{C}$ & $\mathbf{p}$, atm & $\mathbf{x}_{\mathrm{H}}$ & $\mathbf{x}_{\mathrm{CO}}$ & $\mathbf{K}_{\mathrm{H}}$ & $\mathbf{K}_{\mathrm{CO}}$ \\
\hline
\end{tabular}

Equilibrium Gas Composition: $40.01 \mathrm{~mol} \% \mathrm{H}_{2}, 59.99$ mol \% $\mathrm{CO}$

$\begin{array}{cccccc}200.1 & 19.74 & 0.0164 & 0.0326 & 24.5 & 18.4 \\ & 29.98 & 0.0247 & 0.0495 & 16.2 & 12.1 \\ & 40.23 & 0.0330 & 0.0657 & 12.1 & 9.14 \\ & 49.89 & 0.0401 & 0.0791 & 9.97 & 7.59 \\ 299.8 & 19.94 & 0.0227 & 0.0417 & 17.6 & 14.4 \\ & 30.01 & 0.0336 & 0.0618 & 11.9 & 9.71 \\ & 40.18 & 0.0442 & 0.0811 & 9.06 & 7.39 \\ & 49.81 & 0.0525 & 0.0964 & 7.63 & 6.23\end{array}$

Equilibrium Gas Composition: $50.01 \mathrm{~mol} \mathrm{\%} \mathrm{H}_{2}, 49.99 \mathrm{~mol} \% \mathrm{CO}$

$\begin{array}{cccccc}199.7 & 19.70 & 0.0201 & 0.0275 & 24.9 & 18.2 \\ & 29.94 & 0.0303 & 0.0407 & 16.5 & 12.3 \\ & 39.99 & 0.0415 & 0.0544 & 12.0 & 9.20 \\ & 49.90 & 0.0494 & 0.0653 & 10.1 & 7.66 \\ 300.0 & 19.79 & 0.0281 & 0.0340 & 17.8 & 14.7 \\ & 29.87 & 0.0412 & 0.0506 & 12.1 & 9.88 \\ & 40.17 & 0.0552 & 0.0661 & 9.06 & 7.56 \\ & 49.78 & 0.0656 & 0.0785 & 7.63 & 6.37\end{array}$

Equilibrium Gas Composition: $66.64 \mathrm{~mol} \% \mathrm{H}_{2}, 33.36 \mathrm{~mol} \% \mathrm{CO}$

$\begin{array}{cccccc}200.1 & 19.94 & 0.0275 & 0.0181 & 24.2 & 18.4 \\ & 30.14 & 0.0417 & 0.0276 & 16.0 & 12.1 \\ & 40.17 & 0.0543 & 0.0359 & 12.3 & 9.29 \\ & 49.91 & 0.0657 & 0.0434 & 10.1 & 7.69 \\ 299.9 & 19.93 & 0.0378 & 0.0228 & 17.6 & 14.6 \\ & 30.07 & 0.0562 & 0.0340 & 11.8 & 9.83 \\ & 40.22 & 0.0743 & 0.0448 & 8.97 & 7.44 \\ & 49.80 & 0.0887 & 0.0535 & 7.51 & 6.23\end{array}$


Table 20. Hydrogen Solubility in Mobil Wax

\begin{tabular}{ccc} 
t, ${ }^{\circ} \mathrm{C}$ & p, atm & $\begin{array}{c}\text { Solubility, } \\
\text { mole/Kg wax }\end{array}$ \\
\hline 200.1 & 10.23 & 0.0397 \\
& 20.12 & 0.0826 \\
& 30.05 & 0.129 \\
& 39.96 & 0.172 \\
& 50.09 & 0.219 \\
& & \\
270.1 & 17.02 & 0.0931 \\
& 27.26 & 0.152 \\
& 37.49 & 0.208 \\
& 47.67 & 0.269 \\
300.0 & 10.11 & 0.0519 \\
& 20.16 & 0.111 \\
& 30.05 & 0.170 \\
& 40.09 & 0.231 \\
& 50.04 & 0.289
\end{tabular}


Table 21. Carbon Monoxide Solubility in Mobil Wax

\begin{tabular}{ccc} 
t, ${ }^{\circ} \mathrm{C}$ & p, atm & $\begin{array}{c}\text { Solubility, } \\
\text { mole/Kg wa }\end{array}$ \\
\hline \multirow{2}{200.0}{} & 10.06 & 0.0522 \\
& 20.06 & 0.108 \\
& 29.98 & 0.165 \\
& 39.99 & 0.222 \\
& 49.94 & 0.285 \\
270.0 & 17.06 & 0.111 \\
& 27.31 & 0.179 \\
& 37.39 & 0.248 \\
& 47.57 & 0.316 \\
300.2 & 10.05 & 0.0619 \\
& 20.11 & 0.130 \\
& 29.99 & 0.197 \\
& 39.96 & 0.268 \\
& 49.63 & 0.336
\end{tabular}


Table 22. Methane Solubility in Mobil Wax

\begin{tabular}{lrl}
$\mathrm{t},{ }^{\circ} \mathrm{C}$ & p, atm & $\begin{array}{c}\text { Solubility, } \\
\text { mole/Kg wax }\end{array}$ \\
\hline 200.1 & 9.97 & 0.105 \\
& 20.12 & 0.226 \\
& 30.00 & 0.349 \\
& 40.04 & 0.475 \\
& 50.00 & 0.596 \\
270.0 & 17.08 & 0.183 \\
& 27.15 & 0.304 \\
& 37.47 & 0.423 \\
300.0 & 10.08 & 0.0954 \\
& 20.06 & 0.208 \\
& 29.99 & 0.317 \\
& 40.12 & 0.429 \\
& 50.00 & 0.550
\end{tabular}


Table 23. Ethane Solubility in Mobil Wax

\begin{tabular}{ccc}
$\mathrm{t},{ }^{\circ} \mathrm{C}$ & p, atm & $\begin{array}{c}\text { Solubility, } \\
\text { mole/Kg wax }\end{array}$ \\
\hline \multirow{2}{*}{200.0} & 10.00 & 0.223 \\
& 20.04 & 0.503 \\
& 29.93 & 0.774 \\
& 40.00 & 1.060 \\
270.1 & 17.00 & 0.325 \\
& 27.09 & 0.548 \\
& 37.40 & 0.789 \\
300.1 & 10.07 & 0.154 \\
& 20.13 & 0.350 \\
& 30.02 & 0.556 \\
& 39.95 & 0.760
\end{tabular}


Table 24. Carbon Dioxide Solubility in Mobil Wax

\begin{tabular}{ccc}
$t,{ }^{\circ} \mathrm{C}$ & p, atm & $\begin{array}{l}\text { Solubility, } \\
\text { mole/Kg wax }\end{array}$ \\
\hline 200.1 & 10.15 & 0.142 \\
& 20.03 & 0.309 \\
& 30.00 & 0.486 \\
& 39.95 & 0.657 \\
& 49.92 & 0.829 \\
270.0 & 16.92 & 0.232 \\
& 27.10 & 0.386 \\
& 37.22 & 0.556 \\
300.1 & 9.97 & 0.122 \\
& 20.11 & 0.271 \\
& 29.91 & 0.415 \\
& 39.95 & 0.553 \\
& 50.02 & 0.711
\end{tabular}


Table 25. Hydrogen Solubility in SASOL Wax

\begin{tabular}{lll}
$\mathbf{t},{ }^{\circ} \mathrm{C}$ & p, atm & $\begin{array}{l}\text { Solubility } \\
\text { mole/Kg wax }\end{array}$ \\
\hline \multirow{2}{*}{200.0} & 10.02 & 0.0432 \\
& 19.98 & 0.0923 \\
& 29.96 & 0.141 \\
& 40.01 & 0.191 \\
& 49.95 & 0.241 \\
260.1 & 10.04 & 0.0585 \\
& 20.02 & 0.119 \\
& 29.96 & 0.179 \\
& 39.98 & 0.240 \\
& 49.93 & 0.299 \\
300 & 10.07 & 0.0644 \\
& 19.99 & 0.0130 \\
& 29.94 & 0.202 \\
& 39.94 & 0.269 \\
& 49.96 & 0.334
\end{tabular}


Table 26. Carbon Monoxide Solubility in SASOL Wax

\begin{tabular}{ccc} 
t, ${ }^{\circ} \mathrm{C}$ & p, atm & $\begin{array}{l}\text { Solubility } \\
\text { mole/Kg wax }\end{array}$ \\
\hline \multirow{3}{*}{199.9} & 10.05 & 0.0701 \\
& 20.08 & 0.135 \\
& 29.95 & 0.198 \\
& 39.98 & 0.261 \\
& 50.00 & 0.322 \\
260.0 & 10.07 & 0.0774 \\
& 20.04 & 0.146 \\
& 30.05 & 0.225 \\
& 39.96 & 0.300 \\
& 49.96 & 0.373 \\
299.9 & 10.02 & 0.0810 \\
& 20.03 & 0.161 \\
& 30.03 & 0.242 \\
& 39.98 & 0.320 \\
& 50.01 & 0.400
\end{tabular}


Table 27. Methane Solubility in SASOL Wax

\begin{tabular}{rrr}
$\mathrm{t},{ }^{\circ} \mathrm{C}$ & p, atm & $\begin{array}{c}\text { Solubility, } \\
\text { mole/Kg wax }\end{array}$ \\
\hline 300.0 & 10.00 & 0.122 \\
& 20.02 & 0.246 \\
& 29.96 & 0.372 \\
& 39.94 & 0.497 \\
& 49.95 & 0.619 \\
259.9 & 10.02 & 0.119 \\
& 20.05 & 0.242 \\
& 29.99 & 0.364 \\
& 39.99 & 0.491 \\
& 50.02 & 0.613 \\
300.2 & 9.99 & 0.122 \\
& 20.03 & 0.247 \\
& 29.95 & 0.369 \\
& 39.94 & 0.497 \\
& 50.00 & 0.621
\end{tabular}


Table 28. Ethane Solubility in SASOL Wax

\begin{tabular}{ccc}
$\mathfrak{t},{ }^{\circ} \mathrm{C}$ & p, atm & $\begin{array}{l}\text { Solubility } \\
\text { mole/Kg wax }\end{array}$ \\
\hline \multirow{2}{*}{200.1} & 10.06 & 0.281 \\
& 20.06 & 0.553 \\
& 29.95 & 0.861 \\
& 39.97 & 1.17 \\
260.0 & 10.10 & 0.232 \\
& 20.05 & 0.470 \\
& 29.99 & 0.713 \\
& 40.00 & 0.985 \\
300.0 & 10.04 & 0.203 \\
& 20.03 & 0.409 \\
& 29.96 & 0.610 \\
& 39.97 & 0.874
\end{tabular}


Table 29. Ethylene Solubility in SASOL Wax

\begin{tabular}{ccc}
$\mathbf{t},{ }^{\circ} \mathrm{C}$ & $\mathbf{p}$, atm & $\begin{array}{l}\text { Solubility, } \\
\text { mole/Kg wax }\end{array}$ \\
\hline 200.0 & 10.03 & 0.237 \\
& 20.12 & 0.488 \\
& 29.99 & 0.742 \\
& 39.97 & 1.01 \\
& 49.90 & 1.25 \\
259.9 & 10.04 & 0.199 \\
& 20.12 & 0.415 \\
& 30.90 & 0.630 \\
& 40.04 & 0.848 \\
& 50.95 & 1.07
\end{tabular}


Table 30. Carbon Dioxide Solubility in SASOL Wax

\begin{tabular}{ccc}
$\mathbf{t},{ }^{\circ} \mathrm{C}$ & p, atm & $\begin{array}{l}\text { Solubility } \\
\text { mole/Kg }\end{array}$ \\
& & \\
\hline \multirow{2}{*}{260.1} & 20.06 & 0.305 \\
& 29.96 & 0.466 \\
& 39.99 & 0.626 \\
& 49.95 & 0.793 \\
300.2 & 19.97 & 0.305 \\
& 29.95 & 0.460 \\
& 39.95 & 0.625 \\
& 49.97 & 0.777
\end{tabular}


Table 31. Henry's Constants $(\mathrm{H})$ and Partial Molar Volumes at Infinite Dilution $\left(\bar{v}^{-x}\right)$ of Gases in $n-C_{20}, n-C_{28}$, and $n-C_{36}$

\begin{tabular}{|c|c|c|c|c|c|c|}
\hline & \multicolumn{2}{|c|}{$100^{\circ} \mathrm{C}$} & \multicolumn{2}{|c|}{$200^{\circ} \mathrm{C}$} & \multicolumn{2}{|c|}{$300^{\circ} \mathrm{C}$} \\
\hline Solvent & $\begin{array}{c}\mathrm{H} \\
\text { atm }\end{array}$ & $\begin{array}{c}\overline{\mathbf{v}}^{-\infty}, \\
\mathrm{mL} / \mathrm{mole}\end{array}$ & $\begin{array}{c}\mathrm{H}, \\
\text { atm }\end{array}$ & $\begin{array}{c}\bar{v}^{\infty}, \\
\text { mL/mole }\end{array}$ & $\begin{array}{r}\mathrm{H}, \\
\text { atm }\end{array}$ & $\begin{array}{c}\bar{v}^{\infty}, \\
\text { mL/mole }\end{array}$ \\
\hline $\begin{array}{l}-C_{20} \\
-C_{28} \\
-C_{36}\end{array}$ & $\begin{array}{c}868(12)^{\bullet} \\
653(15) \\
619(6)\end{array}$ & $* *$ & $\begin{array}{c}\text { aydrogen } \\
536(4) \\
482(2) \\
432(5)\end{array}$ & $\begin{array}{r}33(9) \\
32(5) \\
34(11)\end{array}$ & $\begin{array}{l}377(5) \\
337(5) \\
313(5)\end{array}$ & $\begin{array}{r}103(19) \\
80(19) \\
47(21)\end{array}$ \\
\hline \multicolumn{7}{|c|}{ carbon monoxide } \\
\hline $\begin{array}{l}C_{20} \\
-C_{28} \\
-C_{36}\end{array}$ & $\begin{array}{r}526(11) \\
431(6) \\
383(3)\end{array}$ & $\begin{array}{l}15(9) \\
21(9) \\
35(8)\end{array}$ & $\begin{array}{l}425(4) \\
354(8) \\
321(5)\end{array}$ & $\begin{array}{r}34(6) \\
62(22) \\
88(13)\end{array}$ & $\begin{array}{l}334(7) \\
286(4) \\
256(2)\end{array}$ & $\begin{array}{r}63(23) \\
116(15) \\
124(14)\end{array}$ \\
\hline $\begin{array}{l}C_{20} \\
C_{28} \\
C_{36}\end{array}$ & $\begin{array}{l}205(1) \\
163(2) \\
141(2)\end{array}$ & $\begin{array}{r}75(3) \\
125(13) \\
142(9)\end{array}$ & $\begin{array}{c}\text { methane } \\
223(3) \\
189(2) \\
157(3)\end{array}$ & $\begin{array}{l}119(16) \\
141(14) \\
166(19)\end{array}$ & $\begin{array}{l}212(2) \\
183(3) \\
164(2)\end{array}$ & $\begin{array}{l}139(11) \\
152(24) \\
180(19)\end{array}$ \\
\hline $\begin{array}{l}\mathrm{C}_{20} \\
-\mathrm{C}_{28} \\
\mathrm{C}_{36}\end{array}$ & $\begin{array}{r}114(1) \\
94(2) \\
84(1)\end{array}$ & $\begin{array}{c}\text { ca } \\
82(5) \\
115(6) \\
143(7)\end{array}$ & $\begin{array}{c}\text { bon dioxi } \\
160(1) \\
137(1) \\
117(2)\end{array}$ & $\begin{array}{r} \\
104(4) \\
133(8) \\
175(20)\end{array}$ & $\begin{array}{l}171(1) \\
156(2) \\
134(2)\end{array}$ & $\begin{array}{r}167(9) \\
169(10) \\
189(20)\end{array}$ \\
\hline $\begin{array}{l}a-C_{20} \\
a-C_{28} \\
a-C_{36}\end{array}$ & $\begin{array}{l}55(1) \\
48(1) \\
41(1)\end{array}$ & $\begin{array}{r}237(28) \\
274(22) \\
348(8)\end{array}$ & $\begin{array}{c}\text { ethane } \\
96(2) \\
80(1) \\
73(1)\end{array}$ & $\begin{array}{l}228(25) \\
289(15) \\
306(19)\end{array}$ & $\begin{array}{r}123(2) \\
107(1) \\
93(1)\end{array}$ & $\begin{array}{l}215(21) \\
261(19) \\
298(13)\end{array}$ \\
\hline $\begin{array}{l}\mathrm{n}-\mathrm{C}_{20} \\
\mathrm{n}-\mathrm{C}_{28} \\
\mathrm{n}-\mathrm{C}_{36}\end{array}$ & $\begin{array}{l}77(1) \\
64(1) \\
53(1)\end{array}$ & $\begin{array}{r}129(6) \\
207(19) \\
274(13)\end{array}$ & $\begin{array}{c}\text { ethylene } \\
119(1) \\
96(1) \\
84(1)\end{array}$ & $\begin{array}{r}139(3) \\
236(10) \\
271(10)\end{array}$ & $\begin{array}{l}143(1) \\
119(1) \\
101(1)\end{array}$ & $\begin{array}{r}144(2) \\
236(8) \\
282(16)\end{array}$ \\
\hline
\end{tabular}

- Numbers in parentheses are standard deviations.

** too small to be determined with any reasonable accuracy. 
Table 32. Physical Properties and van der Waal's Volumes of Substances

\begin{tabular}{lccrc} 
Substance & $\mathrm{T}_{\mathrm{c}}, \mathrm{K}$ & $\mathrm{P}_{\mathrm{c}}$, atm & $\mathrm{V}_{\mathrm{i}}, \mathrm{mL} / \mathrm{mole}$ & $\omega$ \\
\hline $\mathrm{He}$ & 5.19 & 2.24 & 4.80 & -0.387 \\
$\mathrm{H}_{2}$ & 33.2 & 12.8 & 10.51 & -0.22 \\
$\mathrm{CO}$ & 132.9 & 34.5 & 13.01 & 0.049 \\
$\mathrm{CO}_{2}$ & 304.2 & 72.8 & 19.68 & 0.225 \\
$\mathrm{CH}_{4}$ & 190.6 & 45.4 & 17.09 & 0.008 \\
$\mathrm{C}_{2} \mathrm{H}_{4}$ & 282.4 & 49.7 & 23.88 & 0.085 \\
$\mathrm{C}_{2} \mathrm{H}_{6}$ & 305.4 & 48.2 & 27.34 & 0.098 \\
$\mathrm{n}-\mathrm{C}_{10}$ & 617.1 & 20.7 & 109.18 & - \\
$\mathrm{n}-\mathrm{C}_{16}$ & 719.8 & 13.6 & 170.56 & - \\
$\mathrm{n}-\mathrm{C}_{20}$ & 768.8 & 11.0 & 211.48 & - \\
$\mathrm{n}-\mathrm{C}_{28}$ & 843.7 & 8.15 & 293.32 & - \\
$\mathrm{n}-\mathrm{C}_{36}$ & 900.8 & 6.73 & 375.16 & - \\
$\mathrm{n}-\mathrm{C}_{43}$ & 941.5 & 6.03 & 446.77 & - \\
$\mathrm{n}-\mathrm{C}_{44}$ & 946.7 & 5.96 & 457.00 & - \\
$\mathrm{n}-\mathrm{C}_{60}$ & 1016.6 & 5.25 & 620.68 & - \\
$\mathrm{n}-\mathrm{C}_{61}$ & 1020.3 & 5.23 & 630.91 & - \\
$\mathrm{n}-\mathrm{C}_{100}$ & 1116.8 & 4.87 & 1029.88 & -
\end{tabular}


Table 33. Comparison of the Modified Soave Equation Calculated Gas Solubilities in n-Eicosane with Experimental Data

Optimal $\mathbf{A}_{\mathrm{ij}} \quad$ Correlated $\mathbf{A}_{\mathrm{ij}}$

\begin{tabular}{|c|c|c|c|c|c|c|c|c|c|c|}
\hline Gas & $\stackrel{t,}{0^{\circ}}$ & Data & $\mathbf{A}_{i j}$ & Devi & tions ir & $p, \%$ & $A_{i j}$ & Dev & tions in & $\begin{array}{l}\% \% \\
\text { BIAS }\end{array}$ \\
\hline$\overline{\mathrm{H}_{2}}$ & $\begin{array}{l}100 \\
200\end{array}$ & $\begin{array}{l}5 \\
5 \\
5\end{array}$ & $\begin{array}{l}0.238 \\
0.217 \\
0 ? 216\end{array}$ & $\begin{array}{l}3.3 \\
3.0 \\
3.4\end{array}$ & $\begin{array}{l}2.9 \\
2.7 \\
2.8\end{array}$ & & $\begin{array}{l}0.235 \\
0.219 \\
0.214\end{array}$ & $\begin{array}{l}4.9 \\
3.7 \\
3.6\end{array}$ & $\begin{array}{l}3.8 \\
3.0 \\
2.6\end{array}$ & $\begin{array}{r}-3.8 \\
2.0 \\
-16\end{array}$ \\
\hline
\end{tabular}

$\begin{array}{rrrrrrrrrrr}\text { CO } \quad 100 & 5 & 0.160 & 4.3 & 3.3 & -0.9 & 0.160 & 4.3 & 3.3 & -0.9 \\ & 200 & 5 & 0.148 & 5.3 & 4.4 & -0.5 & 0.149 & 5.4 & 4.7 & 0.9 \\ & 300 & 5 & 0.150 & 5.4 & 4.7 & -0.6 & 0.148 & 5.8 & 4.2 & -2.8\end{array}$

$\begin{array}{rrrrrrrrrrr}\mathrm{CH}_{4} & 100 & 5 & 0.0879 & 3.2 & 2.8 & -0.2 & 0.0882 & 3.2 & 2.7 & 0.3 \\ & 200 & 5 & 0.0863 & 2.8 & 2.4 & 0.0 & 0.0863 & 2.8 & 2.4 & 0.0 \\ & 300 & 5 & 0.0900 & 3.2 & 2.7 & -0.2 & 0.0898 & 3.2 & 2.8 & -0.7\end{array}$

$\begin{array}{rrrrrrrrrrr}\mathrm{CO}_{2} & 100 & 5 & 0.0969 & 3.9 & 34 & -0.3 & 0.0978 & 4.4 & 3.9 & 1.6 \\ & 200 & 5 & 0.0838 & 3.0 & 2.7 & -0.2 & 0.0848 & 3.5 & 3.1 & 1.5 \\ & 300 & 5 & 0.0806 & 2.0 & 1.9 & -0.1 & 0.0806 & 2.0 & 1.9 & -0.1\end{array}$

$\begin{array}{rrrrrrrrrrr}\mathrm{C}_{2} \mathrm{H}_{6} & 100 & 4 & 0.0385 & 0.8 & 0.8 & 0.0 & 0.0392 & 2.0 & 1.8 & 1.8 \\ & 200 & 4 & 0.0388 & 1.1 & 0.9 & 0.0 & 0.0386 & 1.1 & 0.7 & -0.3 \\ & 300 & 4 & 0.0419 & 1.3 & 1.2 & 0.0 & 0.0410 & 2.4 & 2.0 & -2.0\end{array}$

$\begin{array}{llllllllllr}\mathrm{C}_{2} \mathrm{H}_{4} & 100 & 5 & 0.0475 & 4.1 & 3.7 & -0.2 & 0.0491 & 5.6 & 4.9 & 3.5 \\ & 200 & 5 & 0.0474 & 3.3 & 2.7 & -0.2 & 0.0482 & 3.7 & 3.2 & 1.5 \\ & 300 & 5 & 0.0520 & 4.7 & 3.8 & -0.2 & 0.0509 & 5.2 & 3.8 & -2.5\end{array}$


Table 34. Comparison of the Modified Soave Equation Calculated Gas Solubilities in n-Octacosane with Experimental Data

Optimal $\mathbf{A}_{\mathrm{ij}} \quad$ Correlated $\mathbf{A}_{\mathrm{ij}}$

\begin{tabular}{|c|c|c|c|c|c|c|c|c|c|c|}
\hline \multirow[t]{2}{*}{ Gas } & \multirow{2}{*}{${ }^{t} \mathrm{C}$} & \multirow{2}{*}{$\begin{array}{l}\text { Data } \\
\text { Pts }\end{array}$} & \multirow{2}{*}{$\underset{\text { mole/ml }}{\mathbf{A}_{\mathrm{ij}}}$} & \multicolumn{3}{|c|}{ Deviations in $\mathrm{p}, \%$} & \multirow{2}{*}{$\underset{\mathrm{mole} / \mathrm{ml}}{\mathrm{A}_{\mathrm{ij}}}$} & \multicolumn{3}{|c|}{ Deviations in $\mathrm{p}, \%$} \\
\hline & & & & RMS & AAD & BIAS & & RMS & AAD & $\frac{\text { BIAS }}{50}$ \\
\hline \multirow[t]{2}{*}{$\mathrm{H}_{2}$} & 100 & 5 & 0.246 & 2.9 & 2.7 & -0.1 & 0.251 & 6.6 & 5.8 & $\begin{array}{r}5.8 \\
-0.6\end{array}$ \\
\hline & $\begin{array}{l}200 \\
300\end{array}$ & $\begin{array}{l}5 \\
5\end{array}$ & $\begin{array}{l}0.235 \\
0.228\end{array}$ & $\begin{array}{l}4.1 \\
4.7\end{array}$ & $\begin{array}{l}3.7 \\
3.7\end{array}$ & $\begin{array}{l}-0.6 \\
-0.4\end{array}$ & $\begin{array}{l}0.235 \\
0.230\end{array}$ & $\begin{array}{l}4.1 \\
5.2\end{array}$ & $\begin{array}{l}3.7 \\
4.3\end{array}$ & $\begin{array}{r}-0.6 \\
1.9\end{array}$ \\
\hline \multirow[t]{3}{*}{ CO } & 100 & 5 & 0.171 & 4.8 & 4.3 & -0.4 & 0.173 & 5.6 & 5.1 & 2.6 \\
\hline & 200 & 5 & 0.160 & 4.6 & 3.6 & -0.3 & 0.162 & 4.9 & 4.3 & 1.6 \\
\hline & 300 & 5 & 0.160 & 4.4 & 3.8 & 0.0 & 0.160 & 4.4 & 3.8 & 0.0 \\
\hline \multirow[t]{3}{*}{$\mathrm{CH}_{4}$} & 100 & 5 & 0.0956 & 2.9 & 2.3 & -0.2 & 0.0962 & 3.1 & 2.7 & 0.8 \\
\hline & 200 & 5 & 0.0950 & 3.9 & 3.2 & -0.3 & 0.0941 & 4.0 & 3.4 & -1.5 \\
\hline & 300 & 5 & 0.0965 & 4.5 & 3.9 & -0.1 & 0.0979 & 5.1 & 4.5 & 2.1 \\
\hline \multirow[t]{3}{*}{$\mathrm{CO}_{2}$} & 100 & 5 & 0.106 & 3.8 & 3.6 & 0.0 & 0.106 & 3.8 & 3.6 & 0.0 \\
\hline & 200 & 5 & 0.0919 & 4.1 & 3.5 & -0.3 & 0.0917 & 4.1 & 3.4 & -0.8 \\
\hline & 300 & 5 & 0.0873 & 5.2 & 4.2 & -0.4 & 0.0872 & 5.2 & 4.2 & -0.6 \\
\hline \multirow[t]{3}{*}{$\mathrm{C}_{2} \mathrm{H}_{6}$} & 100 & 4 & 0.0446 & 2.7 & 2.2 & -0.1 & 0.0443 & 2.8 & 2.5 & -0.9 \\
\hline & 200 & 4 & 0.0438 & 0.8 & 0.7 & 0.0 & 0.0436 & 0.9 & 0.9 & -0.5 \\
\hline & 300 & 4 & 0.0460 & 2.9 & 2.3 & -0.1 & 0.0463 & 2.9 & 2.5 & 0.4 \\
\hline \multirow[t]{3}{*}{$\mathrm{C}_{2} \mathrm{H}_{4}$} & 100 & 5 & 0.0557 & 3.3 & 3.0 & -0.3 & 0.0544 & 4.6 & 4.1 & -3.4 \\
\hline & 200 & 5 & 0.0538 & 2.0 & 1.5 & 0.0 & 0.0535 & 2.1 & 1.8 & -0.7 \\
\hline & 300 & 5 & 0.0566 & 2.6 & 2.4 & -0.1 & 0.0565 & 2.6 & 2.4 & -0.3 \\
\hline
\end{tabular}


Table 35. Comparison of the Modified Soave Equation Calculated Gas Solubilities in n-Hexatriacontane with Experimental Data

Optimal $\mathbf{A}_{\mathrm{ij}} \quad$ Correlated $\mathbf{A}_{\mathrm{ij}}$

\begin{tabular}{lcccccccccr}
\multirow{2}{*}{ Gas } & $\mathbf{t}$, & Data & \multicolumn{2}{c}{$\mathbf{A}_{\mathrm{ij}}$} & \multicolumn{2}{c}{ Deviations in p, \% } & \multicolumn{2}{c}{$\mathrm{A}_{\mathrm{ij}}$} & \multicolumn{2}{c}{ Deviations in p, \% } \\
& ${ }^{\circ} \mathbf{C}$ & Pts & mole/ml & RMS & AAD & BIAS & mole/ml & RMS & AAD & BIAS \\
\hline $\mathrm{H}_{2}$ & 100 & 5 & 0.260 & 6.1 & 4.9 & -0.4 & 0.258 & 6.3 & 4.7 & -2.0 \\
& 200 & 5 & 0.243 & 7.0 & 5.3 & -0.8 & 0.241 & 6.9 & 5.2 & -2.4 \\
& 300 & 5 & 0.237 & 6.2 & 5.2 & -0.7 & 0.236 & 6.2 & 5.1 & -1.4
\end{tabular}

$\begin{array}{lllllllllll}\text { CO } & 100 & 5 & 0.181 & 4.6 & 3.9 & -0.2 & 0.179 & 4.8 & 4.0 & -2.0 \\ & 200 & 5 & 0.170 & 5.0 & 4.3 & -0.4 & 0.168 & 5.6 & 4.1 & -3.0 \\ & 300 & 5 & 0.166 & 4.7 & 4.1 & -0.4 & 0.166 & 4.7 & 4.1 & -0.4\end{array}$

$\begin{array}{lllllllllll}\mathrm{CH}_{4} & 100 & 5 & 0.101 & 3.1 & 2.4 & -0.2 & 0.100 & 3.5 & 2.5 & -1.9 \\ & 200 & 5 & 0.0981 & 3.6 & 2.9 & -0.2 & 0.0978 & 3.5 & 2.7 & -0.6 \\ & 300 & 5 & 0.102 & 4.6 & 4.0 & -0.6 & 0.102 & 4.6 & 4.0 & -0.6\end{array}$

$\begin{array}{lllllllllll}\mathrm{CO}_{2} & 100 & 5 & 0.110 & 5.7 & 4.7 & -0.6 & 0.109 & 6.1 & 4.8 & -2.7 \\ & 200 & 5 & 0.0960 & 4.7 & 3.6 & -0.3 & 0.0947 & 4.9 & 3.5 & -2.6\end{array}$

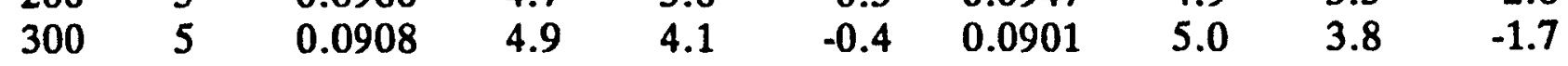

$\begin{array}{lllllllllll}\mathrm{C}_{2} \mathrm{H}_{6} & 100 & 4 & 0.0475 & 2.0 & 1.9 & -0.1 & 0.0470 & 2.4 & 1.8 & -1.5 \\ & 200 & 4 & 0.0468 & 3.4 & 2.8 & -0.2 & 0.0463 & 3.7 & 2.8 & -1.2 \\ & 300 & 4 & 0.0483 & 2.8 & 2.2 & -0.1 & 0.0492 & 3.6 & 3.3 & 2.2\end{array}$

$\begin{array}{lllllllllll}\mathrm{C}_{2} \mathrm{H}_{4} & 100 & 5 & 0.0577 & 2.6 & 2.4 & 0.0 & 0.0571 & 2.9 & 2.3 & -1.5\end{array}$

$\begin{array}{llllllllll}200 & 5 & 0.0568 & 2.9 & 2.7 & -0.1 & 0.0561 & 3.3 & 2.9 & -1.8 \\ 300 & 5 & 0.0579 & 3.4 & 2.9 & -0.2 & 0.0593 & 4.6 & 4.0 & 2.9\end{array}$

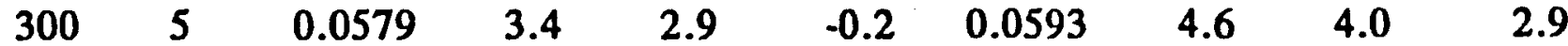


Table 36. Correlation of $A_{i j}$ by Molecular Weight of n-Paraffins

\begin{tabular}{lcccc} 
Solute & $\mathrm{M}_{0}$ & \multicolumn{3}{c}{$\mathrm{A}_{\mathrm{ij}}^{x}$, mole/ $\mathrm{ML}$} \\
\hline & & $100^{\circ} \mathrm{C}$ & $200^{\circ} \mathrm{C}$ & $300^{\circ} \mathrm{C}$ \\
\hline $\mathrm{H}_{2}$ & 127.30 & 0.2632 & 0.2456 & 0.2406 \\
$\mathrm{CO}$ & 140.75 & 0.1842 & 0.1723 & 0.1707 \\
$\mathrm{CH}_{4}$ & 146.06 & 0.1032 & 0.1009 & 0.1050 \\
$\mathrm{C}_{2} \mathrm{H}_{6}$ & 188.16 & 0.05046 & 0.04967 & 0.05277 \\
$\mathrm{CO}_{2}$ & 137.02 & 0.1121 & 0.09710 & 0.09240 \\
$\mathrm{C}_{2} \mathrm{H}_{4}$ & 164.89 & 0.05991 & 0.05884 & 0.06214
\end{tabular}


Table 37. Comparison of Calculated Gas Solubilities of Synthesis Gas Mixtures in n-Octacosane with Experimental Data

\begin{tabular}{|c|c|c|c|c|c|c|}
\hline \multirow[b]{2}{*}{$\mathrm{p}$, atm } & \multicolumn{2}{|c|}{-Experimental- } & \multicolumn{2}{|c|}{-Optimal $A_{i j}$} & \multicolumn{2}{|c|}{-Correlated $A_{i j}$} \\
\hline & $\mathbf{x}_{\mathrm{H}}$ & $\mathbf{x}_{\mathrm{CO}}$ & $\mathbf{x}_{\mathrm{H}}$ & $x_{\mathrm{CO}}$ & $\mathbf{x}_{\mathrm{H}}$ & $\mathbf{x}_{\mathrm{CO}}$ \\
\hline \multicolumn{7}{|c|}{$\begin{array}{c}\text { Equilibrium Gas Composition: } 40.01 \% \mathrm{H}_{2}+59.99 \% \mathrm{CO} \\
200.1^{\circ} \mathrm{C}\end{array}$} \\
\hline 19.74 & 0.0164 & 0.0326 & 0.016 & 0.0339 & 0.0167 & 0.0333 \\
\hline & 0.0 & & & & & 0.0487 \\
\hline & 0.0 & & & & & \\
\hline \multirow[t]{2}{*}{49.89} & 0.04 & & 0.0376 & 0.0766 & 0.0 & 0.0753 \\
\hline & & & $\begin{array}{c}3.4 \\
299.8^{\circ} \mathrm{C}\end{array}$ & & & \\
\hline 19.9 & 0.022 & & 0.0237 & 0.04 & & \\
\hline & 0.03 & & & & & 0.0590 \\
\hline & 0.0 & & & $0.0^{\circ}$ & & 0.0754 \\
\hline \multirow[t]{2}{*}{49.81} & 0.0525 & & 0.05 & 0.0904 & 0.0505 & 0.0897 \\
\hline & & & 2.2 & 4.1 & & 4.9 \\
\hline
\end{tabular}

Equilibrium Gas Composition: $50.01 \% \mathrm{H}_{2}+49.99 \% \mathrm{CO}$ $199.7^{\circ} \mathrm{C}$

$\begin{array}{ccccccc}19.70 & 0.0201 & 0.0275 & 0.0207 & 0.0282 & 0.0208 & 0.0277 \\ 29.94 & 0.0303 & 0.0407 & 0.0303 & 0.0412 & 0.0305 & 0.0405 \\ 39.99 & 0.0415 & 0.0544 & 0.0390 & 0.0531 & 0.0393 & 0.0522 \\ 49.90 & 0.0494 & 0.0653 & 0.0471 & 0.0639 & 0.0474 & 0.0628 \\ & & \text { AAD \% } & 3.4 & 2.0 & 3.3 & 2.2 \\ 19.79 & 0.0281 & 0.0340 & 0.0294 & 0.0344 & 0.0288 & 0.0341 \\ 29.87 & 0.0412 & 0.0506 & 0.0423 & 0.0494 & 0.0414 & 0.0490 \\ 40.17 & 0.0552 & 0.0661 & 0.0543 & 0.0634 & 0.0532 & 0.0629 \\ 49.78 & 0.0656 & 0.0785 & 0.0645 & 0.0754 & 0.0632 & 0.0748 \\ & & \text { AAD \% } & 2.6 & 2.9 & 2.5 & 3.2\end{array}$

Equilibrium Gas Composition: $66.64 \% \mathrm{H}_{2}+33.36 \% \mathrm{CO}$ $200.1^{\circ} \mathrm{C}$
19.94
0.0275
0.0181
0.0279
0.0276
0.0407
0.0192
0.0279
0.0281
0.0187
40.17
0.0543
0.0359
0.0524
0.0359
0.0410
0.0273
49.91
0.0657
0.0434
0.0629
0.0431
0.0527
0.0350
AAD \%
2.9
1.9
0.0634
0.0421
$19.93 \quad 0.0378$
0.0228
$299.9^{\circ} \mathrm{C}$
30.07
0.0562
0.0340
0.0394
0.0232
0.0567
0.0334
0.0724
0.0427
0.0860
0.0507
2.5
2.4
49.80
0.0887
0.0535
2.6
3.3
0.0386
0.0556
0.0229
0.0710
0.0329
AAD \%
0.0843
3.1
0.0421
0.0500
4.0 
Table 38. Comparison of the Modified Soave Equation Calculated Gas Solubilities in Mobil Wax with Experimental Data

\begin{tabular}{|c|c|c|c|c|c|c|}
\hline Gas & $\stackrel{t,}{\circ}$ & Data & $\mathbf{A}_{i j}^{*}$ & Dev & tions ir & p, \% \\
\hline $\mathrm{H}_{2}$ & 200 & $\frac{5}{5}$ & 0.243 & 6.6 & 5.0 & -2.8 \\
\hline & 270 & 4 & 0.239 & 6.2 & 5.2 & 5.2 \\
\hline & 300 & 5 & 0.237 & 7.8 & 5.8 & -4.6 \\
\hline $\mathrm{CO}$ & 200 & 5 & 0.170 & 6.5 & 5.4 & -4.3 \\
\hline & 270 & 4 & 0.167 & 3.1 & 2.7 & 1.5 \\
\hline & 300 & 5 & 0.166 & 7.8 & 6.2 & -6.0 \\
\hline $\mathrm{CH}_{4}$ & 200 & 5 & 0.0981 & 6.0 & 4.9 & -1.1 \\
\hline & 270 & 3 & 0.101 & 3.1 & 2.8 & -0.1 \\
\hline & 300 & 5 & 0.102 & 8.6 & 6.7 & -6.0 \\
\hline $\mathrm{CO}_{2}$ & 200 & 5 & 0.0960 & 7.5 & 6.1 & -1.5 \\
\hline & 270 & 3 & 0.0924 & 4.8 & 4.1 & 1.7 \\
\hline & 300 & 5 & 0.0908 & 6.4 & 4.7 & -1.6 \\
\hline $\mathrm{C}_{2} \mathrm{H}_{6}$ & 200 & 4 & 0.0468 & 7.7 & 5.3 & -4.3 \\
\hline & 270 & 3 & 0.0478 & 4.9 & 4.5 & 2.1 \\
\hline & 300 & 4 & 0.0483 & 13.2 & 10.8 & -10.8 \\
\hline
\end{tabular}

* $A_{i j}$ values are taken from those of $n-C_{36}$. 
Table 39. Comparison of the Modified Soave Equation Calculated Gas Solubilities in SASOL Wax with Experimental Data

\begin{tabular}{lcccccc}
\multirow{2}{*}{ Gas } & t, & Data & $\mathrm{A}_{\mathrm{ij}}^{*}$ & \multicolumn{3}{c}{ Deviations in p, \% } \\
& ${ }^{\circ} \mathrm{C}$ & pts & mole/mL & RMS & AAD & BIAS \\
\hline $\mathrm{H}_{2}$ & 200 & 5 & 0.243 & 6.5 & 5.0 & -3.1 \\
& 260 & 5 & 0.239 & 5.4 & 4.7 & 3.9 \\
& 300 & 5 & 0.237 & 5.1 & 4.8 & 1.6 \\
$\mathrm{CO}$ & 200 & 5 & 0.170 & 5.6 & 5.5 & 5.5 \\
& 260 & 5 & 0.168 & 6.4 & 5.8 & 5.8 \\
& 300 & 5 & 0.166 & 3.9 & 3.2 & 3.2 \\
& & & & & & \\
$\mathrm{CH}_{4}$ & 200 & 5 & 0.0981 & 4.4 & 4.0 & -4.0 \\
& 260 & 5 & 0.100 & 3.3 & 2.5 & -2.1 \\
& 300 & 5 & 0.102 & 2.1 & 1.9 & -0.6 \\
& & & & & & \\
$\mathrm{CO}_{2}$ & 260 & 4 & 0.0929 & 2.7 & 2.1 & -1.1 \\
& 300 & 4 & 0.0908 & 1.8 & 1.7 & 0.4 \\
& & & & & & \\
$\mathrm{C}_{2} \mathrm{H}_{6}$ & 200 & 4 & 0.0468 & 3.6 & 2.9 & -2.9 \\
& 260 & 4 & 0.0477 & 2.8 & 2.5 & -1.3 \\
& 300 & 4 & 0.0483 & 7.2 & 6.6 & -6.6 \\
& & & & & & \\
$\mathrm{C}_{2} \mathrm{H}_{4}$ & 200 & 5 & 0.0568 & 2.8 & 2.2 & -1.2 \\
& 260 & 5 & 0.0575 & 4.6 & 3.9 & -3.9
\end{tabular}

* $A_{i j}$ values are taken from those of $n-C_{36}$. 


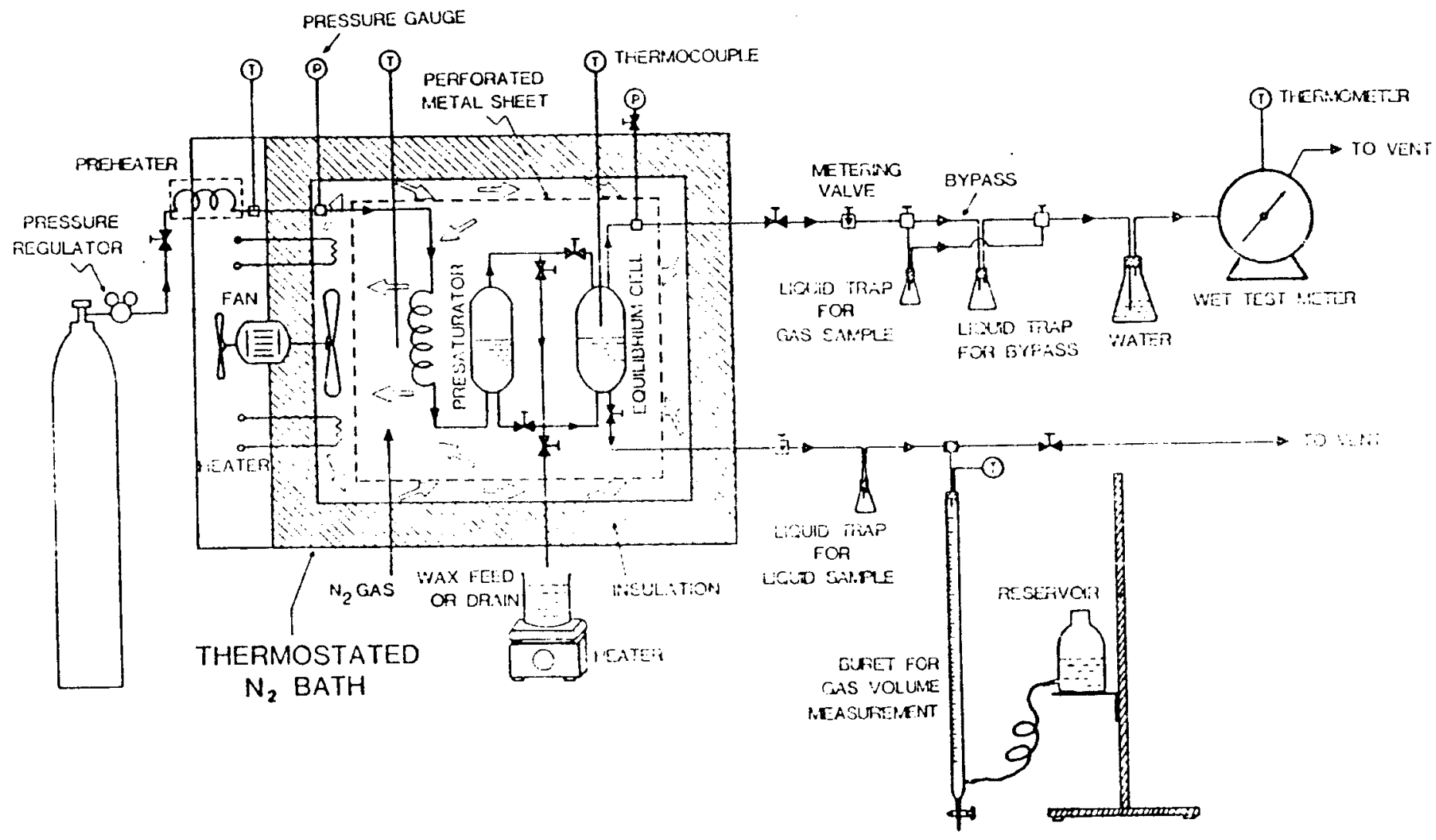

Figure 1. Vapor-Liquid Equilibrium Apparatus 


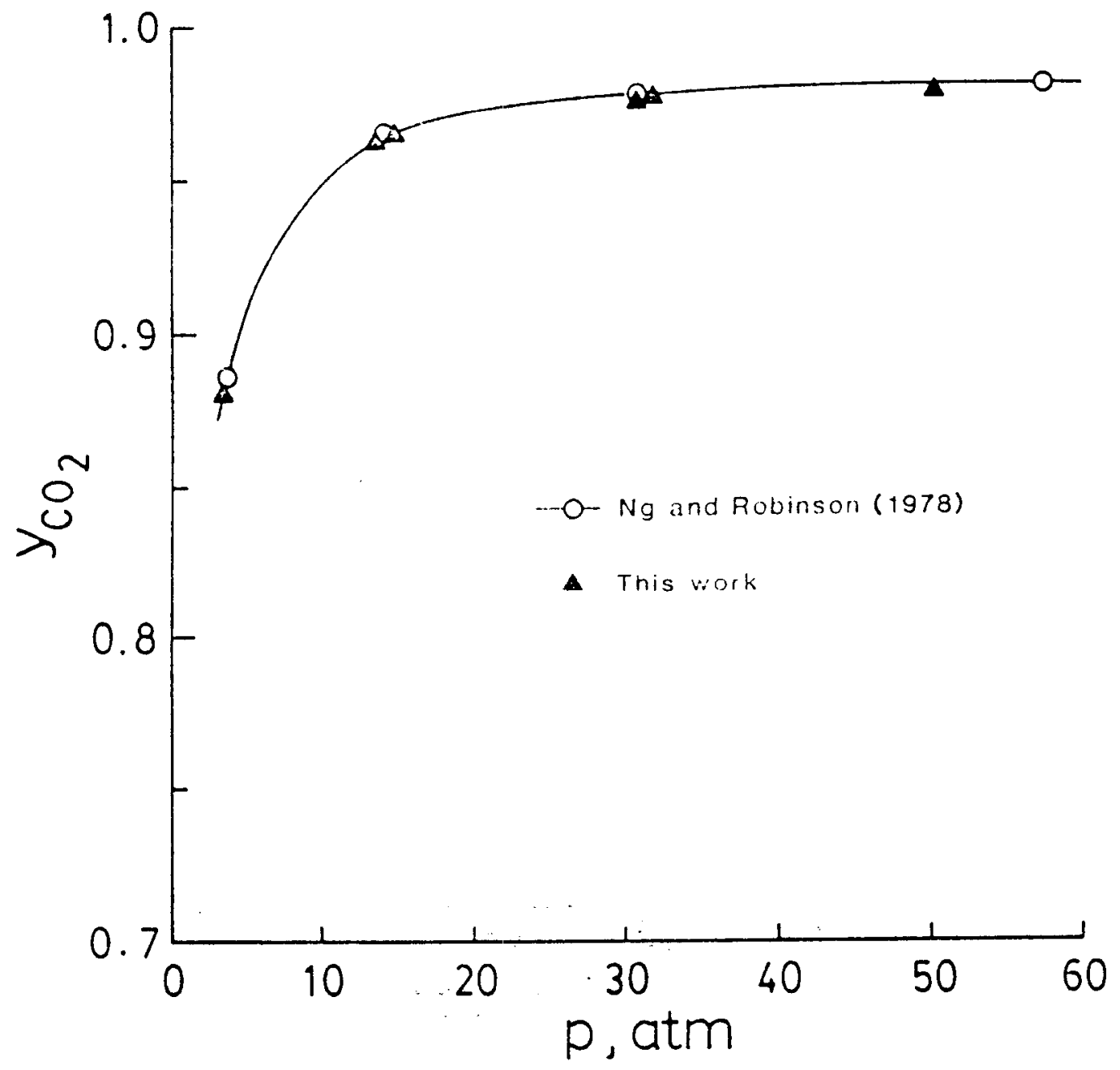

Figure 2. Mole Fraction of $\mathrm{CO}_{2}$ in Saturated Vapor in $\mathrm{CO}_{2}+$ Toluene Mixtures at $80^{\circ} \mathrm{C}$ 


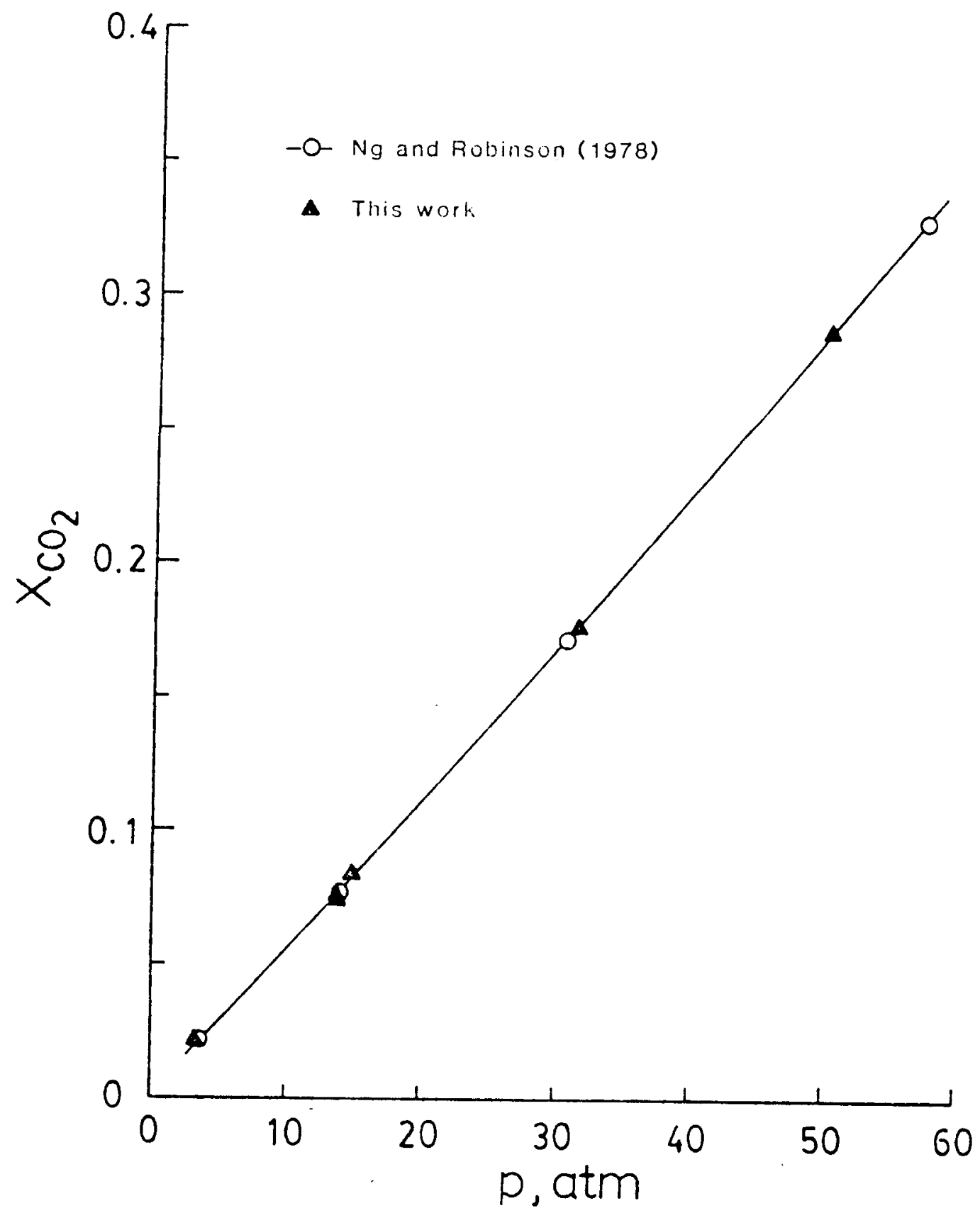

Figure 3. Solubility of $\mathrm{CO}_{3}$ in Toluene at $80^{\circ} \mathrm{C}$ 


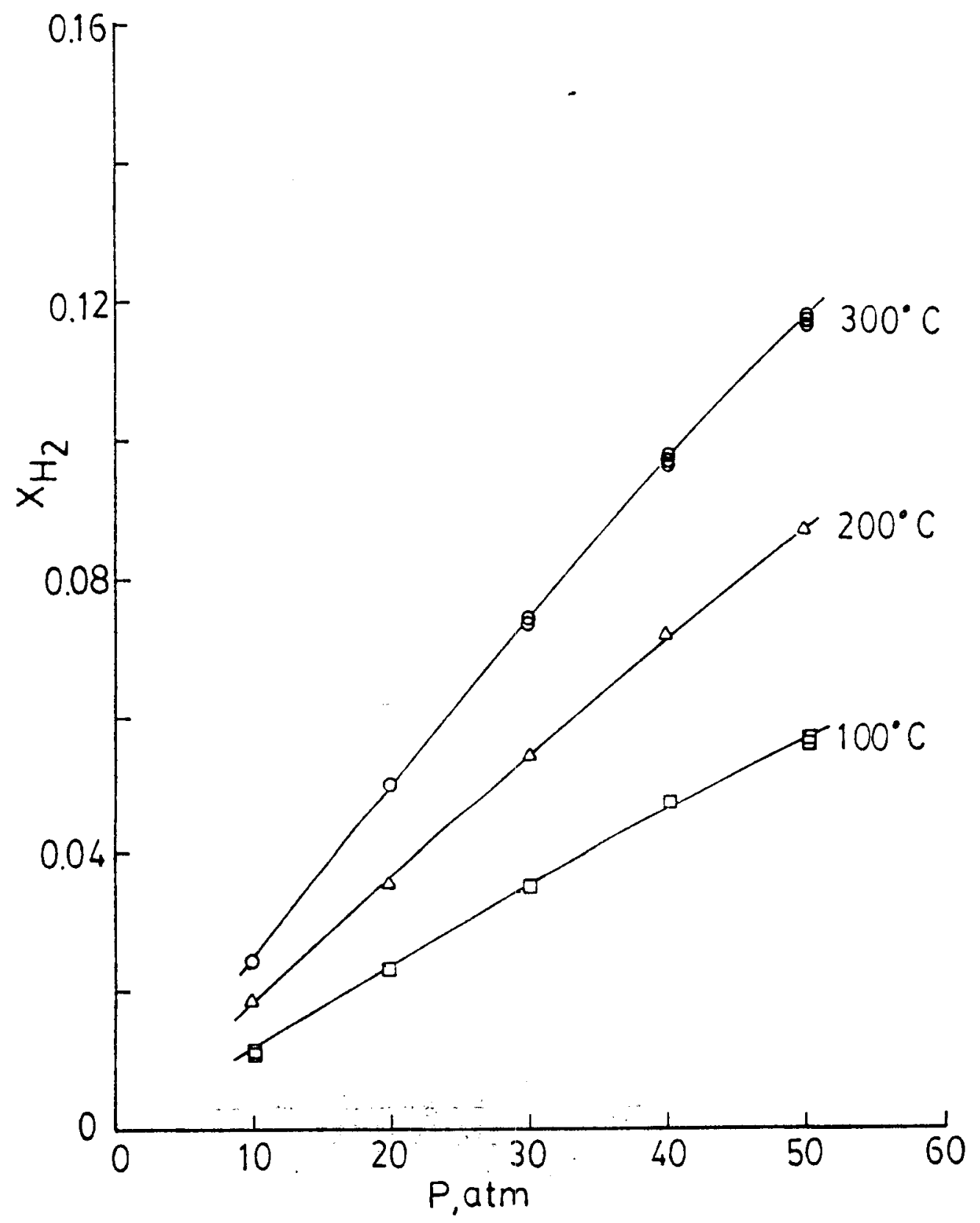

Figure 4. Solubility of Hydrogen in n-Eicosane 


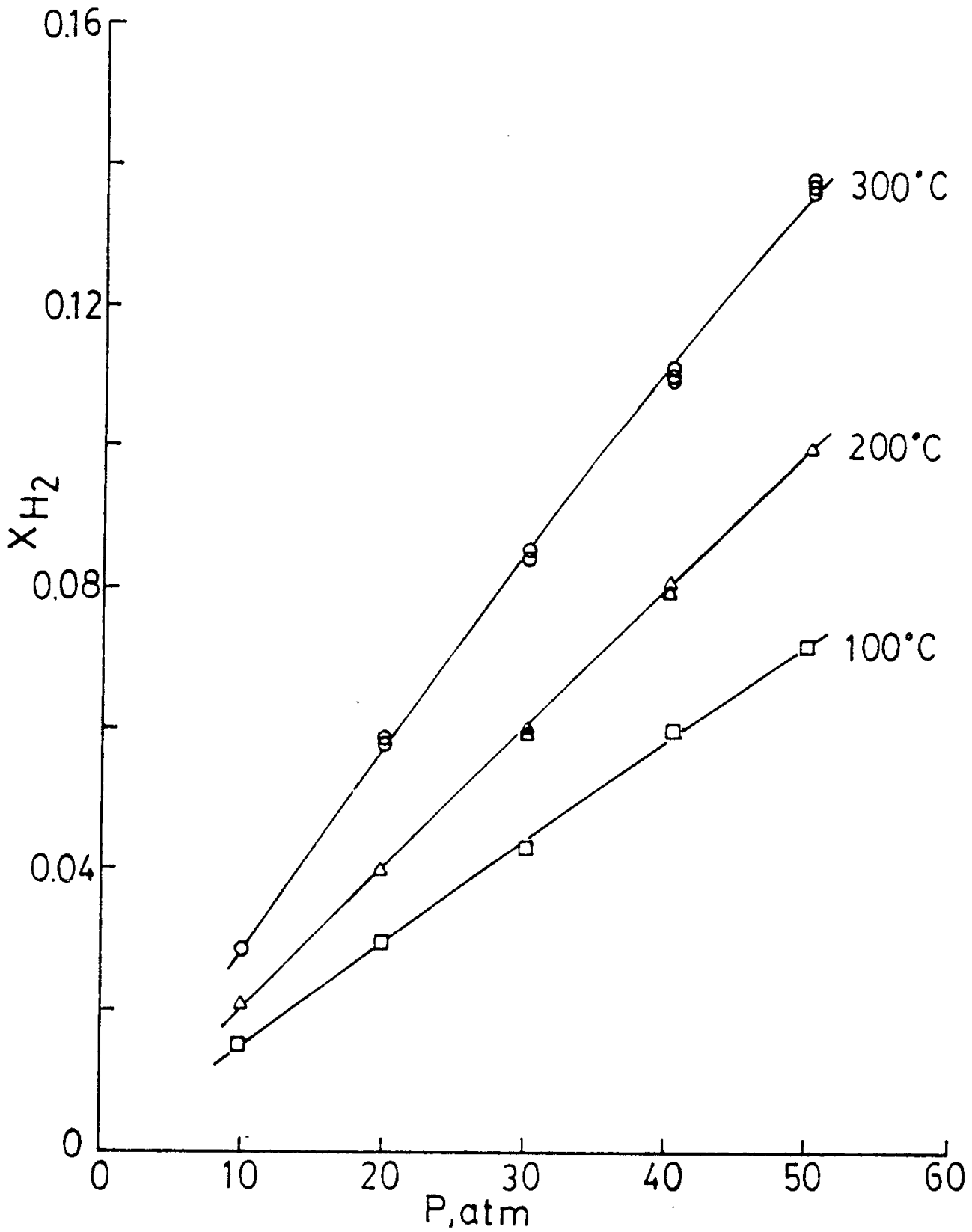

Figure 5. Solubility of Hydrogen in n-Octacosane 


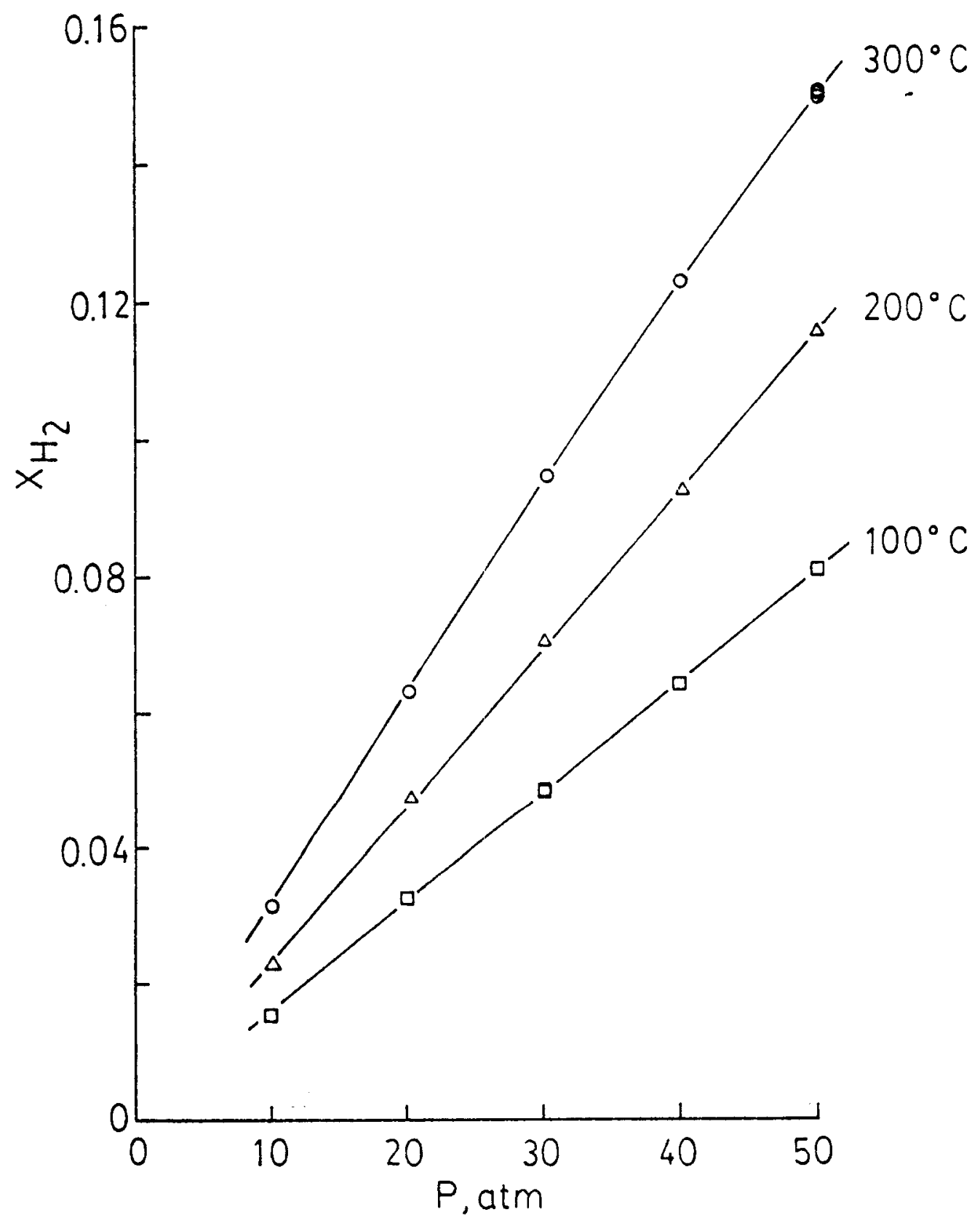

Figure 6. Solubility of Hydrogen in n-Hexatriacontane 


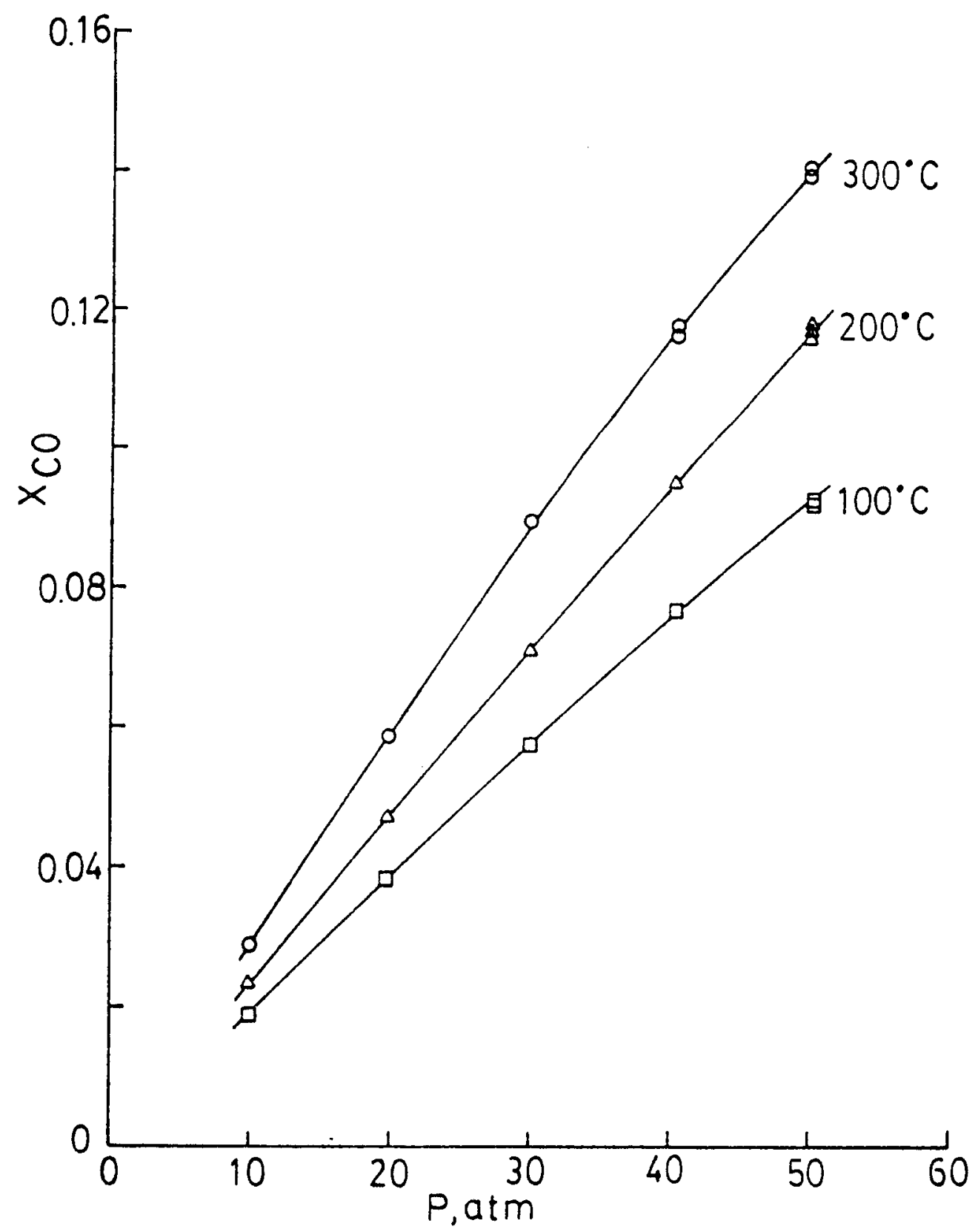

Figure 7. Solubility of Carbon Monoxide in n-Eicosane 


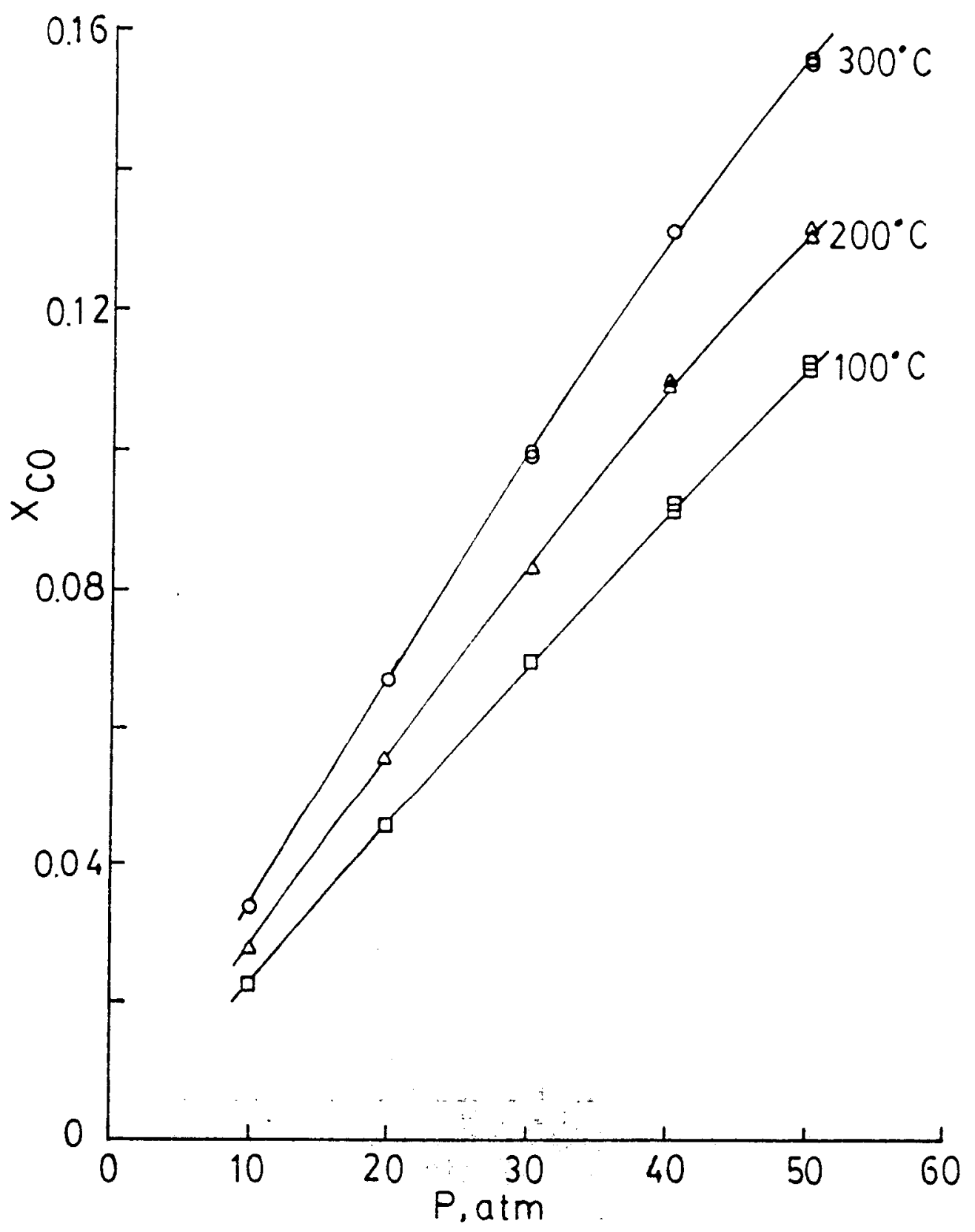

Figure 8. Solubility of Carbon Monoxide in n-Octacosane 


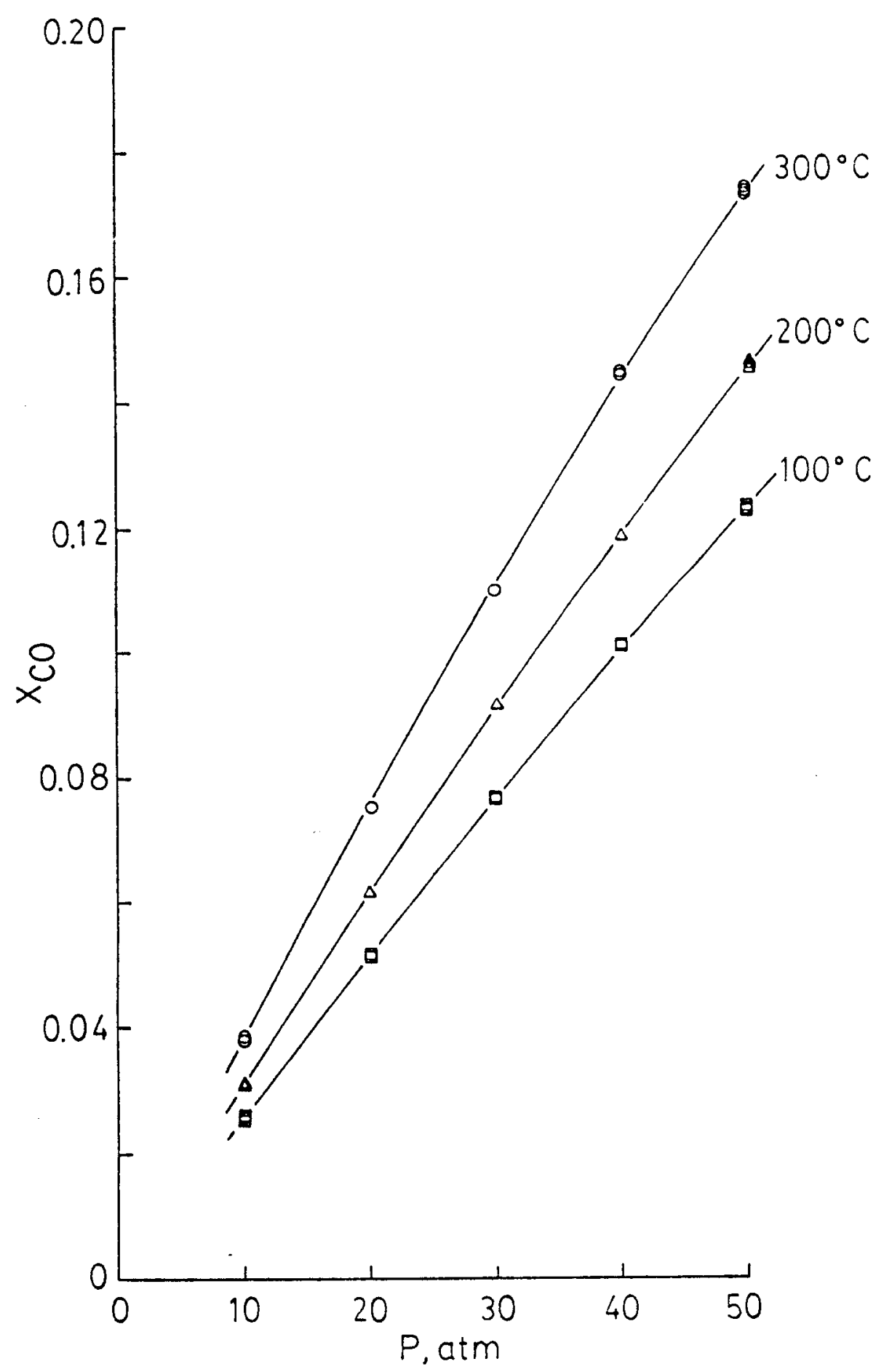

Figure 9. Solubility of Carbon Monoxide in n-Hexatriacontane 


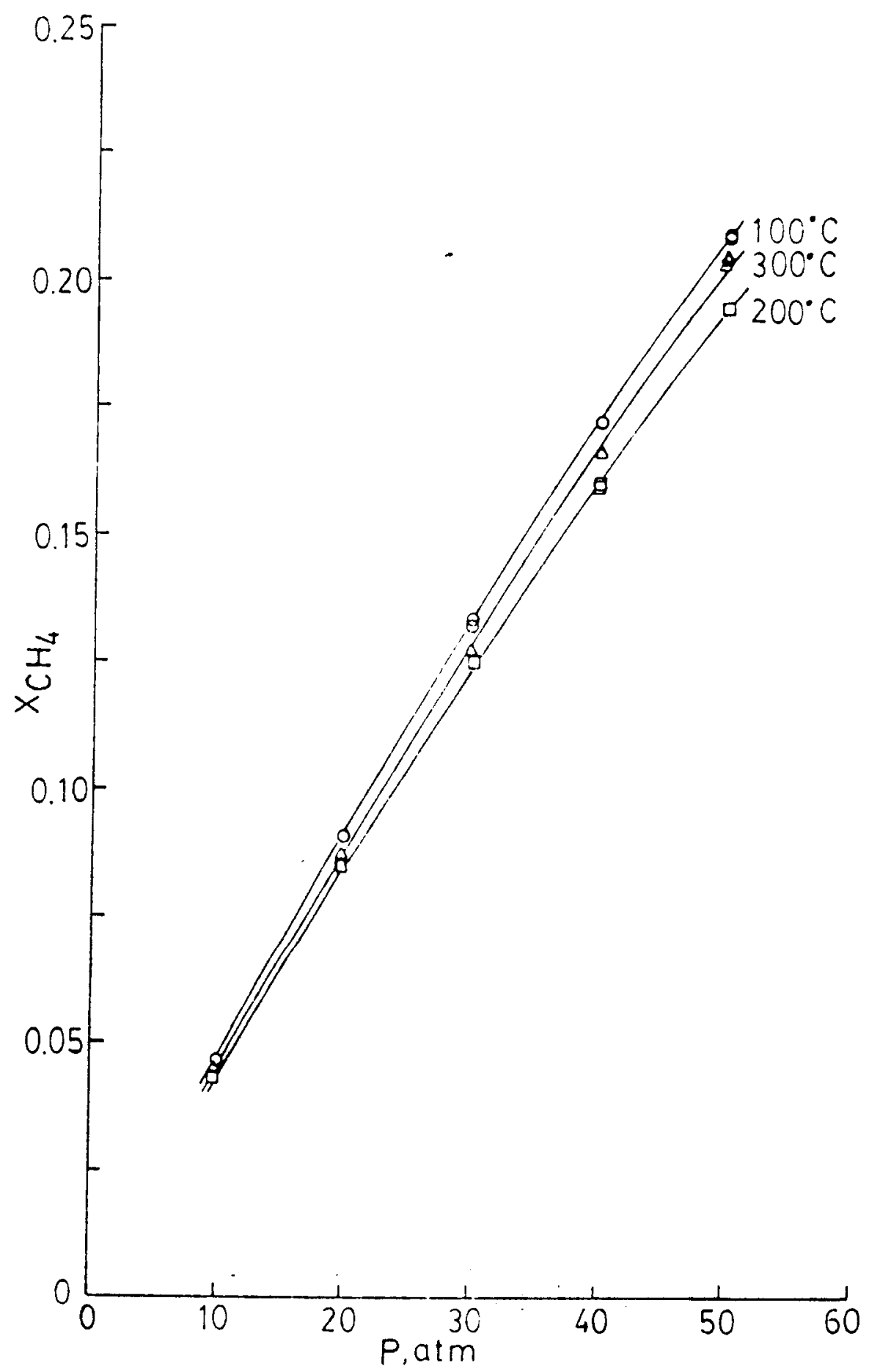

Figure 10. Solubility of Methane in n-Eicosane 


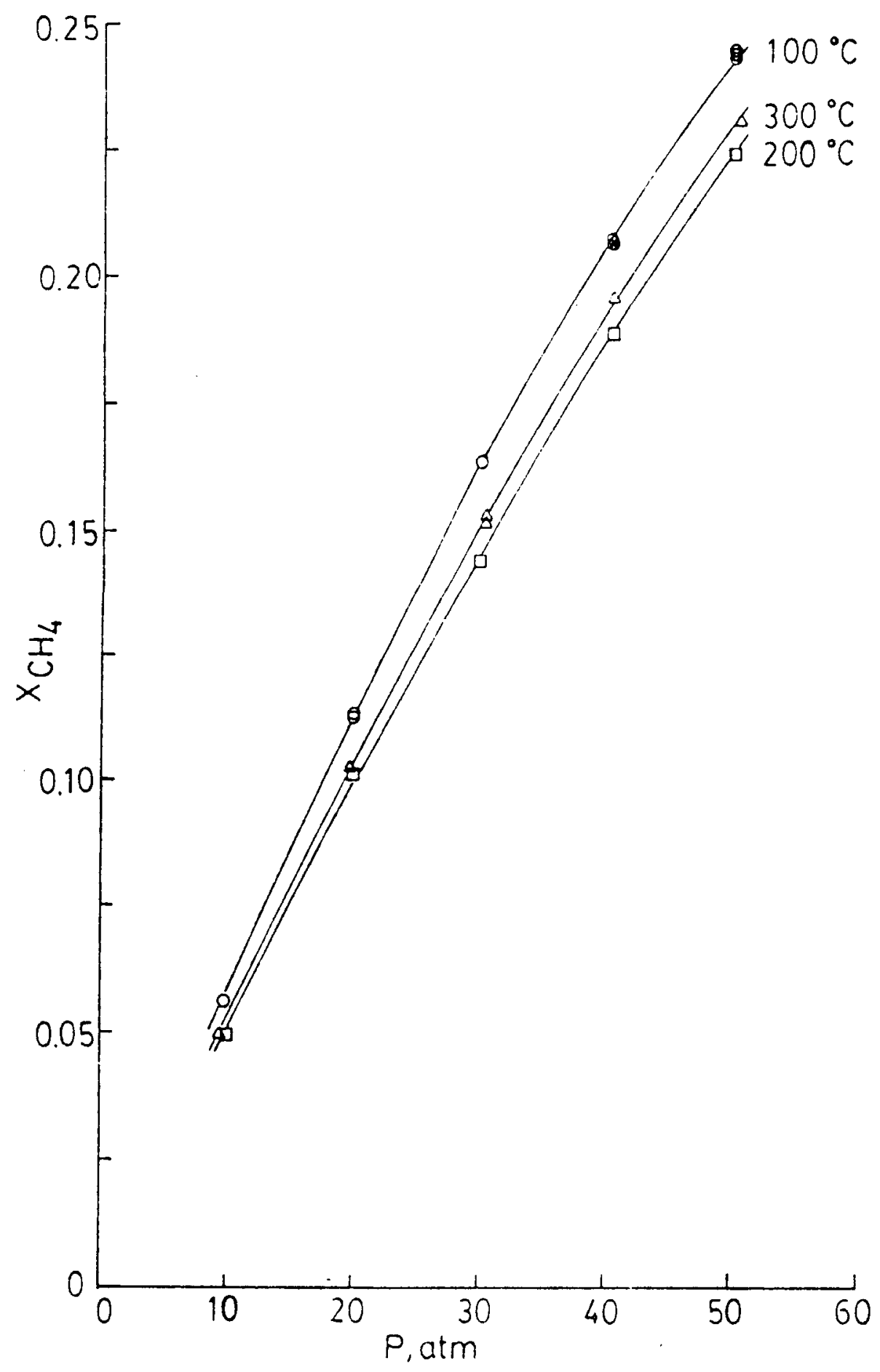

Figure 11. Solubility of Methane in n-Octacosane 


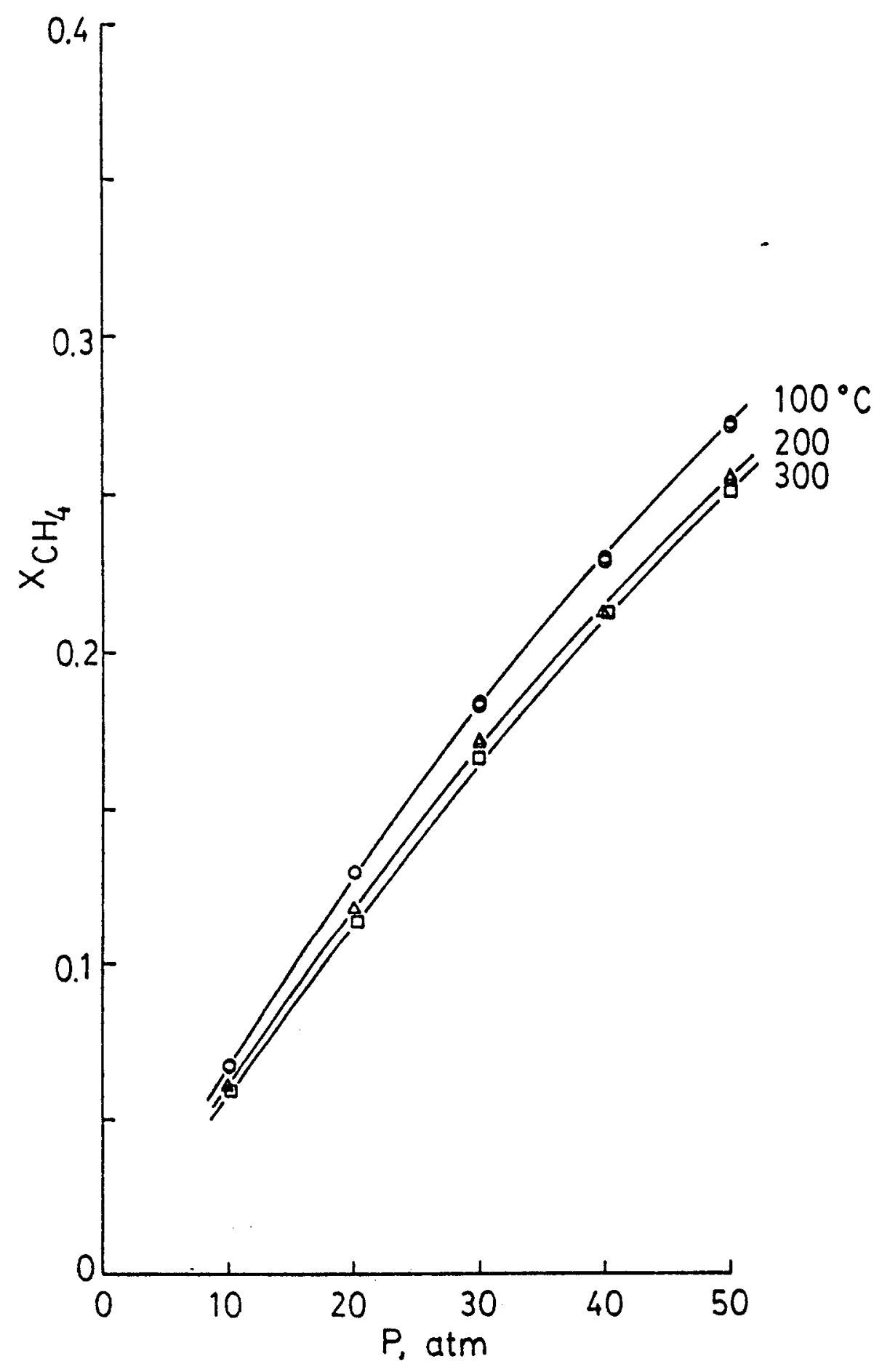

Figure 12. Solubility of Methane in n-Hexatriacontane 


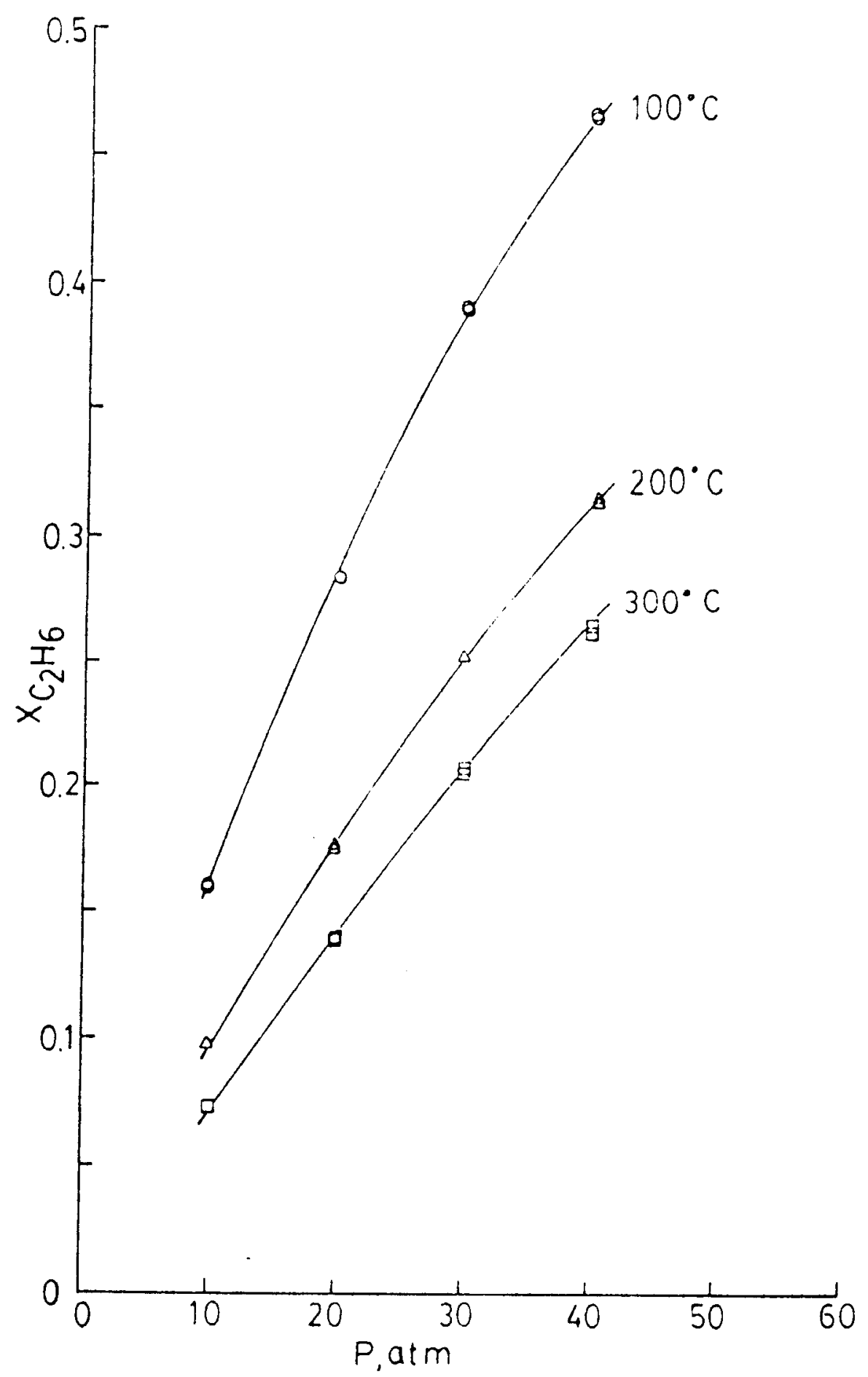

Figure 13. Solubility of Ethane in n-Eicosane 


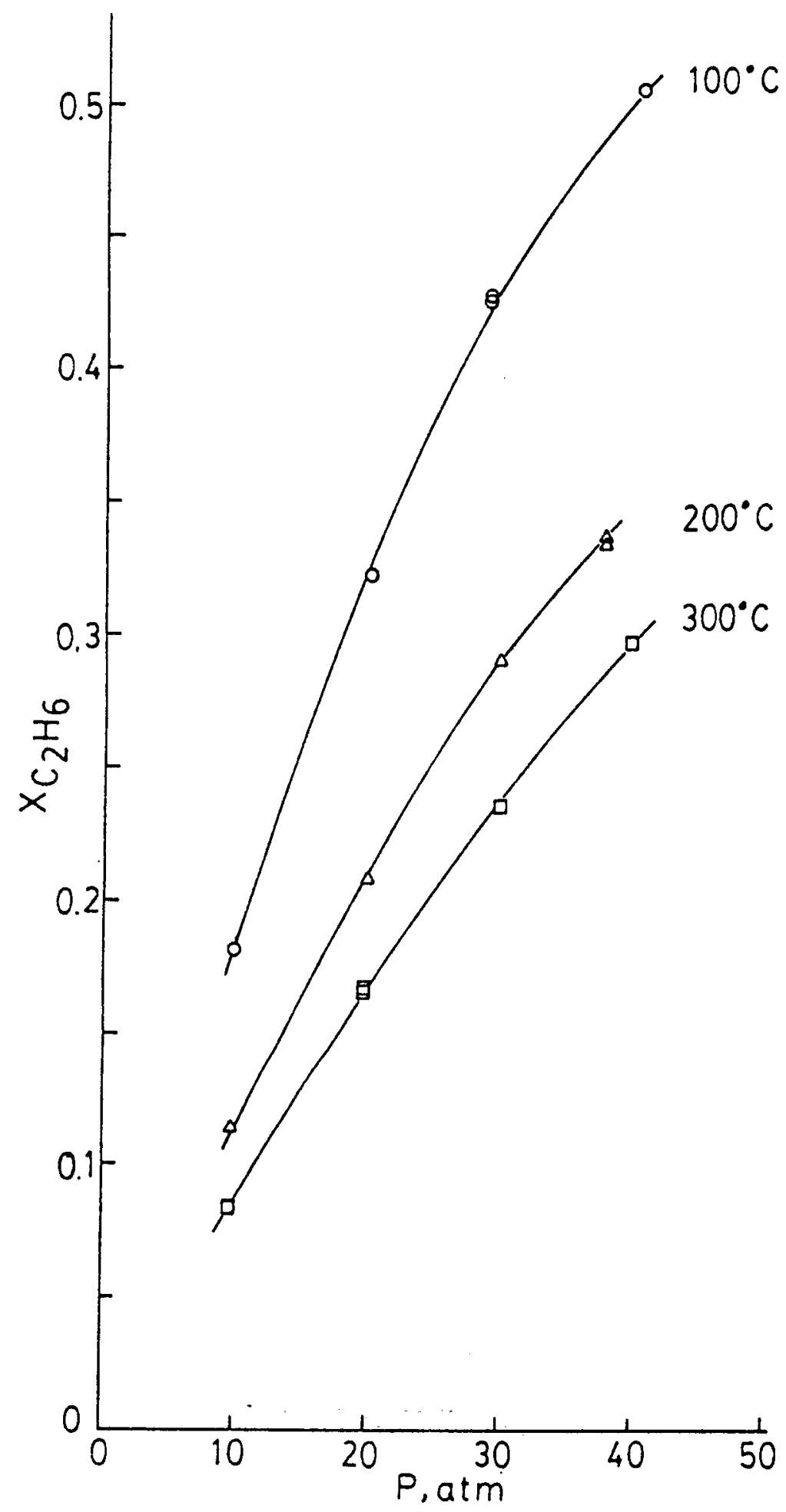

Figure 14. Solubility of Ethane in n-Octacosane 


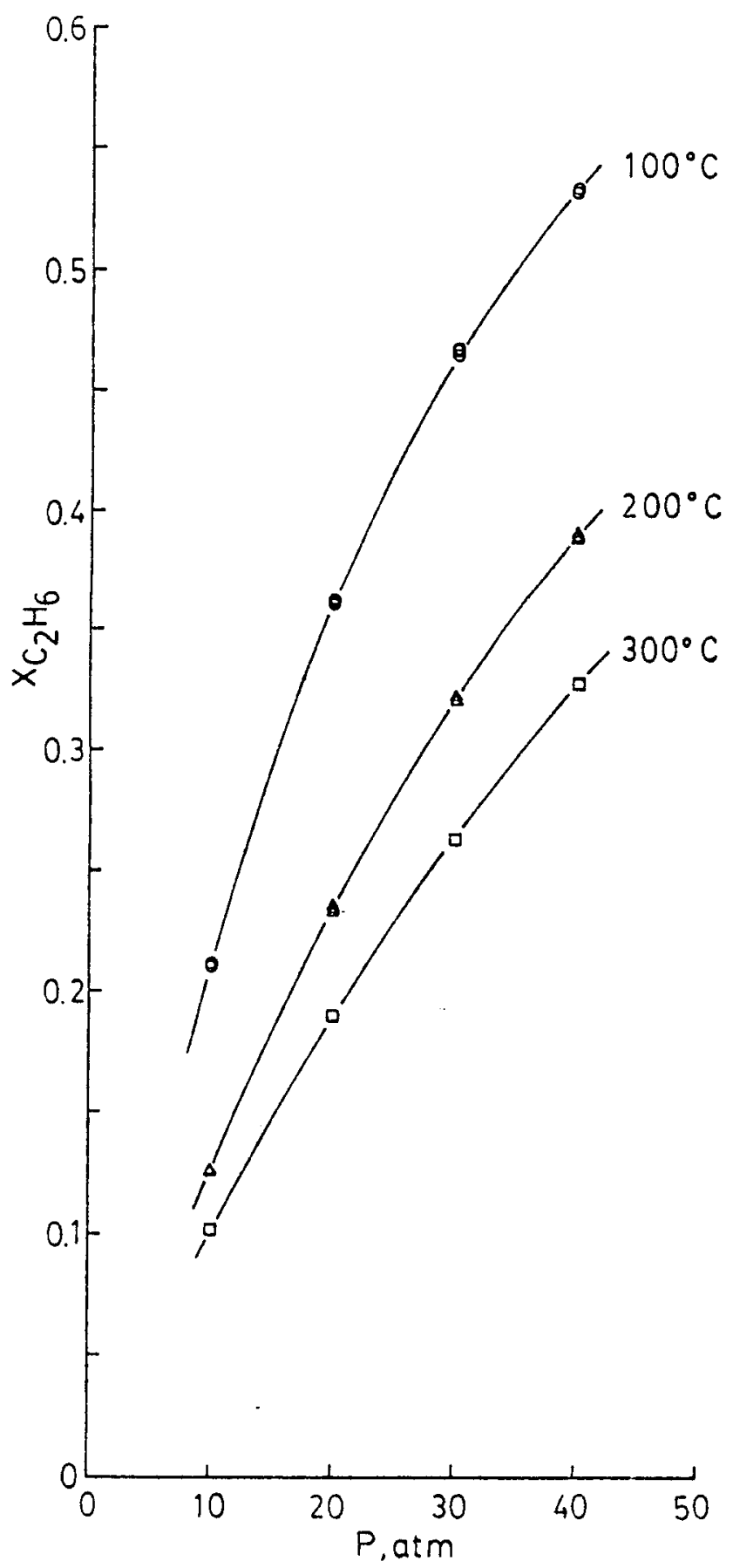

Figure 15. Solubility of Ethane in n-Hexatriacontane 


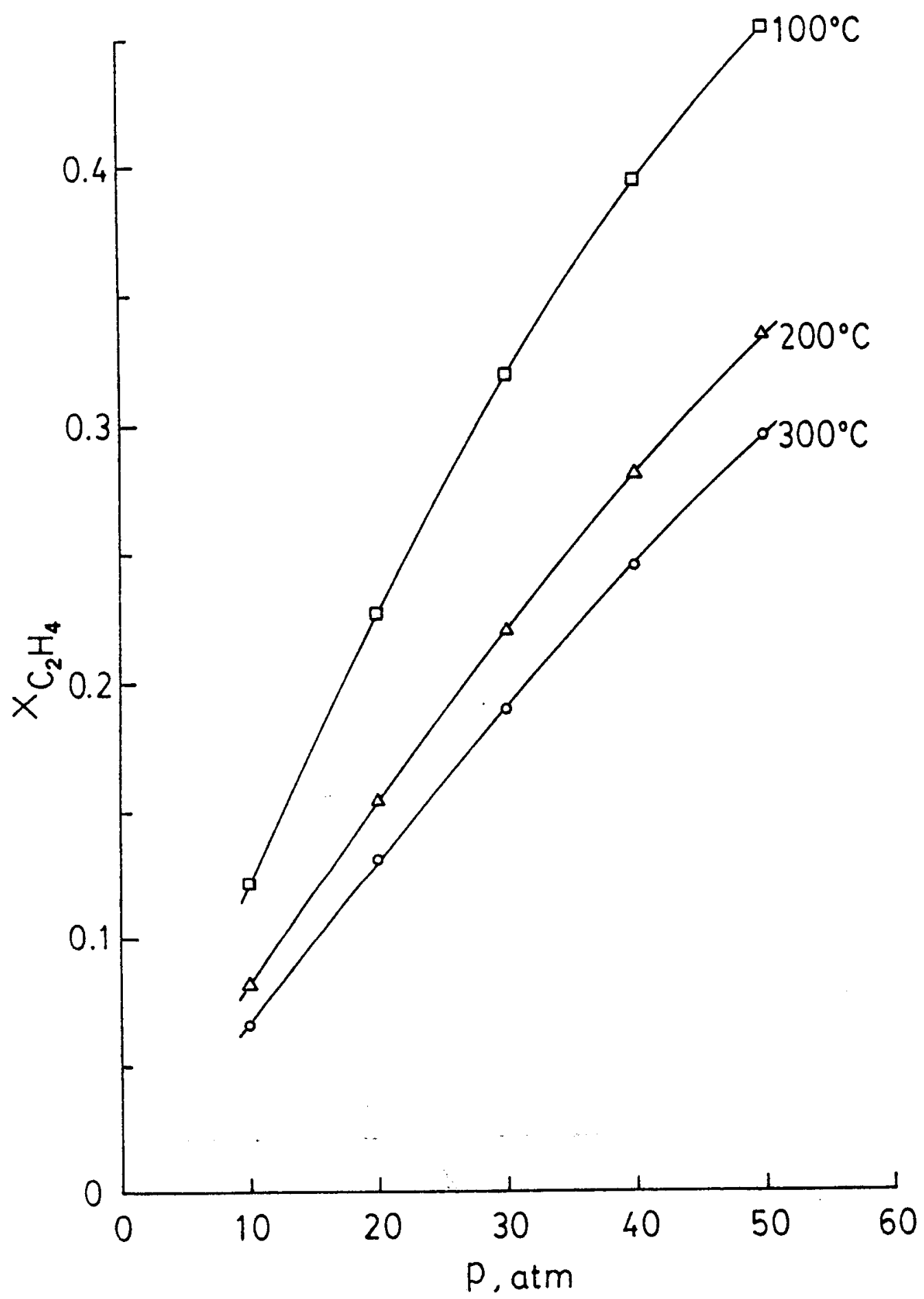

Figure 16. Solubility of Ethylene in n-Eicosane 


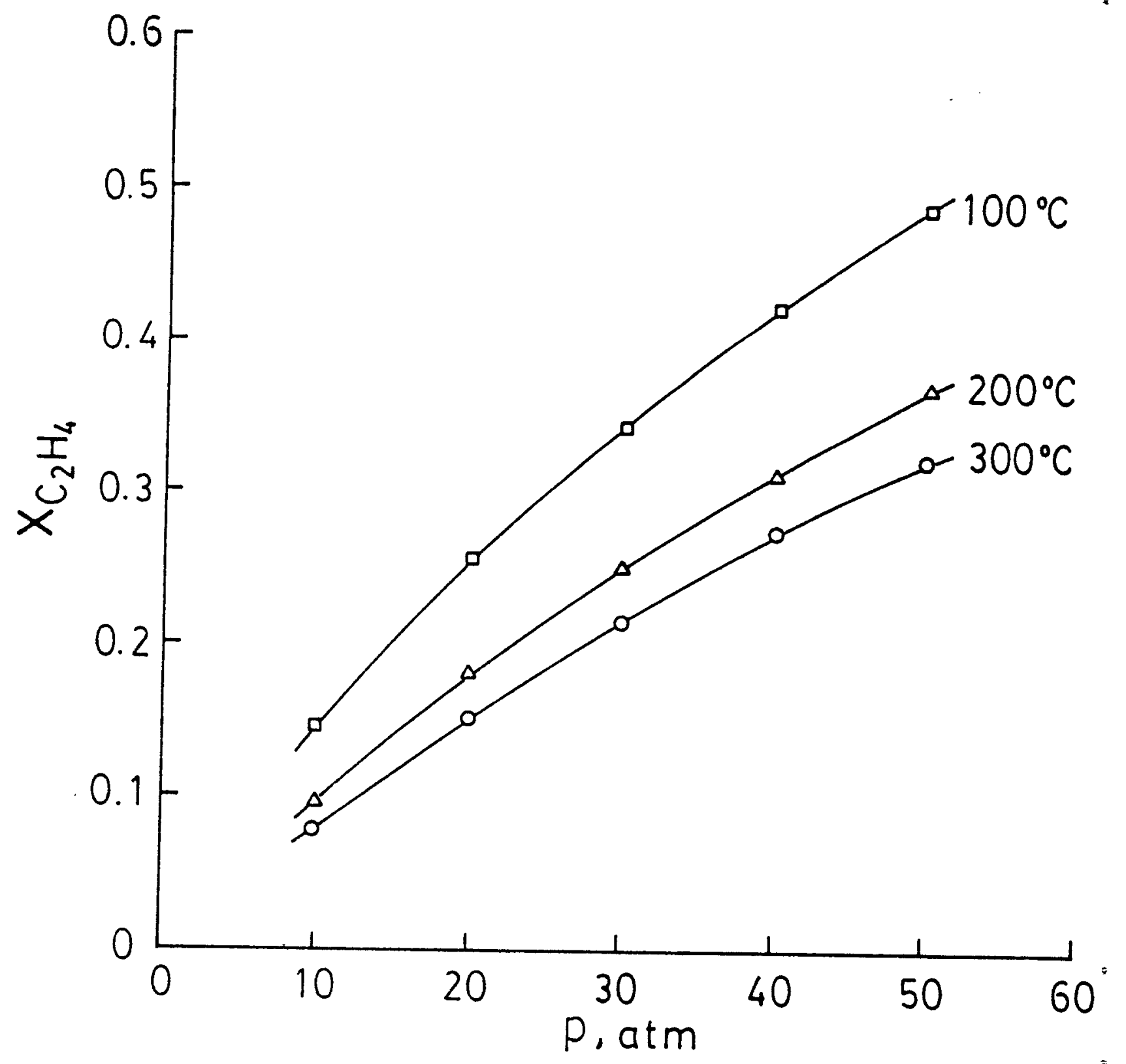

Figure 17. Solubility of Ethylene in n-Octacosane 


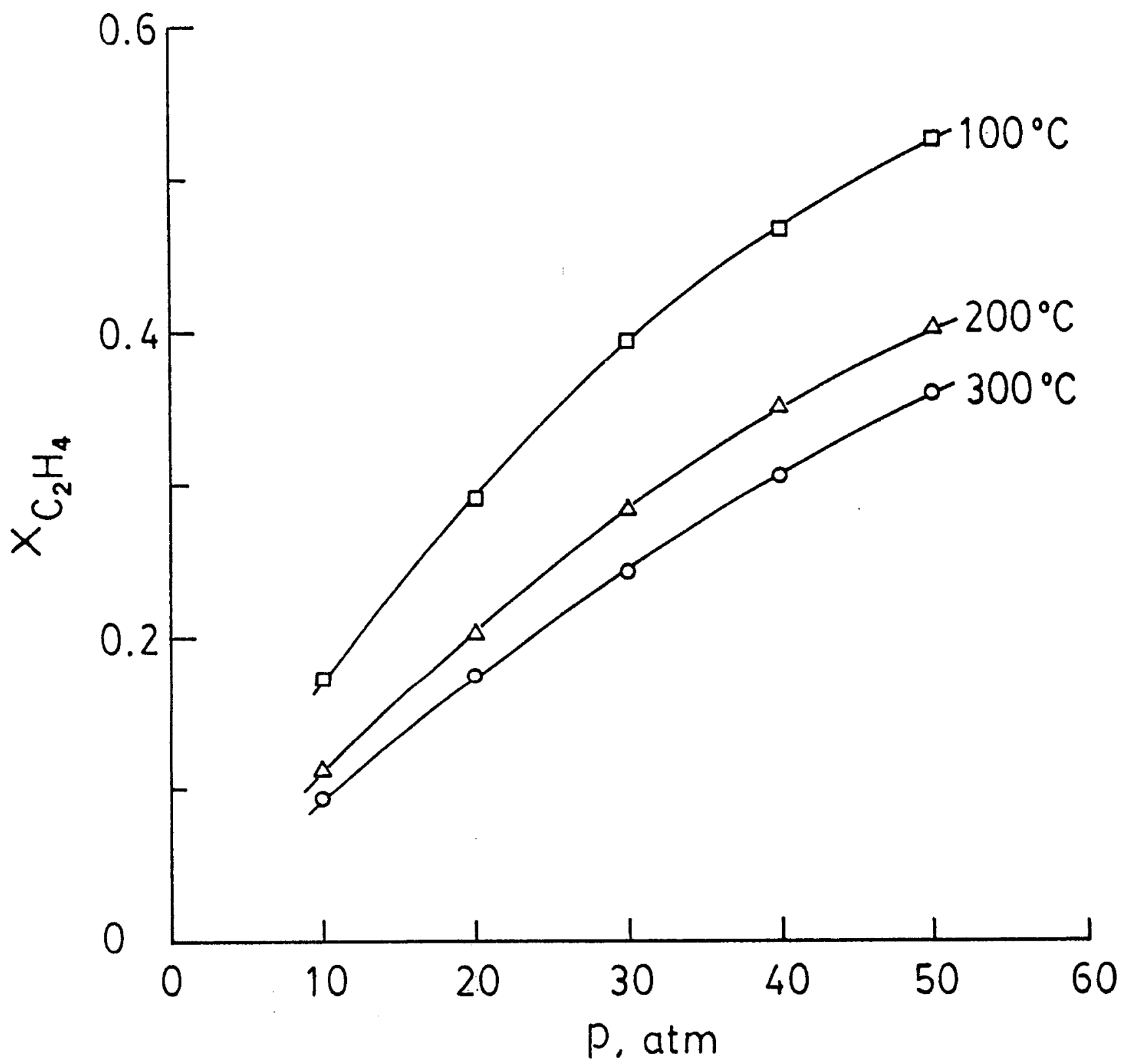

Figure 18. Solubility of Ethylene in n-Hexatriacontane 


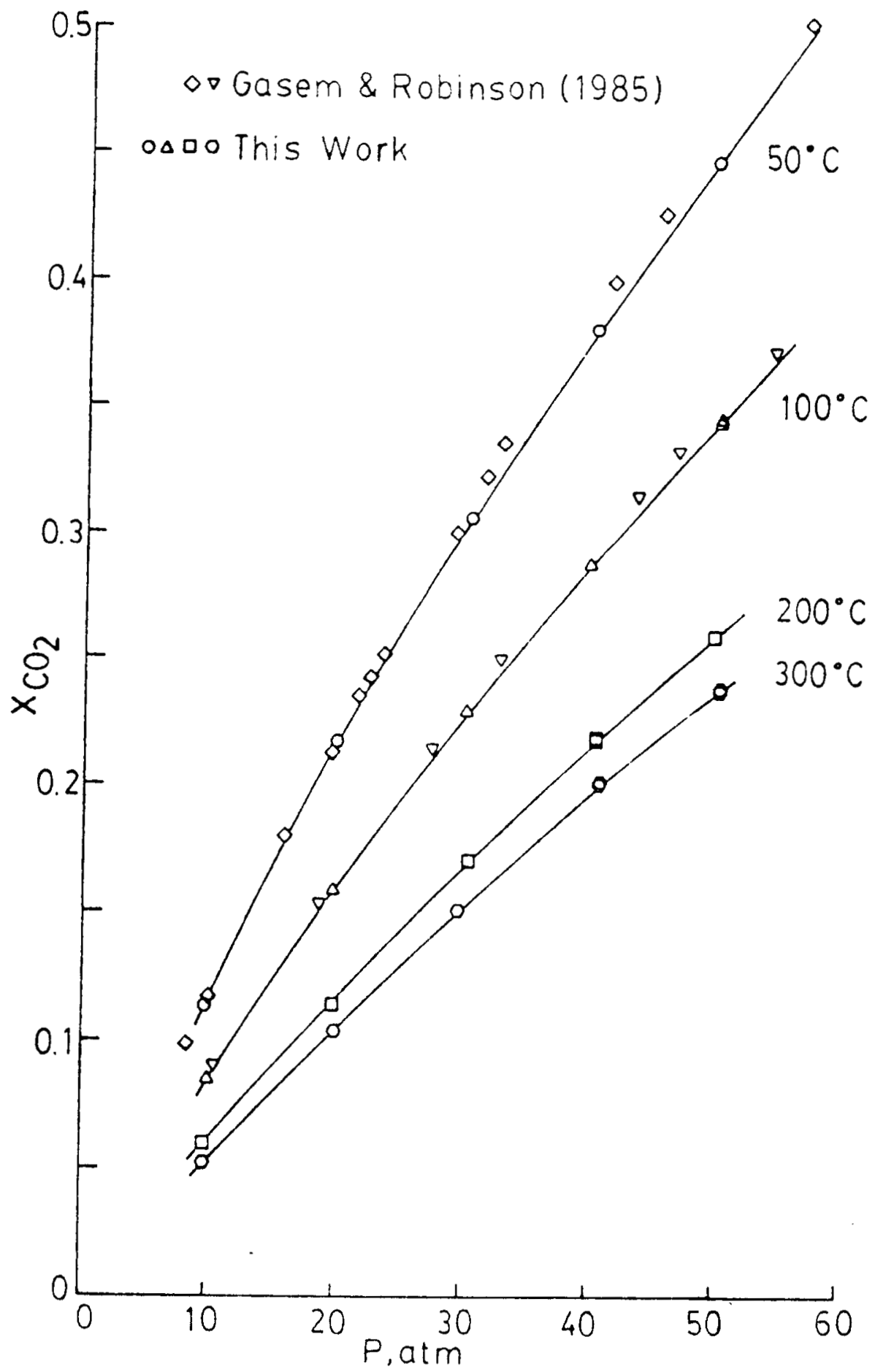

Figure 19. Solubility of Carbon Dioxide in n-Eicosane 


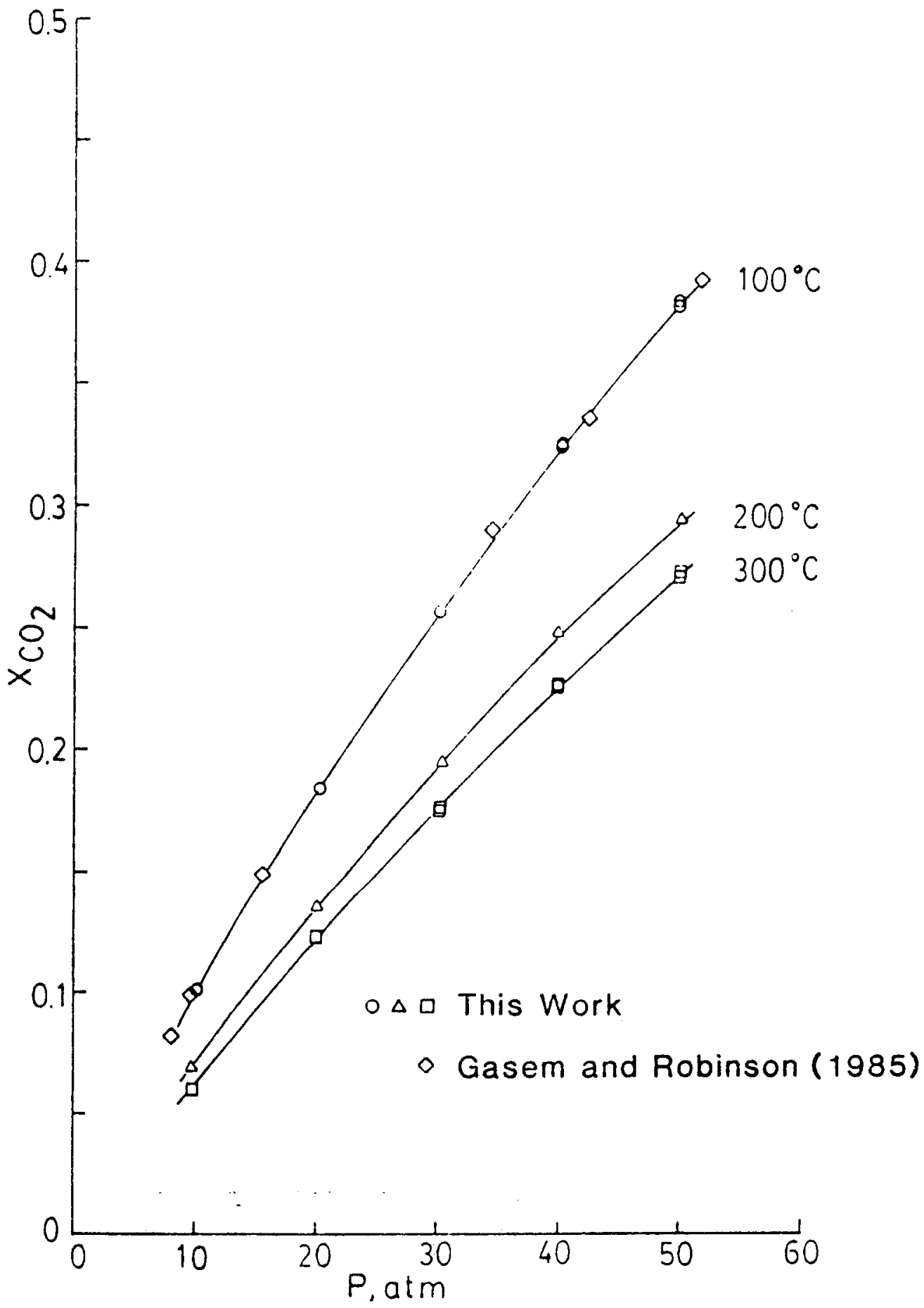

Figure 20. Solubility of Carbon Dioxide in n-Octacosane 


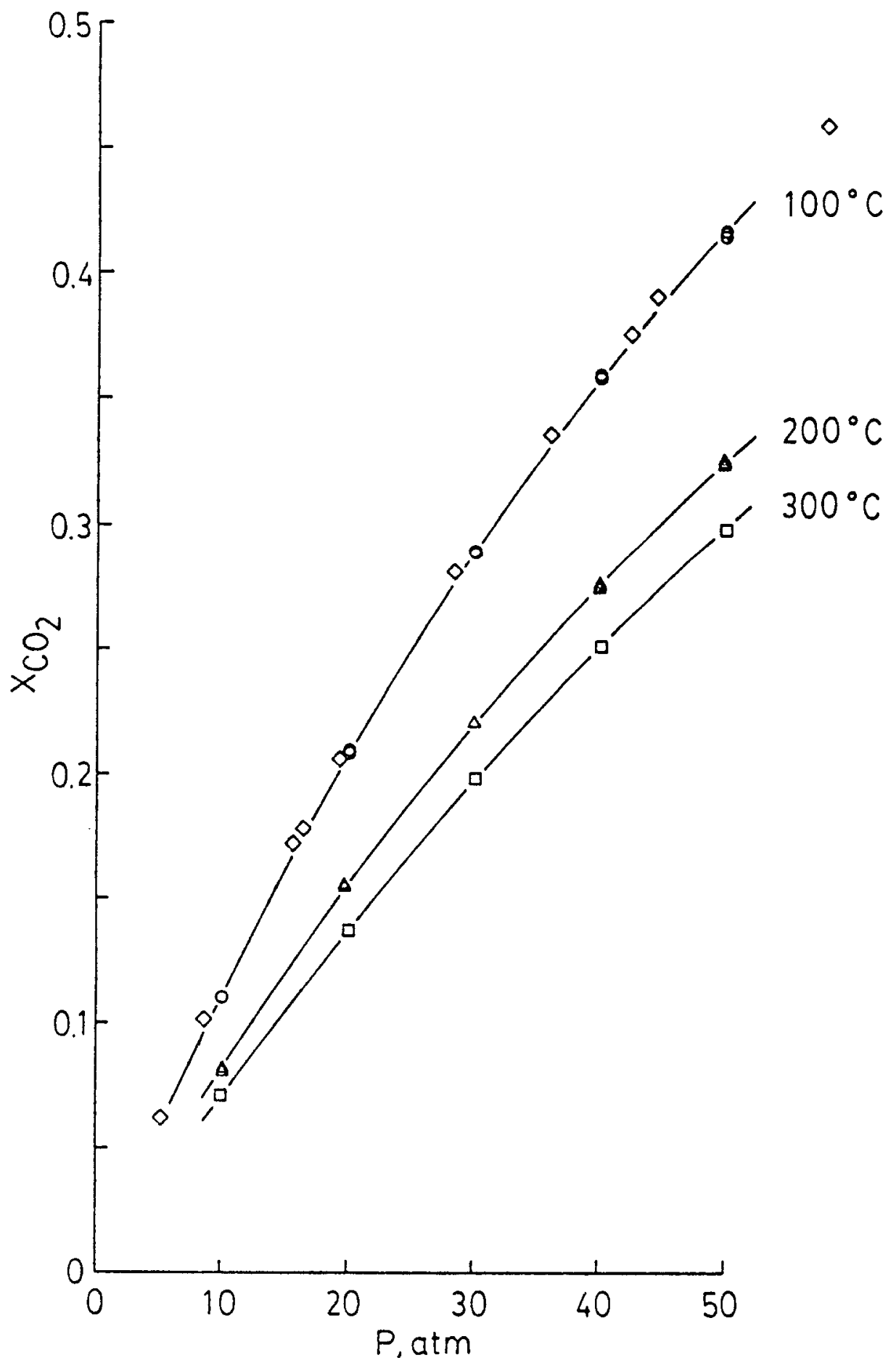

Figure 21. Solubility of Carbon Dioxide in n-Hexatriacontane 


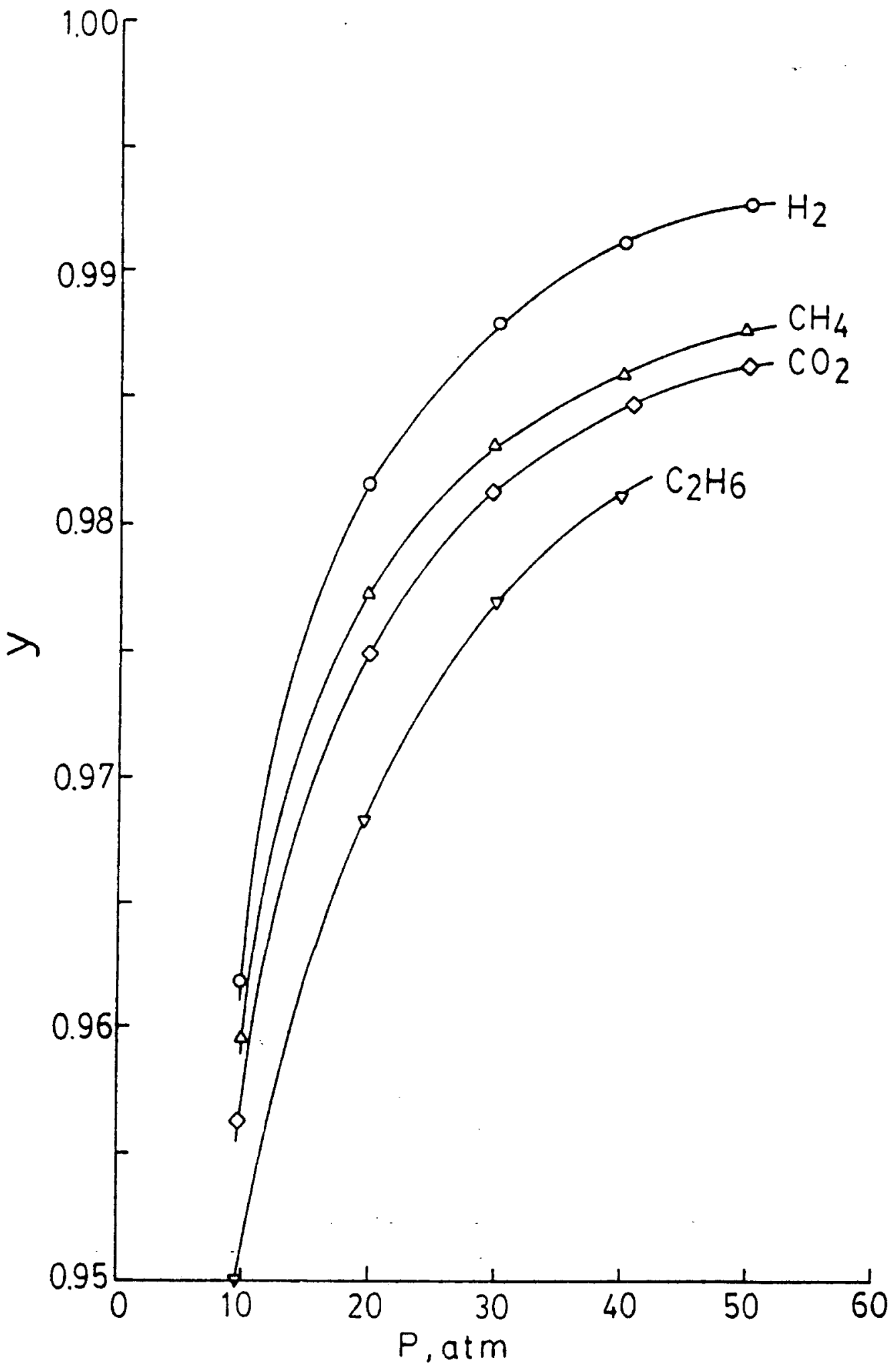

Figure 22. Equilibrium Vapor Composition of Gas in Mixtures with n-Eicosane at $300^{\circ} \mathrm{C}$ 


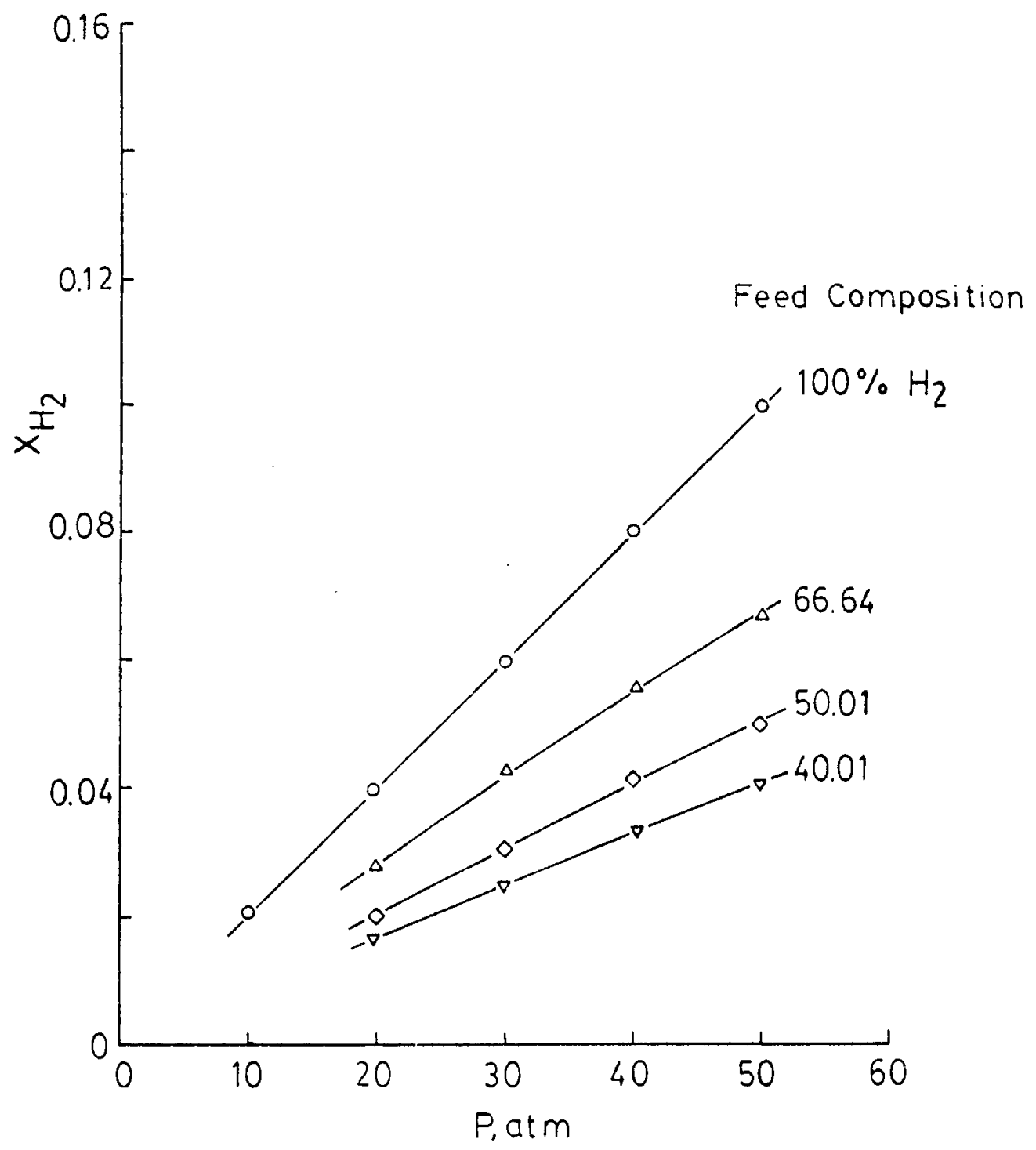

Figure 23. Solubility of $\mathrm{H}_{2}$ in Synthesis Gas Mixtures of $\mathrm{H}_{2}+\mathrm{CO}$ in nOctacosane at $200^{\circ} \mathrm{C}$ 


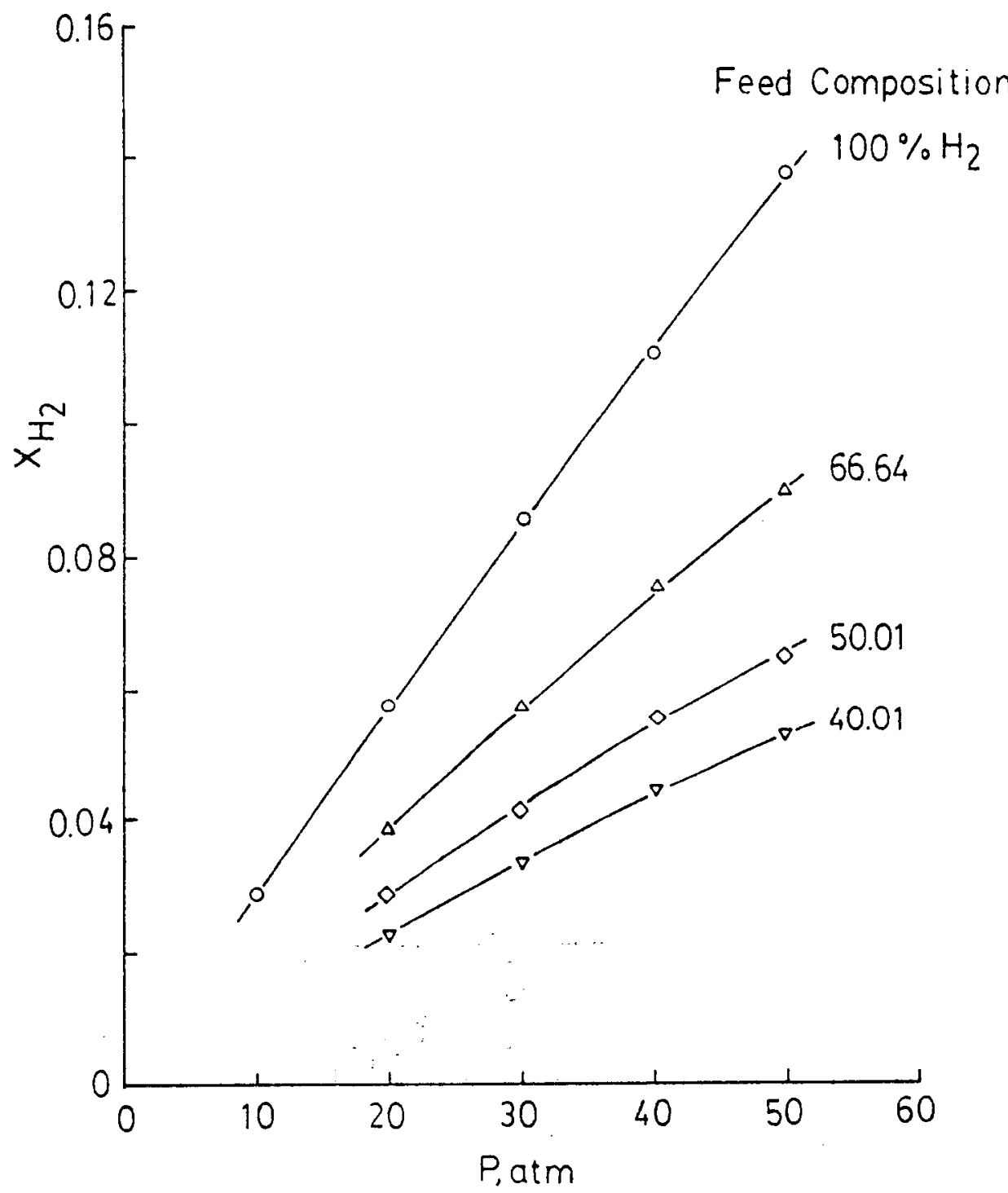

Figure 24. Solubility of $\mathrm{H}_{2}$ in Synthesis Gas Mixtures of $\mathrm{H}_{2}+\mathrm{CO}$ in $\mathbf{n -}$ Octacosane at $300^{\circ} \mathrm{C}$ 


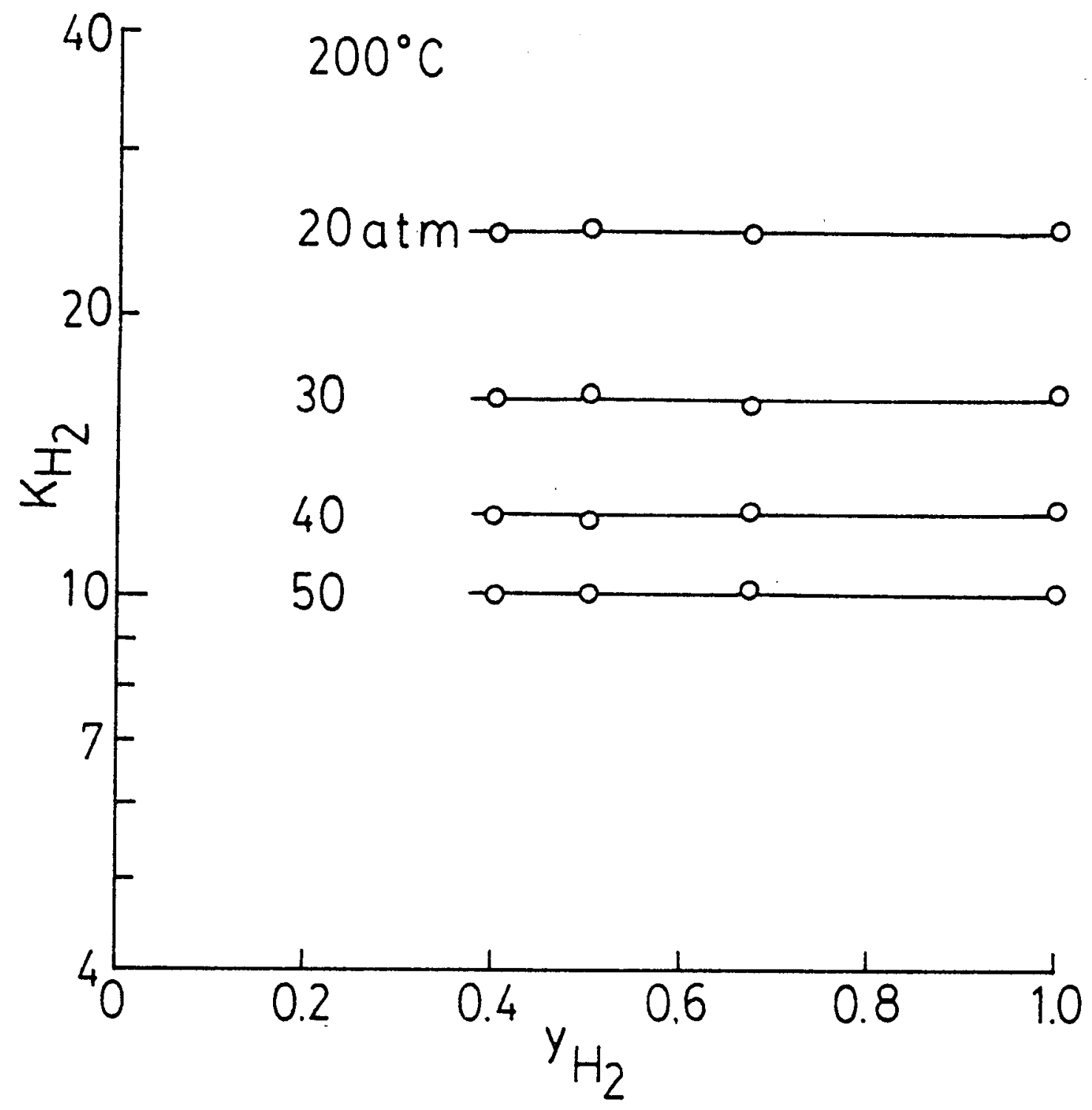

Figure 25. $\mathrm{K}$-values of $\mathrm{H}_{2}$ in $\mathrm{H}_{2}+\mathrm{CO}$ Mixtures in n-Octacosane at $200^{\circ} \mathrm{C}$ 


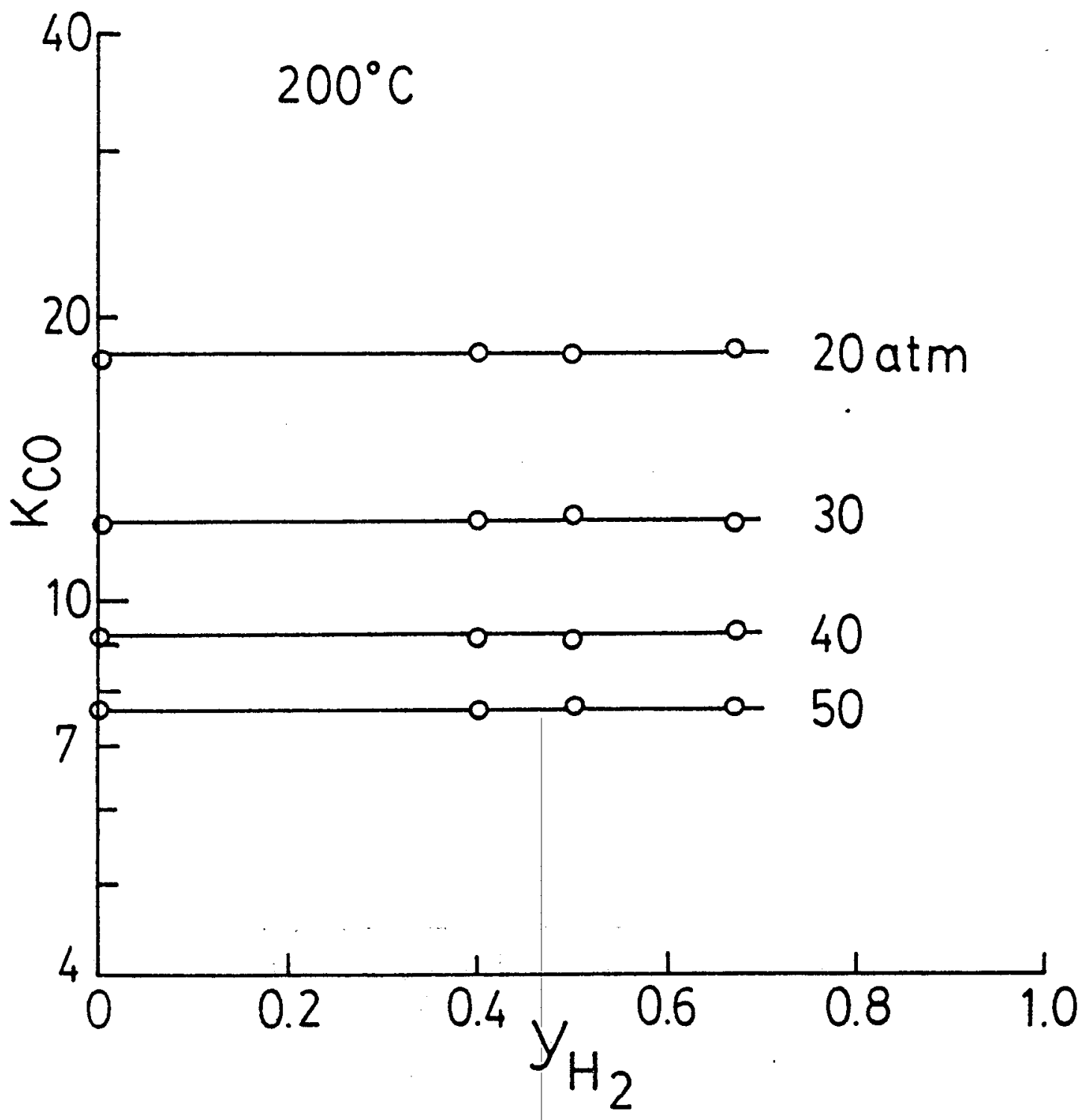

Figure 26. K-values of $\mathrm{CO}$ in $\mathrm{H}_{2}+\mathrm{CO}$ Mixtures in n-Octacosane at $200^{\circ} \mathrm{C}$ 


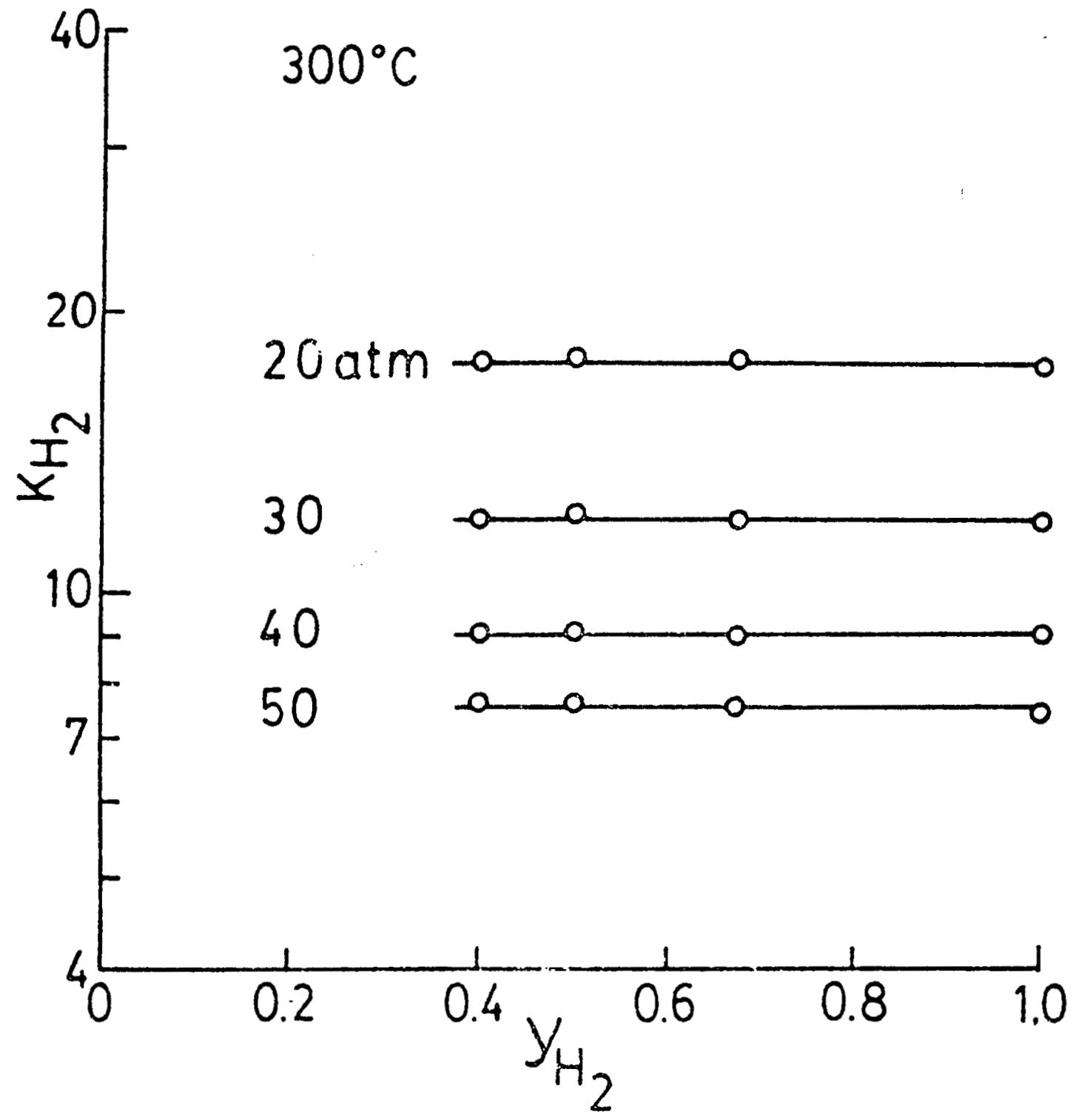

Figure 27. K-values of $\mathrm{H}_{2}$ in $\mathrm{H}_{2}+\mathrm{CO}$ Mixtures in n-Octacosane at $300^{\circ} \mathrm{C}$ 


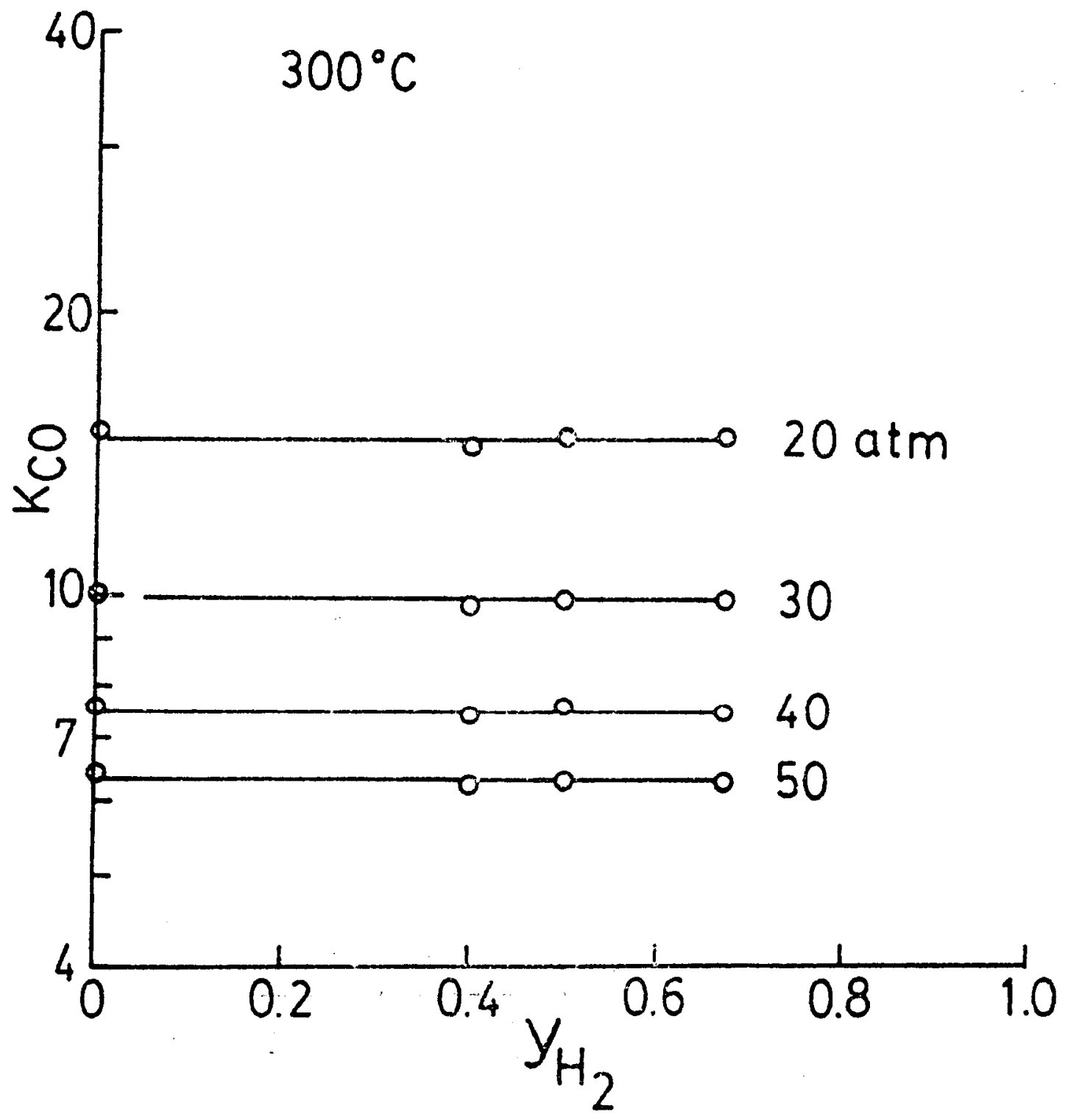

Figure 28. $\mathrm{K}$-values of $\mathrm{CO}$ in $\mathrm{H}_{2}+\mathrm{CO}$ Mixtures in n-Octacosane at $300^{\circ} \mathrm{C}$ 


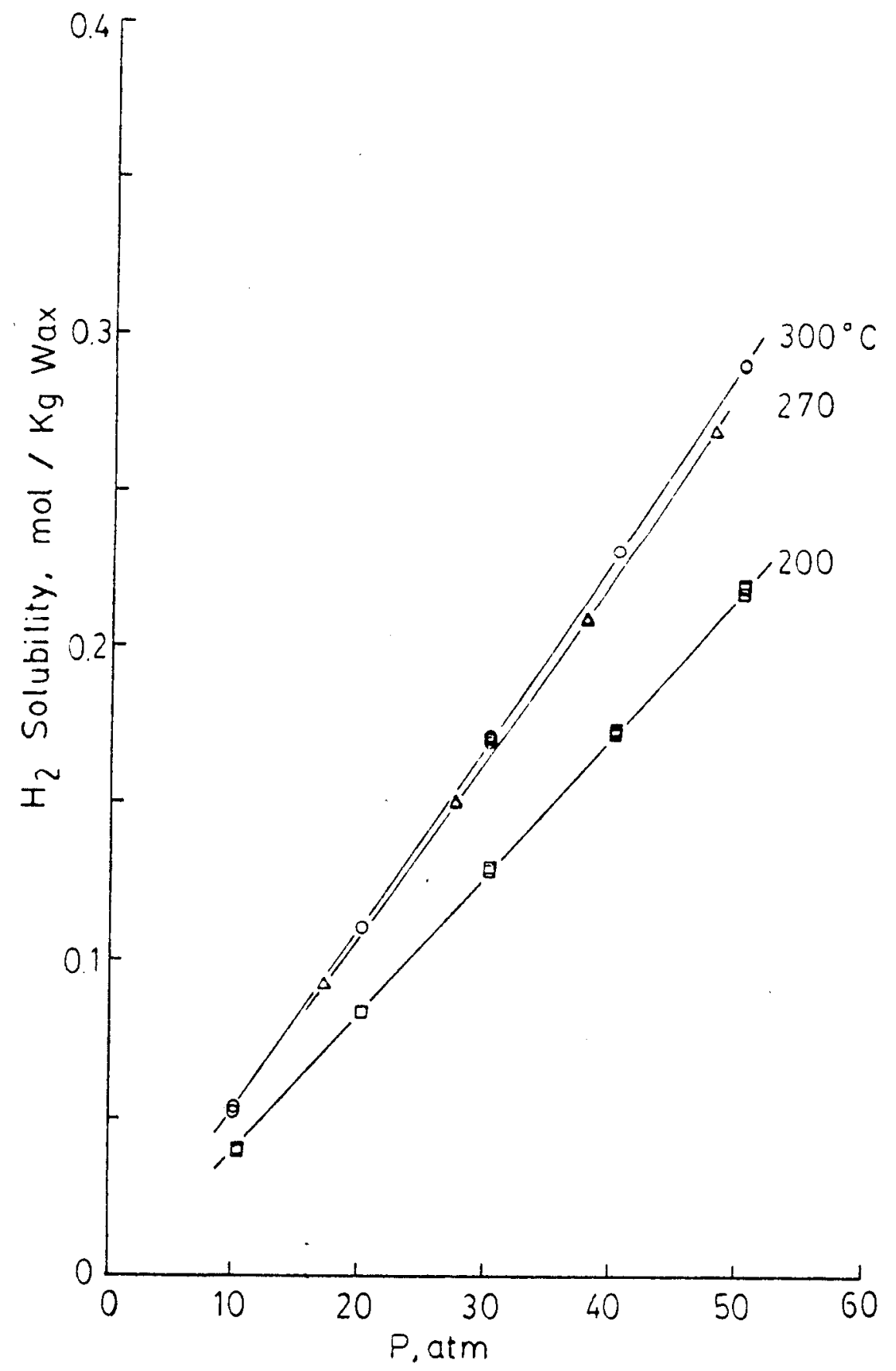

Figure 29. Solubility of Hydrogen in Mobil Wax 


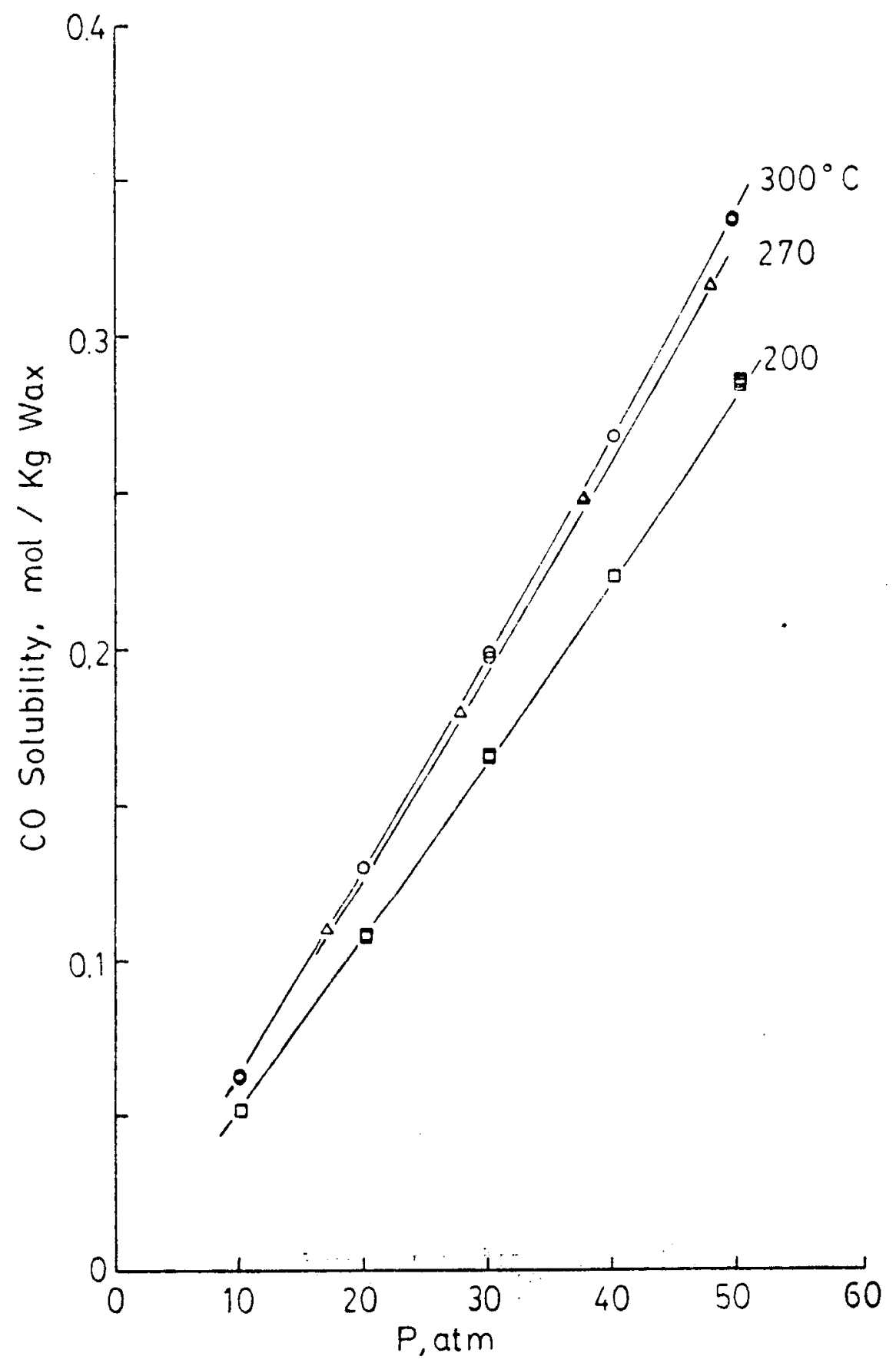

Figure 30. Solubility of Carbon Monoxide in Mobil Wax 


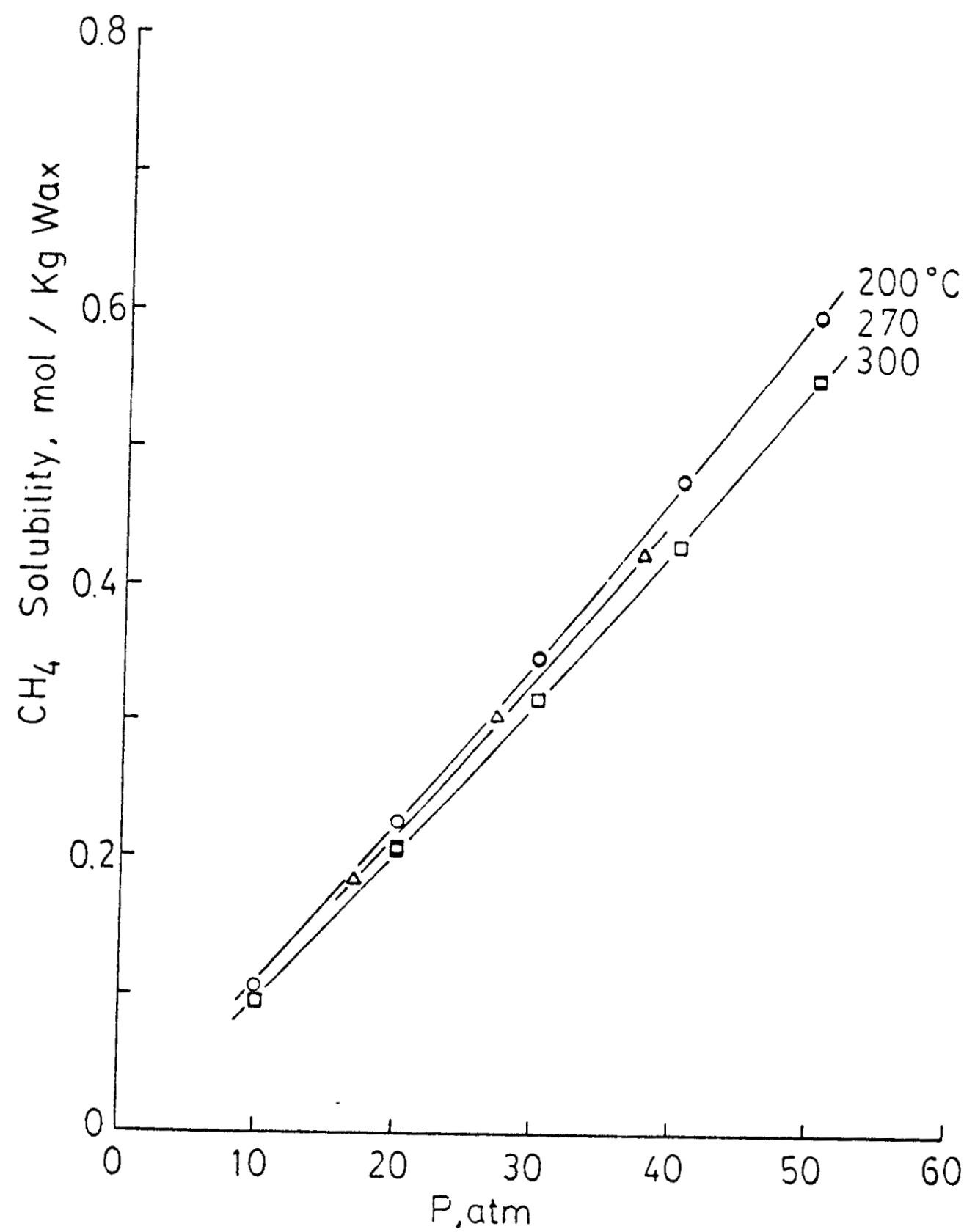

Figure 31. Solubility of Methane in Mobil Wax 


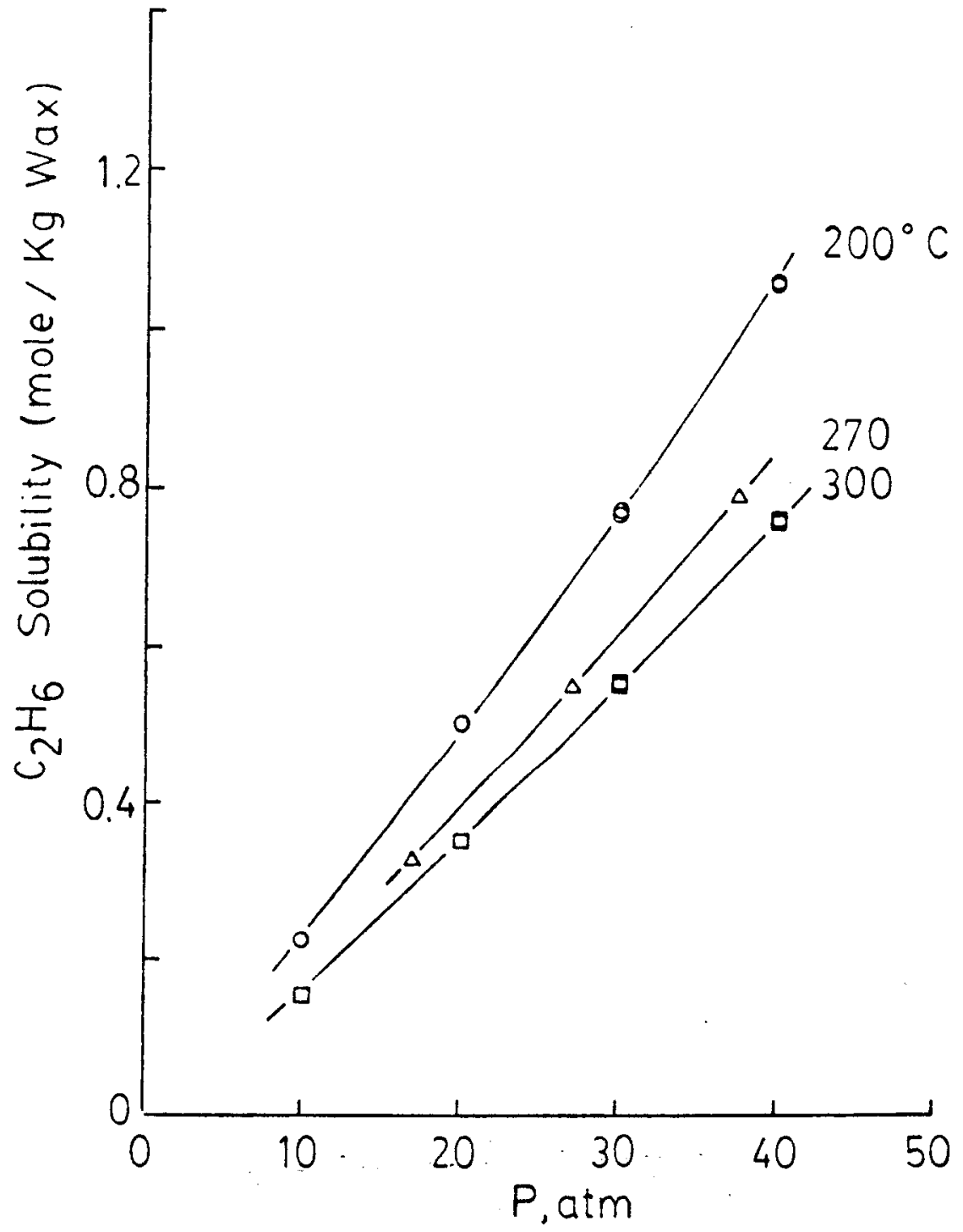

Figure 32. Solubility of Ethane in Mobil Wax 


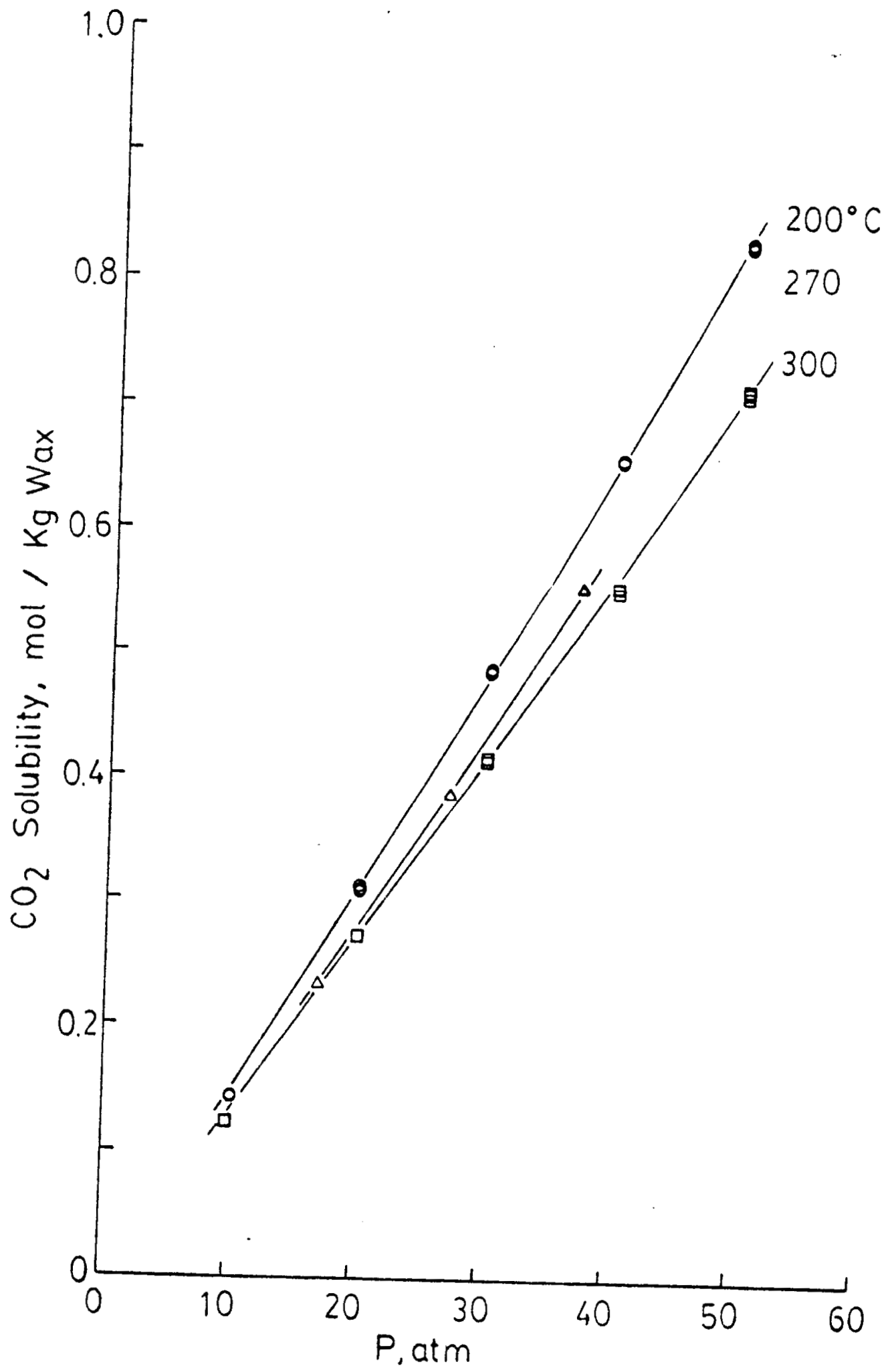

Figure 33. Solubility of Carbon Dioxide in Mobil Wax 


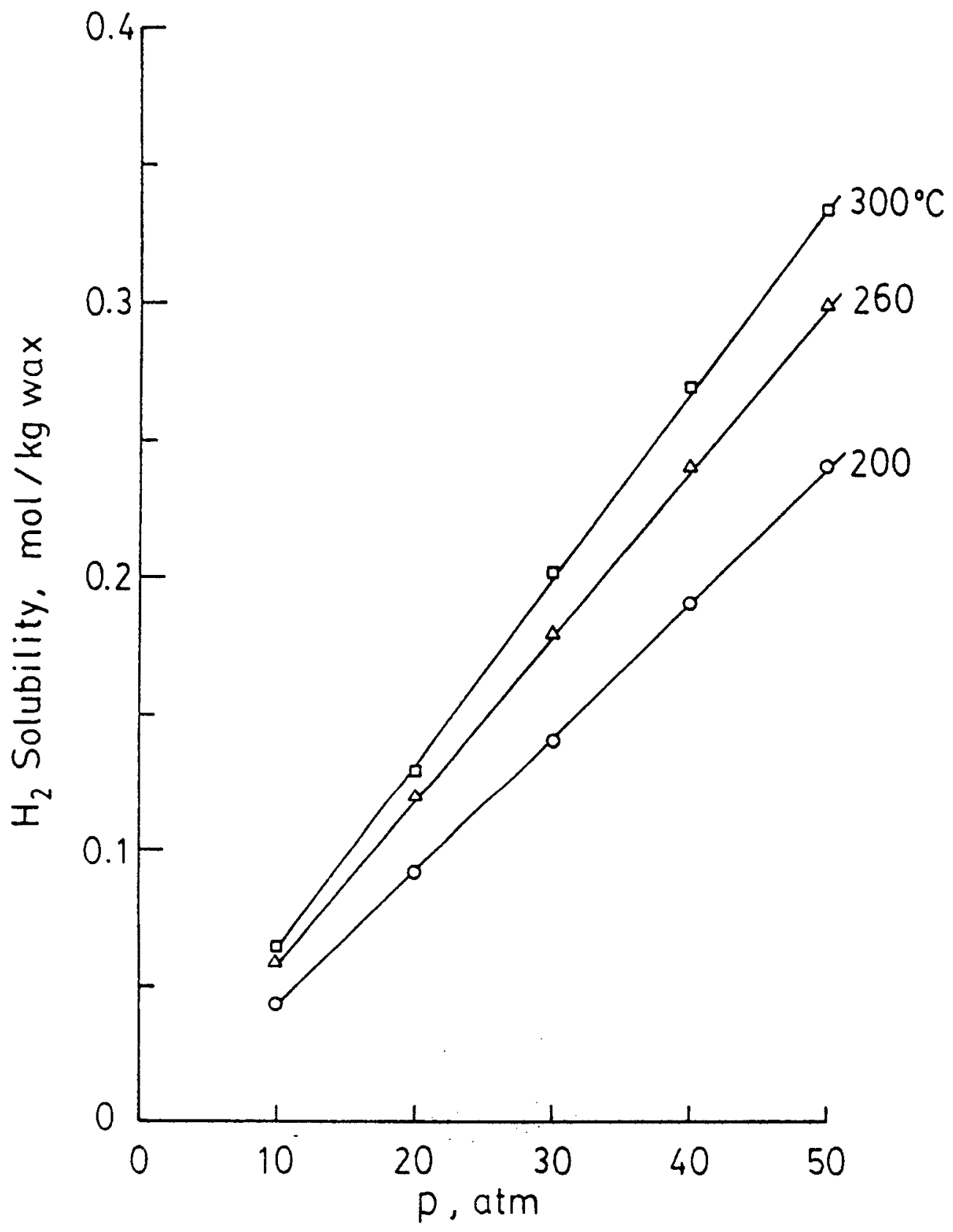

Figure 34. Solubility of Hydrogen in SASOL Wax 


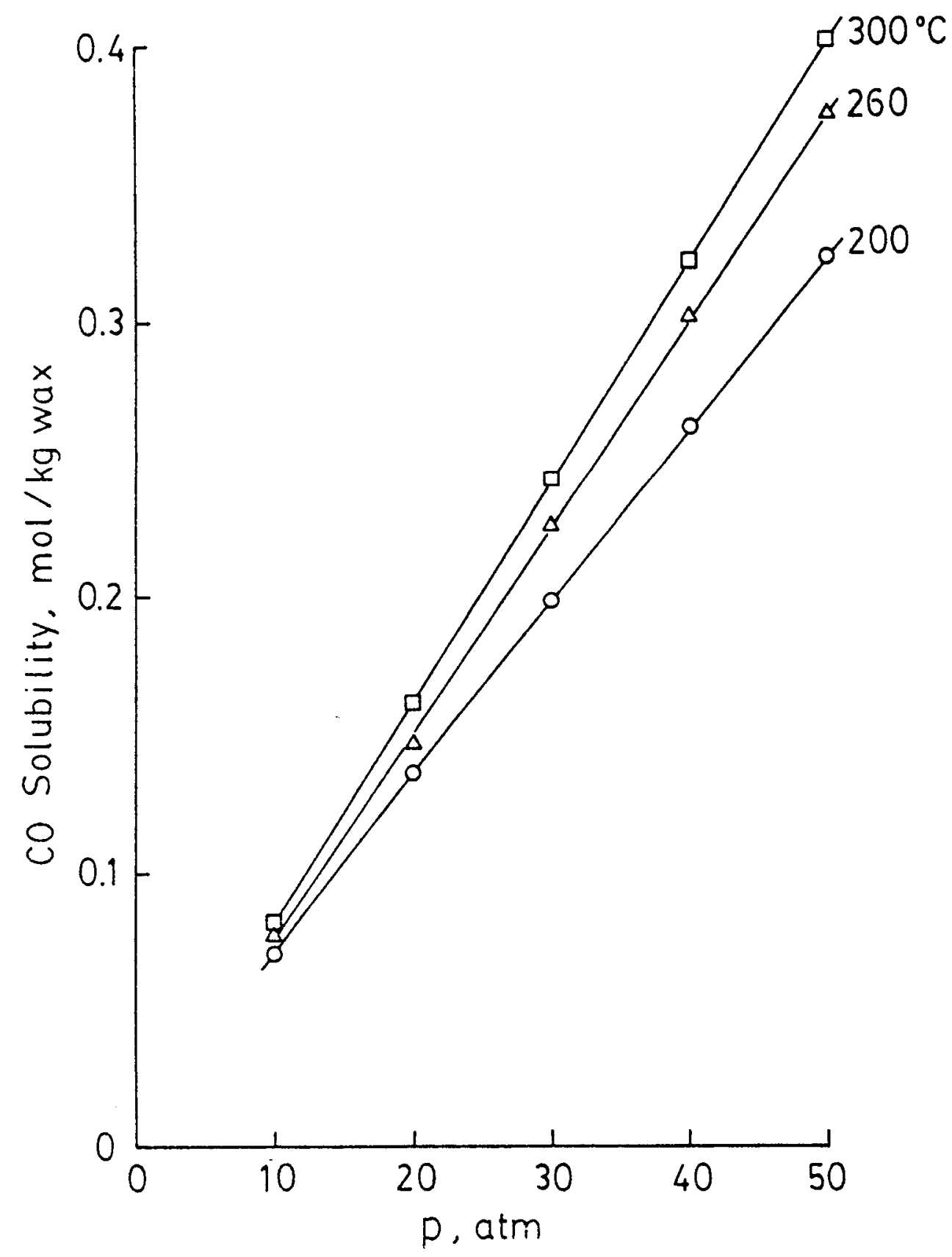

Figure 35. Solubility of Carbon Monoxide in SASOL Wax 


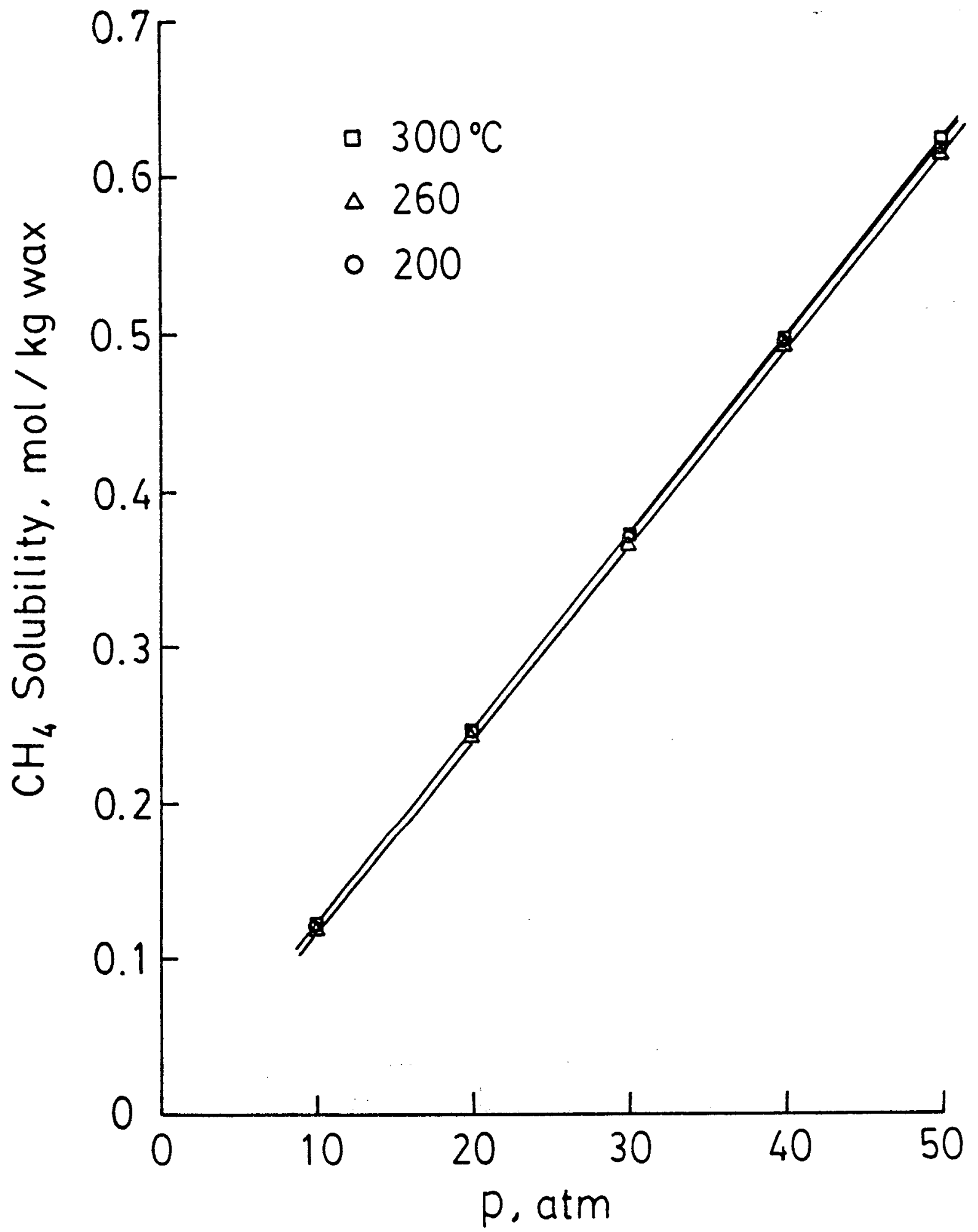

Figure 36. Solubility of Methane in SASOL Wax 


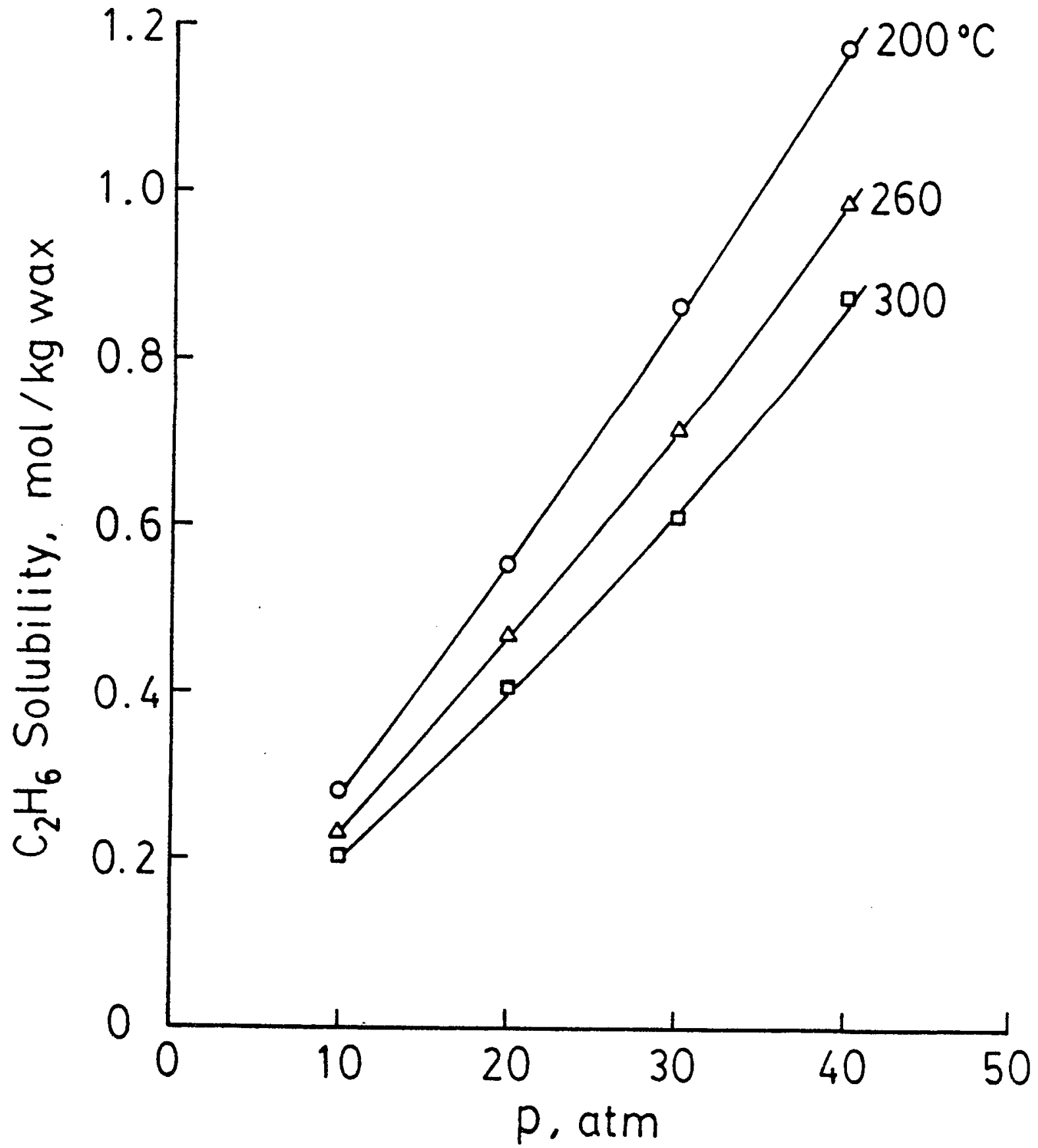

Figure 37. Solubility of Ethane in SASOL Wax 


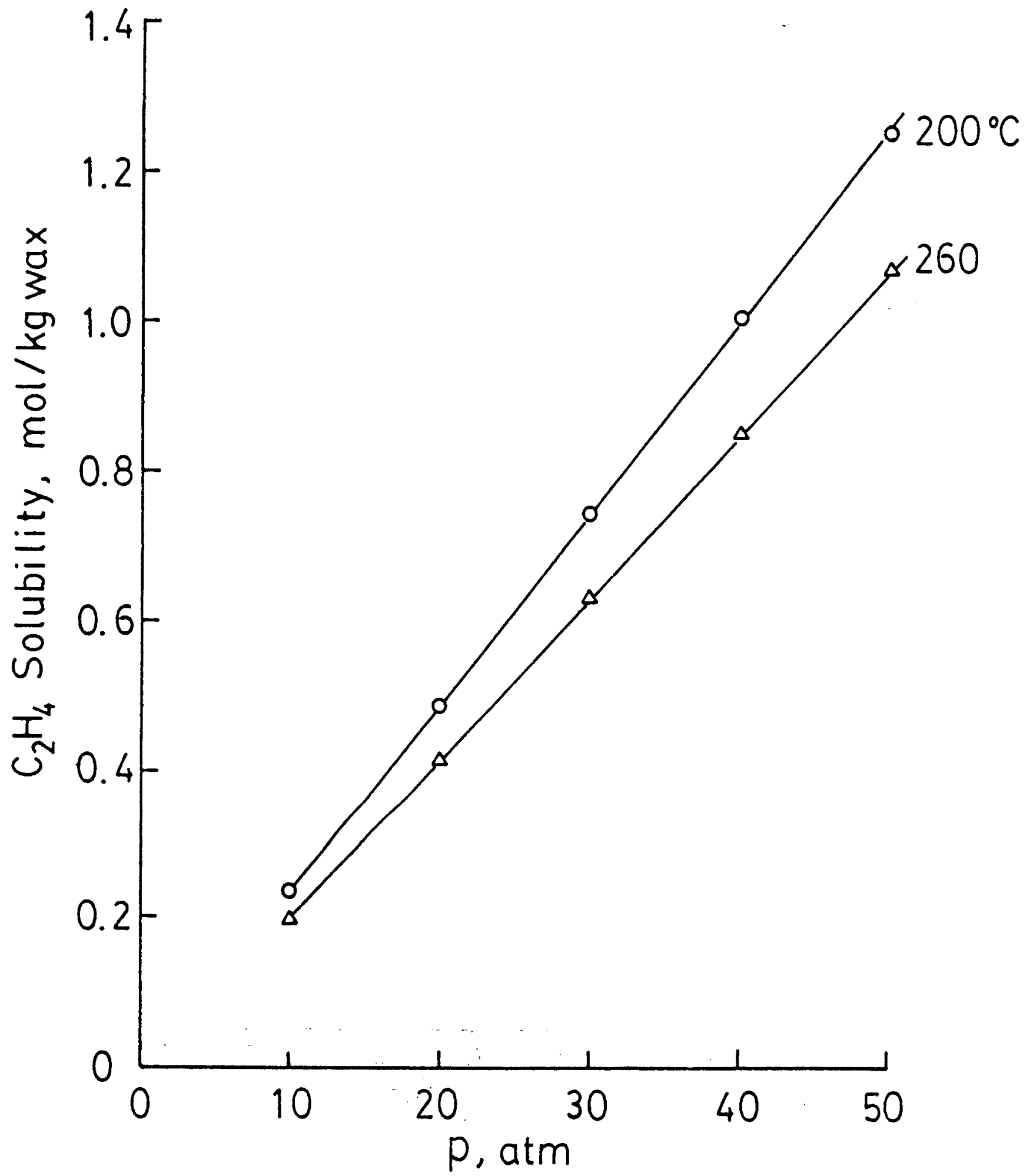

Figure 38. Solubility of Ethylene in SASOL Wax 


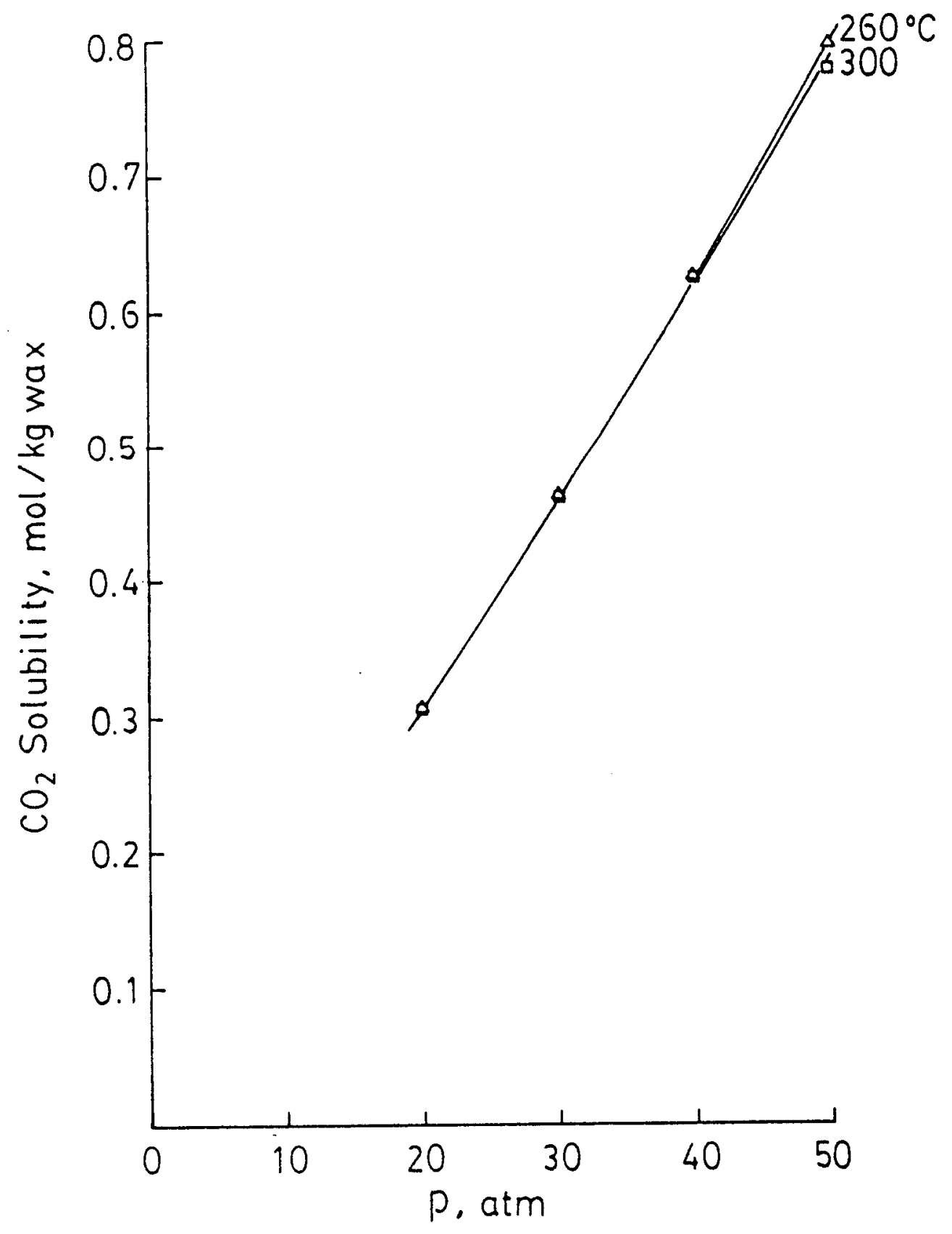

Figure 39. Solubility of Carbon Dioxide in SASOL Wax 


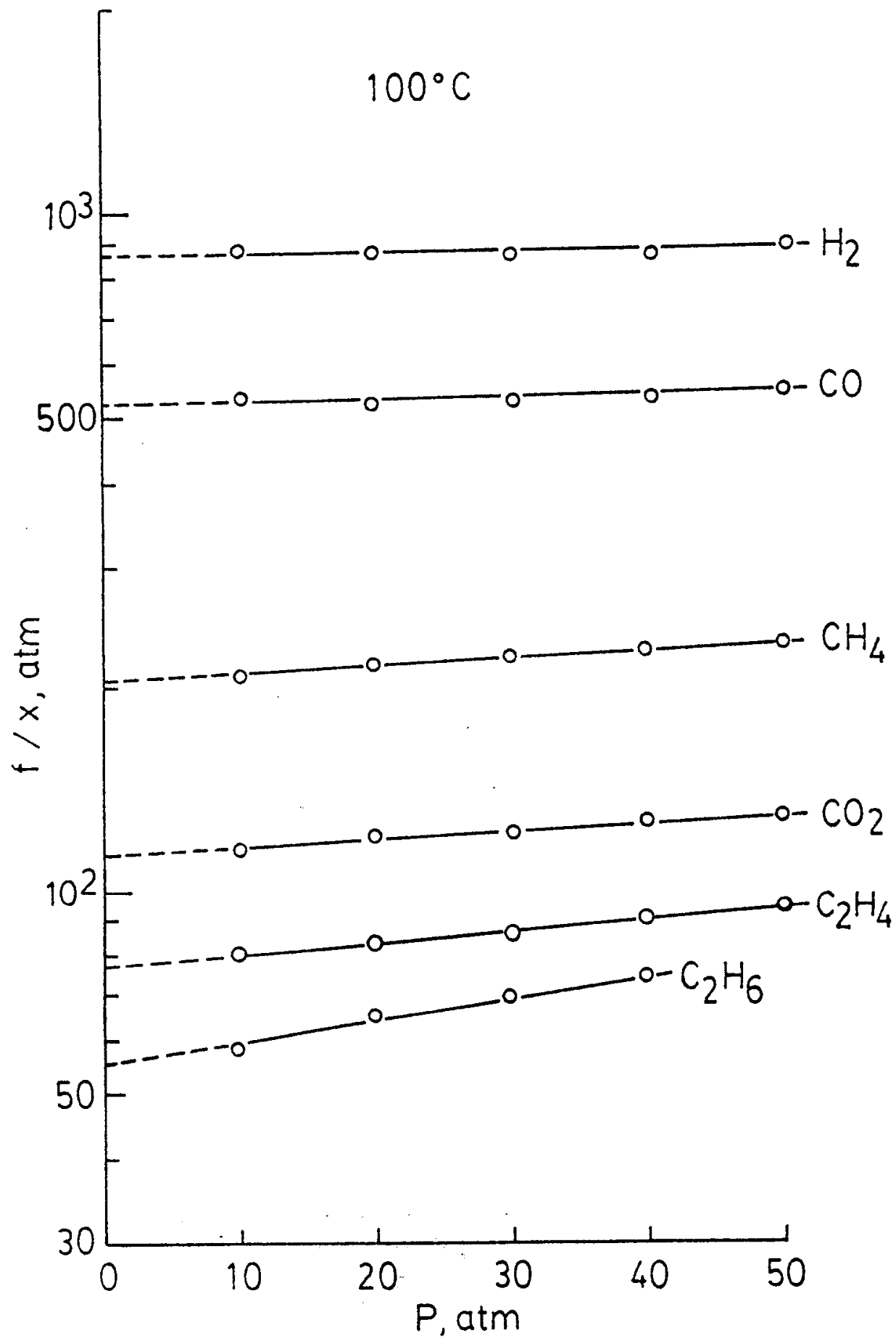

Figure 40. Correlation with Krichevsky-Kasarnovsky Equation for n-Eicosane mixtures at $100^{\circ} \mathrm{C}$ 


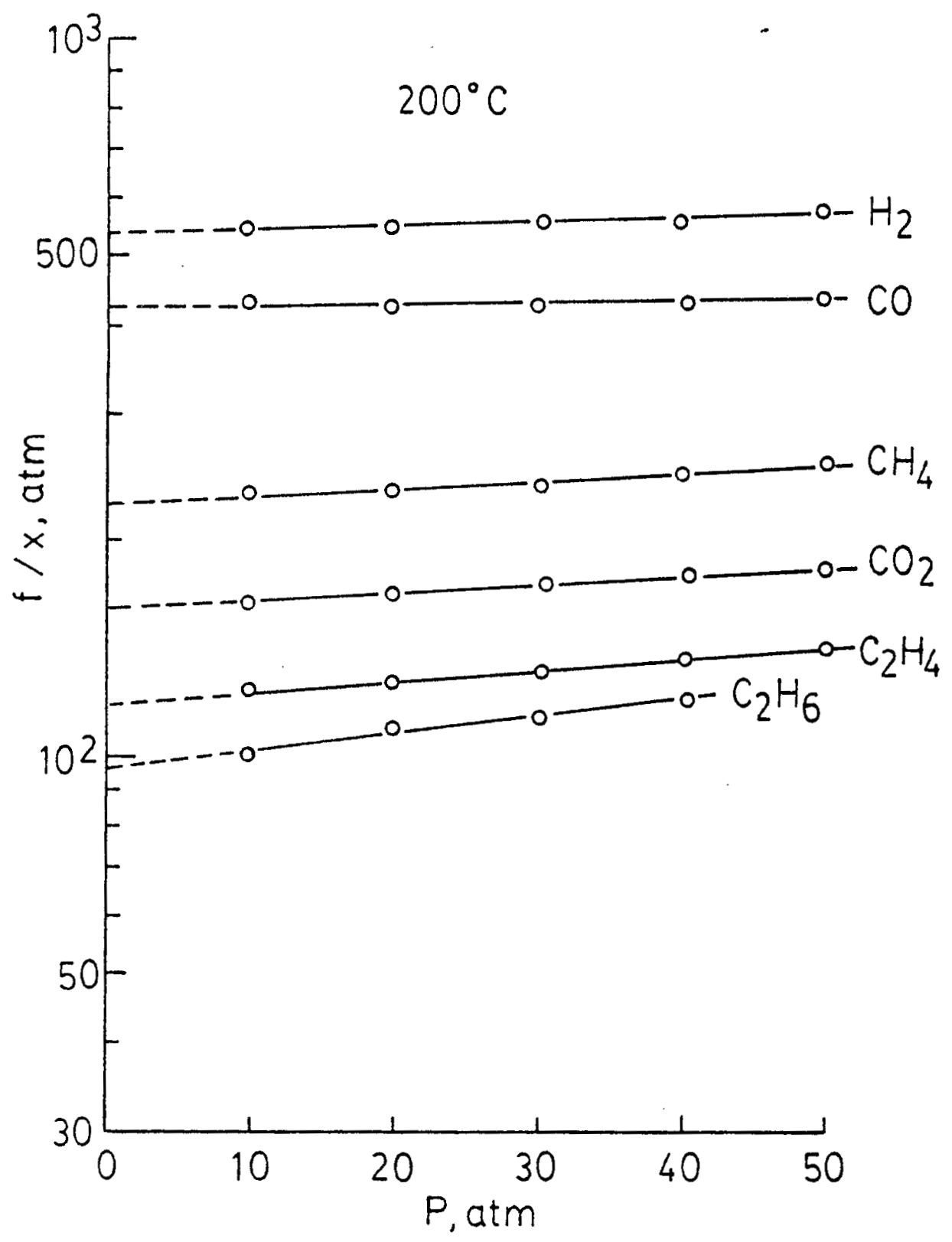

Figure 41. Correlation with Krichevsky-Kasarnovsky Equation for n-Eicosane mixtures at $200^{\circ} \mathrm{C}$ 


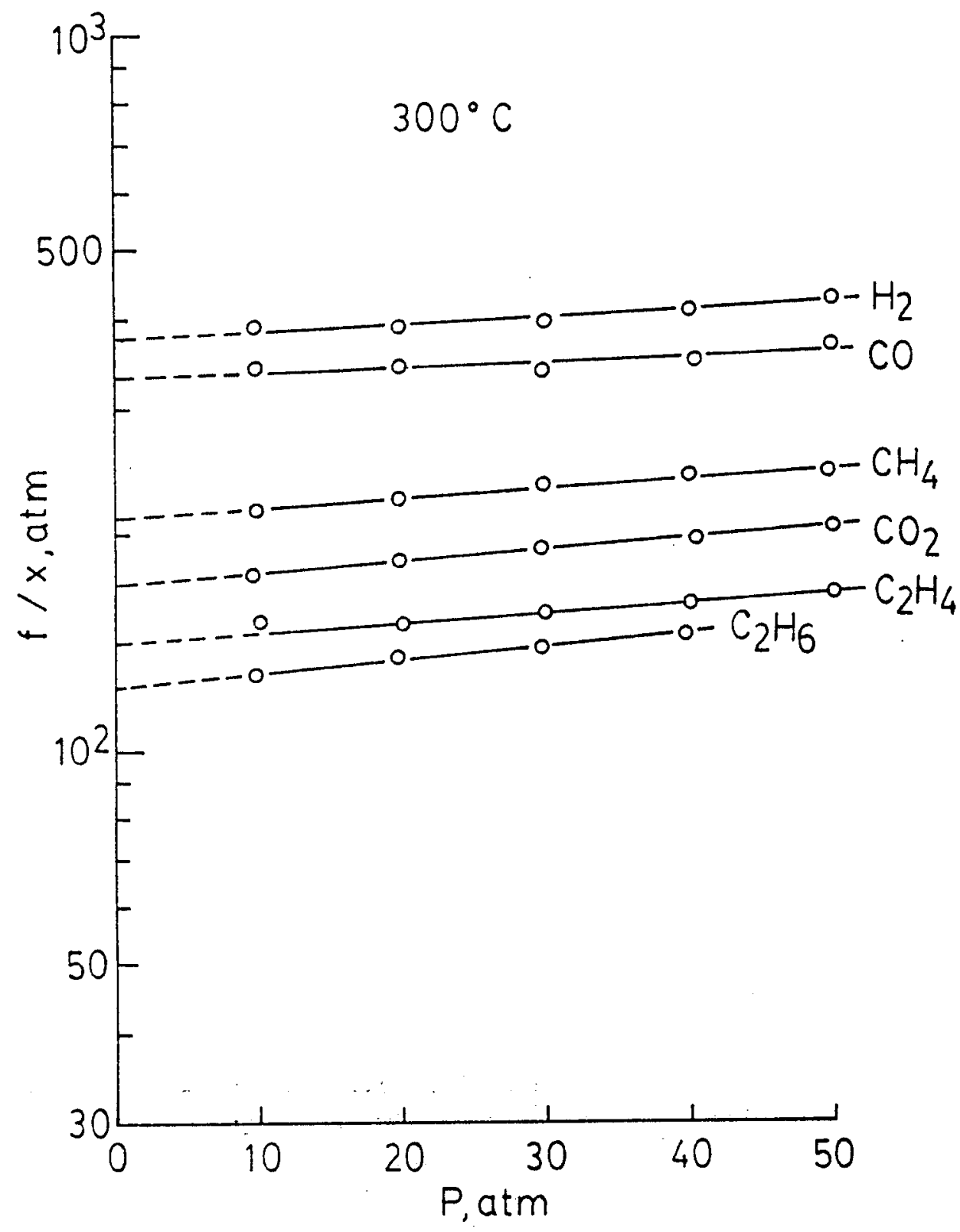

Figure 42. Correlation with Krichevsky-Kasarnovsky Equation for n-Eicosane mixtures at $300^{\circ} \mathrm{C}$ 


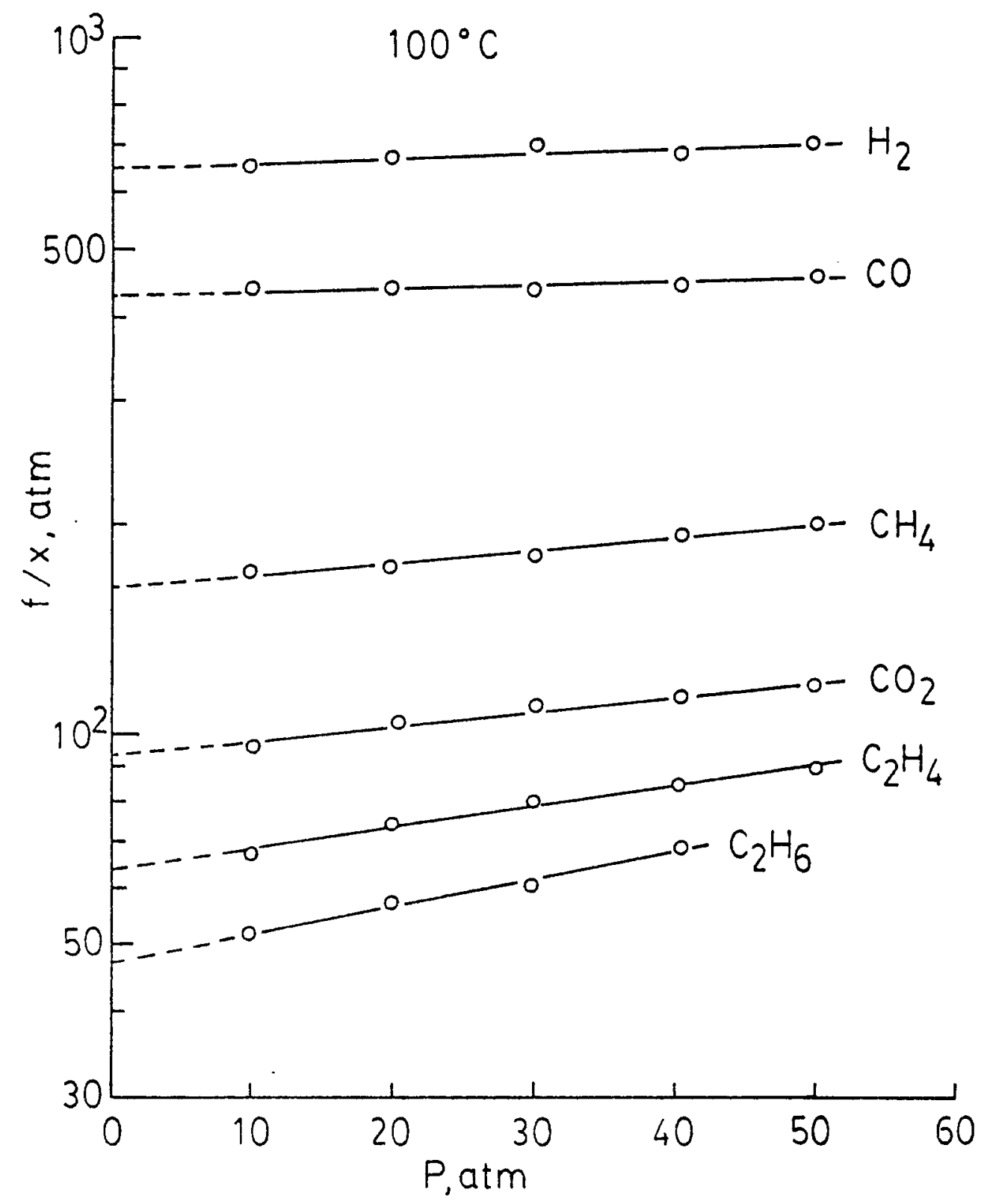

Figure 43. Correlation with Krichevsky-Kasarnovsky Equation for n-Octacosane mixtures at $100^{\circ} \mathrm{C}$ 


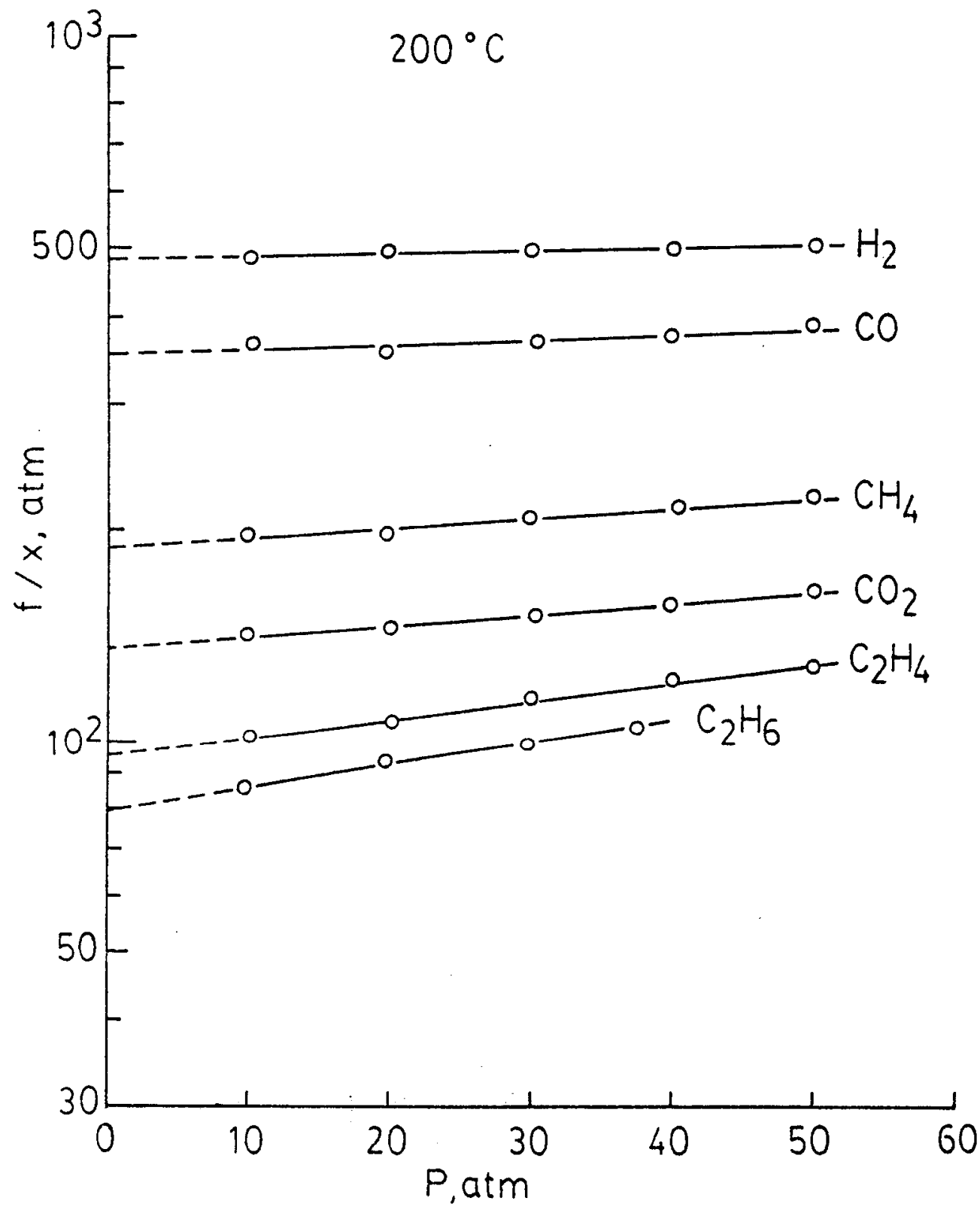

Figure 44. Correlation with Krichevsky-Kasarnovsky Equation for n-Octacosane mixtures at $200^{\circ} \mathrm{C}$ 


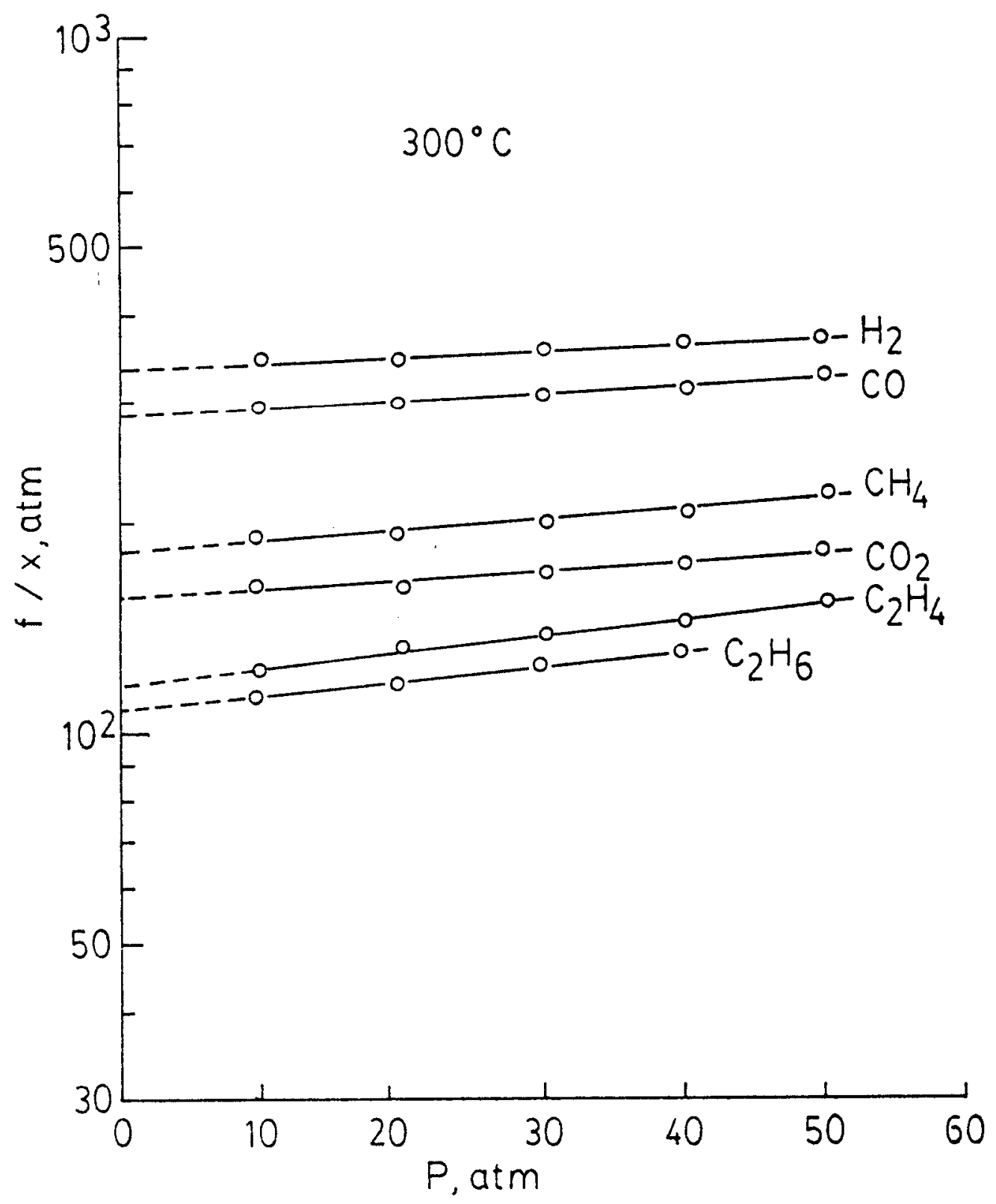

Figure 45. Correlation with Krichevsky-Kasarnovsky Equation for n-Octacosane mixtures at $300^{\circ} \mathrm{C}$ 


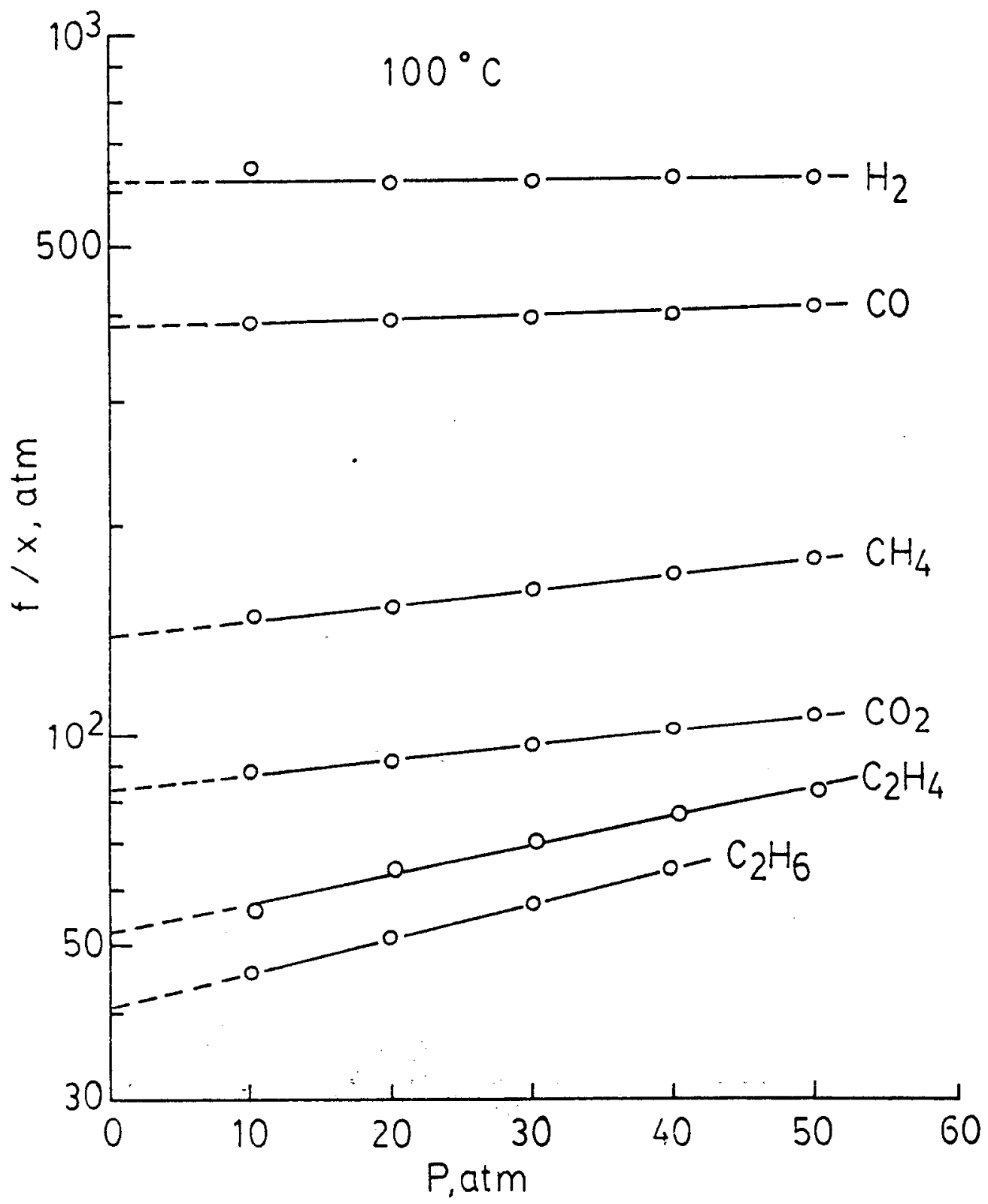

Figure 46. Correlation with Krichevsky-Kasarnovsky Equation for nHexatriacotane at $100^{\circ} \mathrm{C}$ 


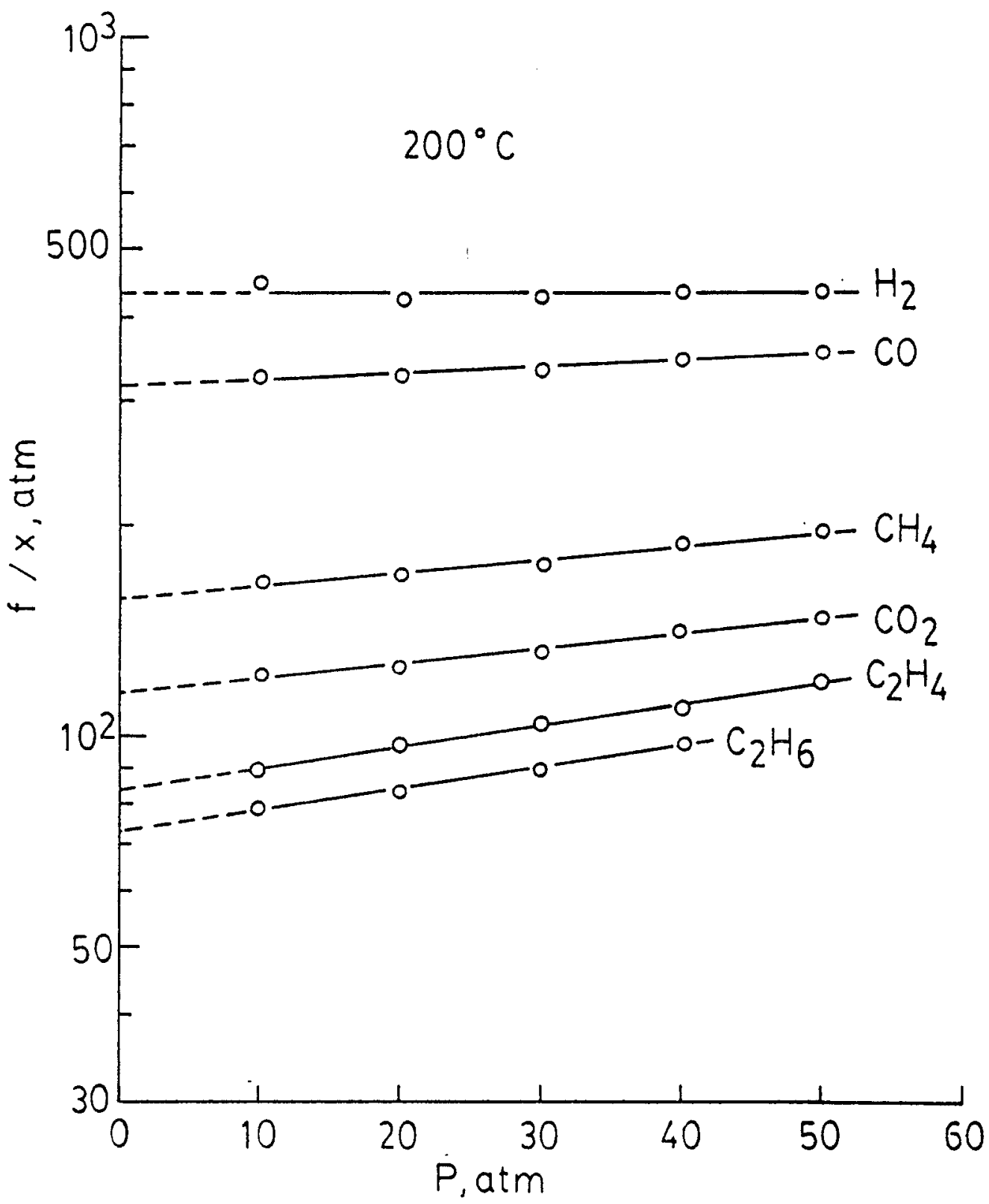

Figure 47. Correlation with Krichevsky-Kasarnovsky Equation for nHexatriacotane at $200^{\circ} \mathrm{C}$ 


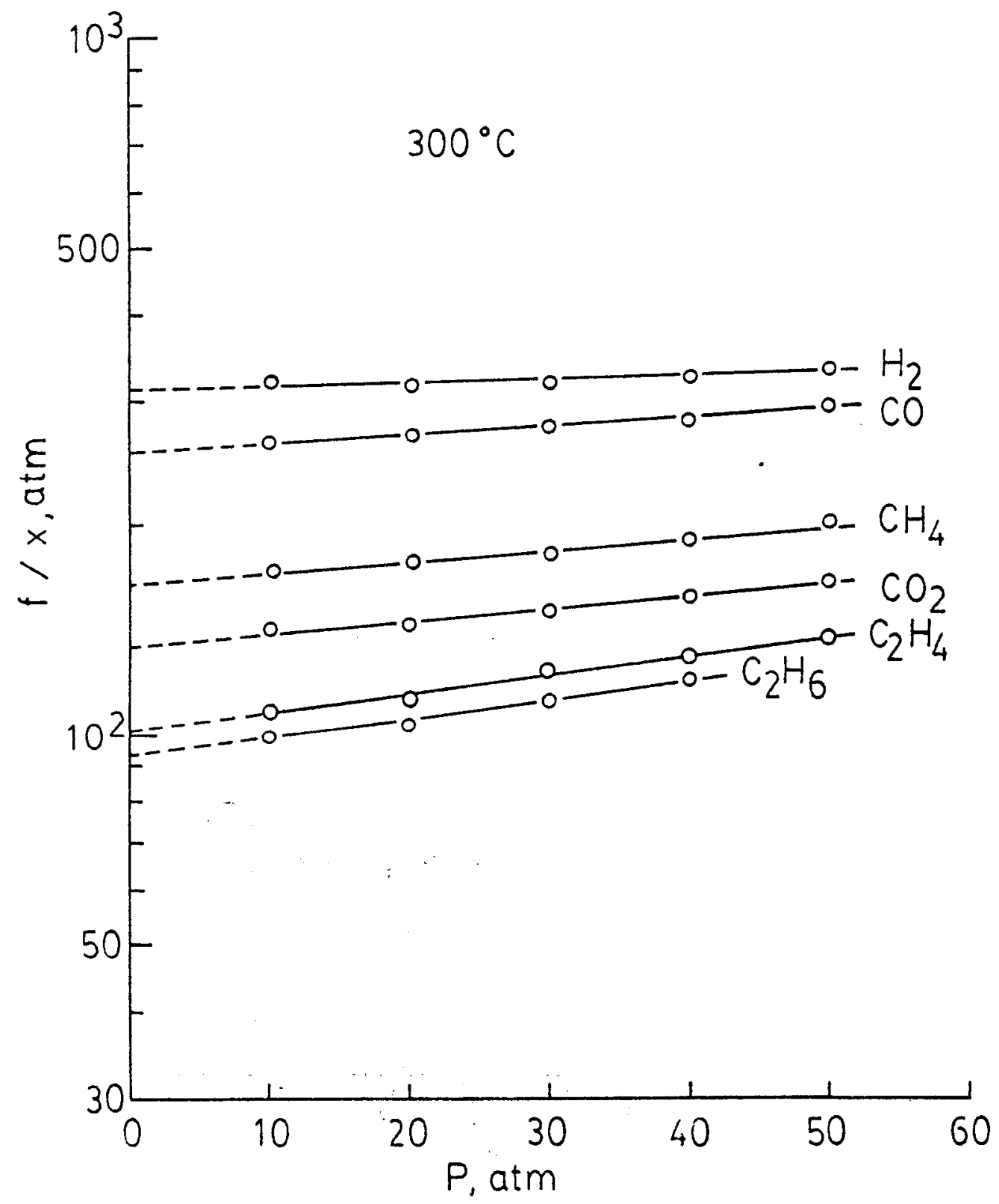

Figure 48. Correlation with Krichevsky-Kasarnovsky Equation for nHexatriacotane at $300^{\circ} \mathrm{C}$ 


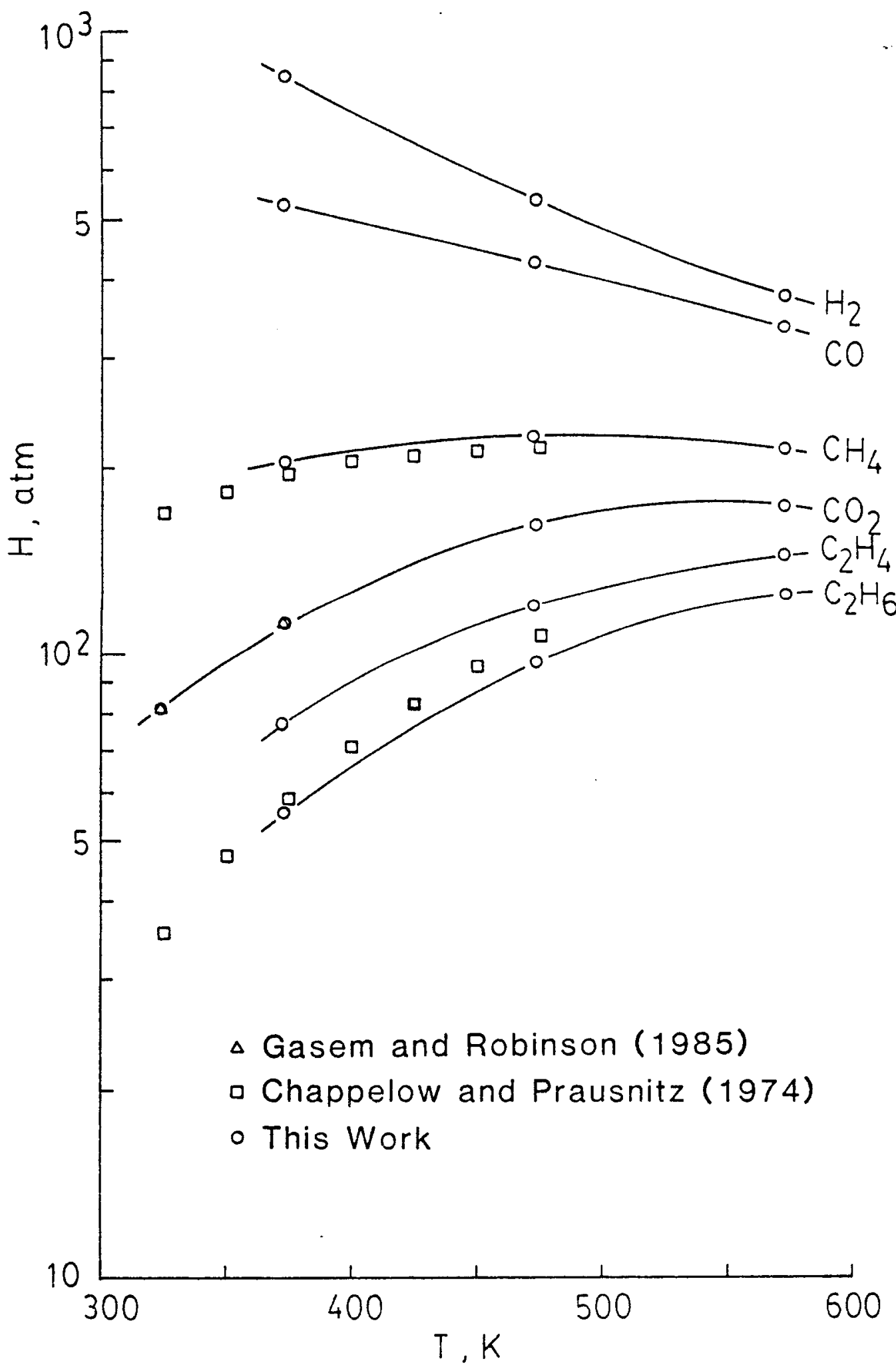

Figure 49. Henry's Constants in n-Eicosane 


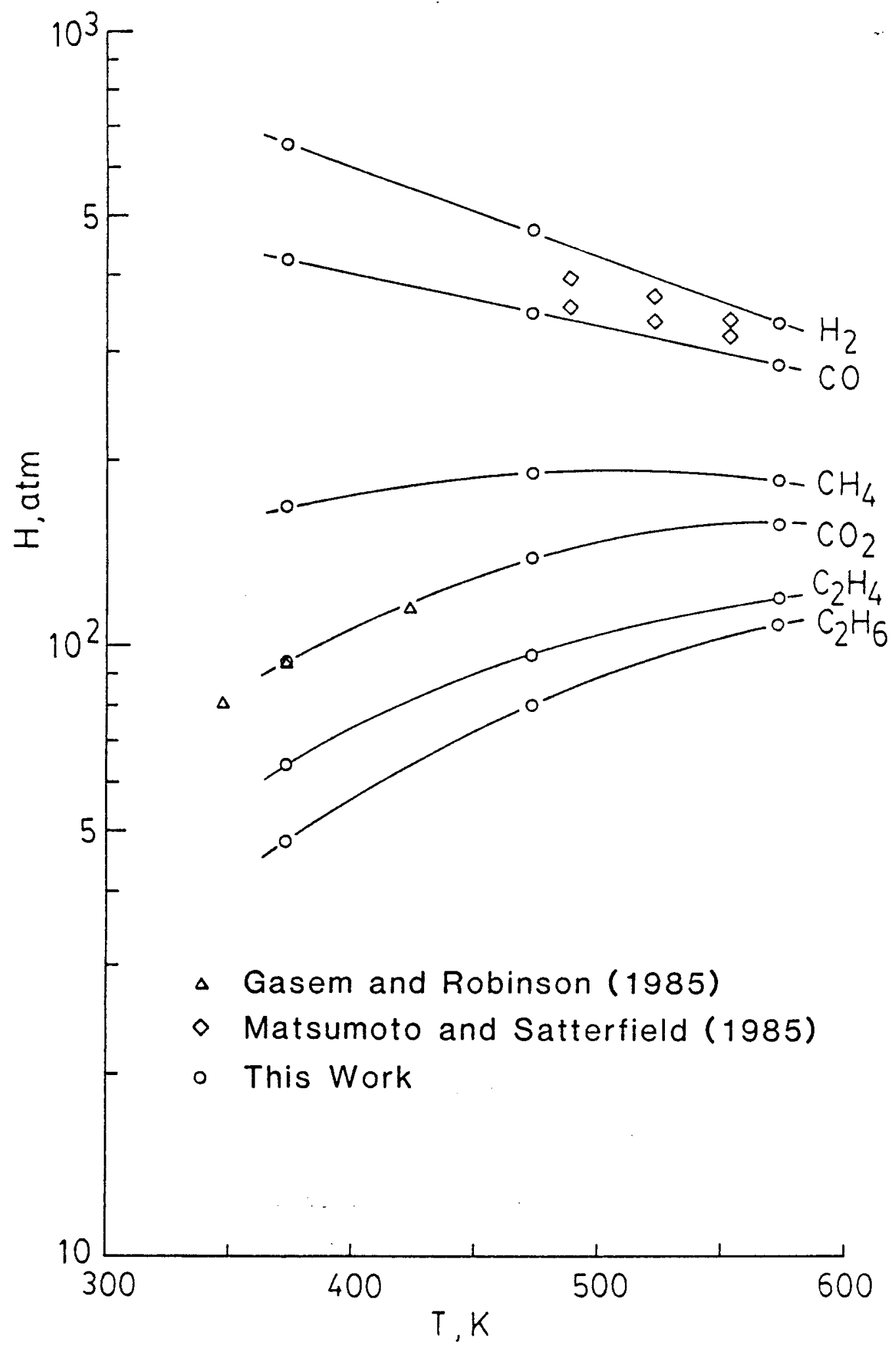

Figure 50. Henry's Constants in n-Octacosane 


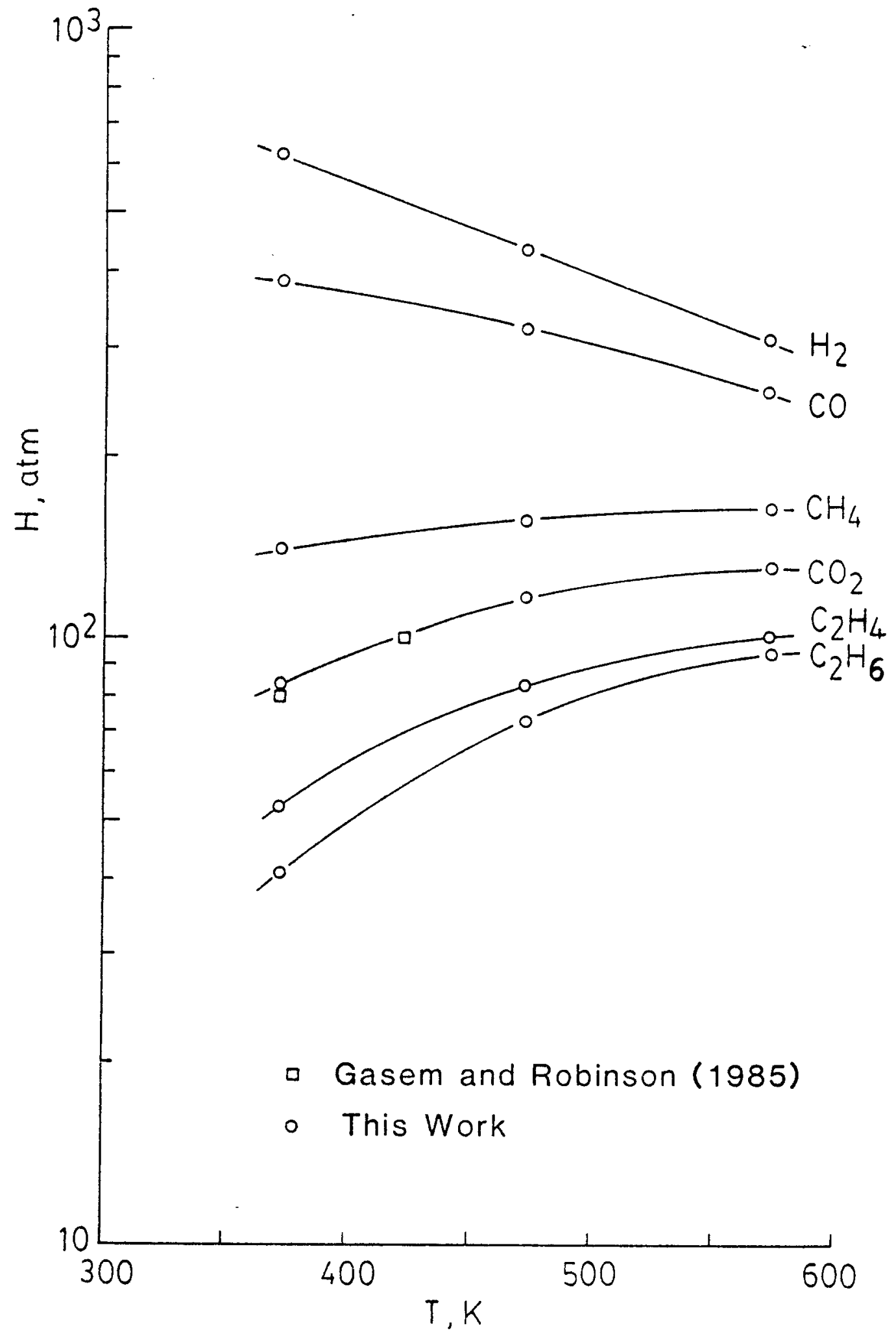

Figure 51. Henry's Constants in n-Hexatriacotane 


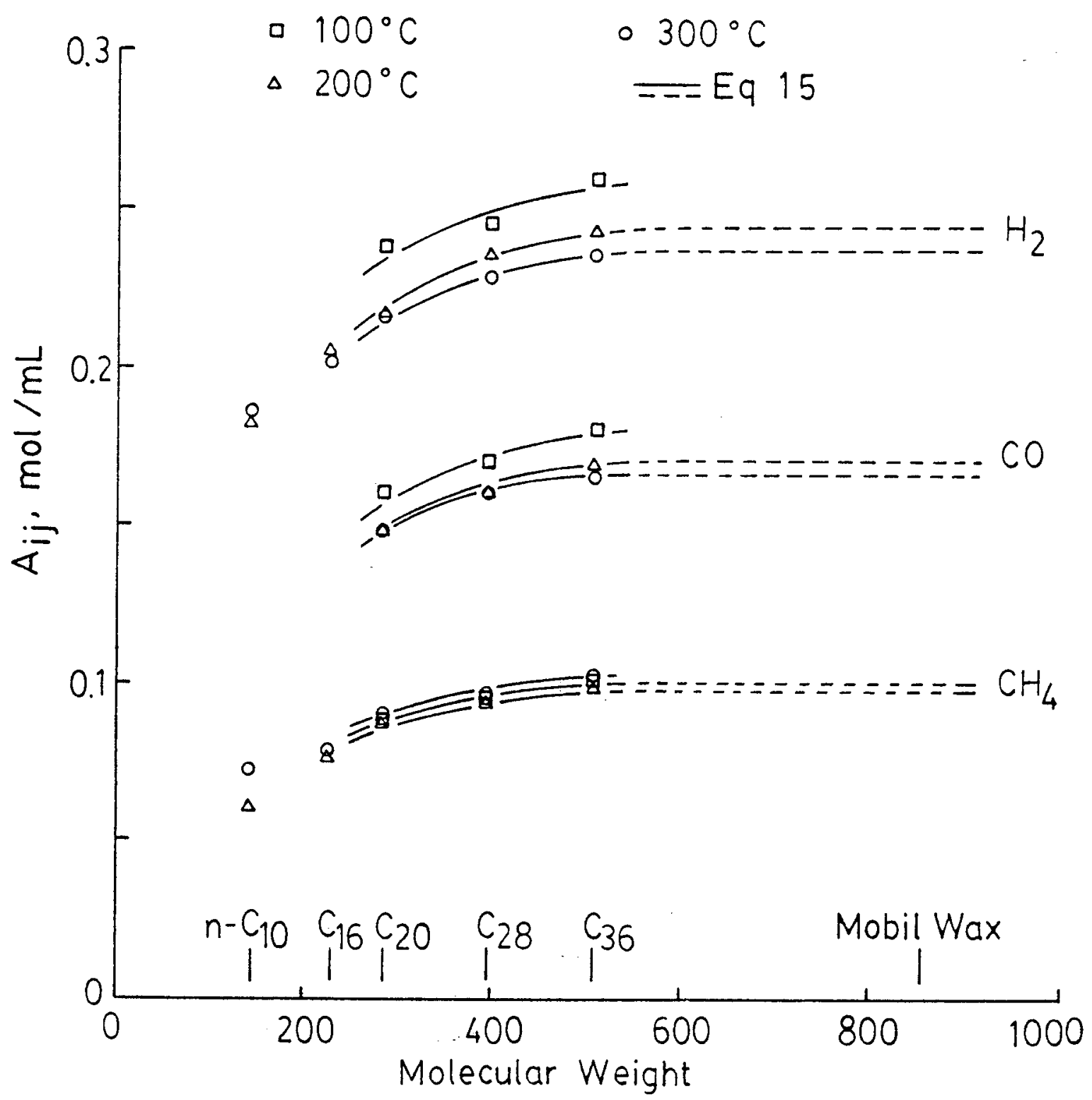

Figure 52. Plot of $A_{i j}$ vs Molecular Weight of n-Paraffins 


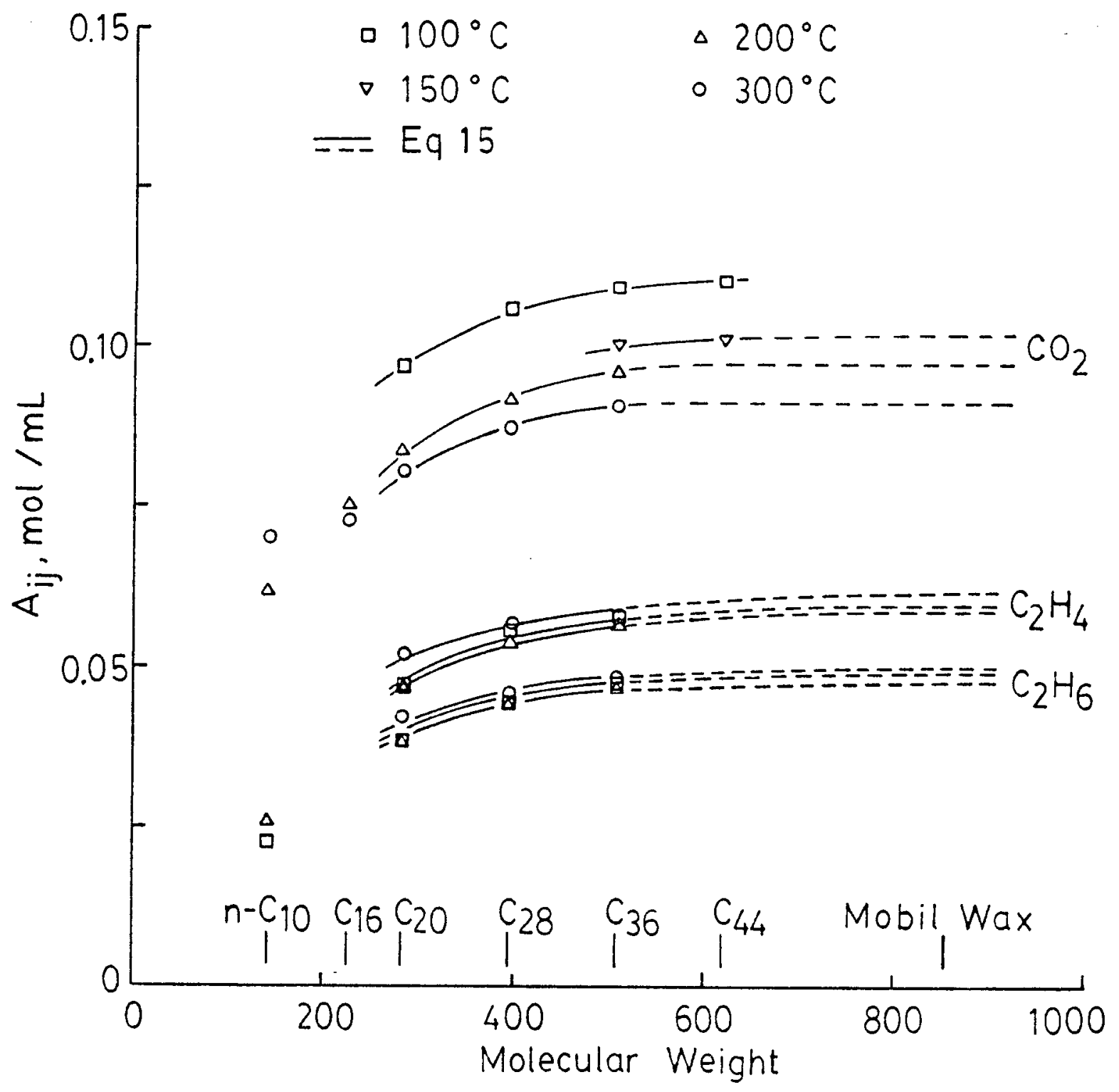

Figure 53. Plot of $\mathbf{A}_{\mathrm{ij}}$ vs Molecular Weight of n-Paraffins 


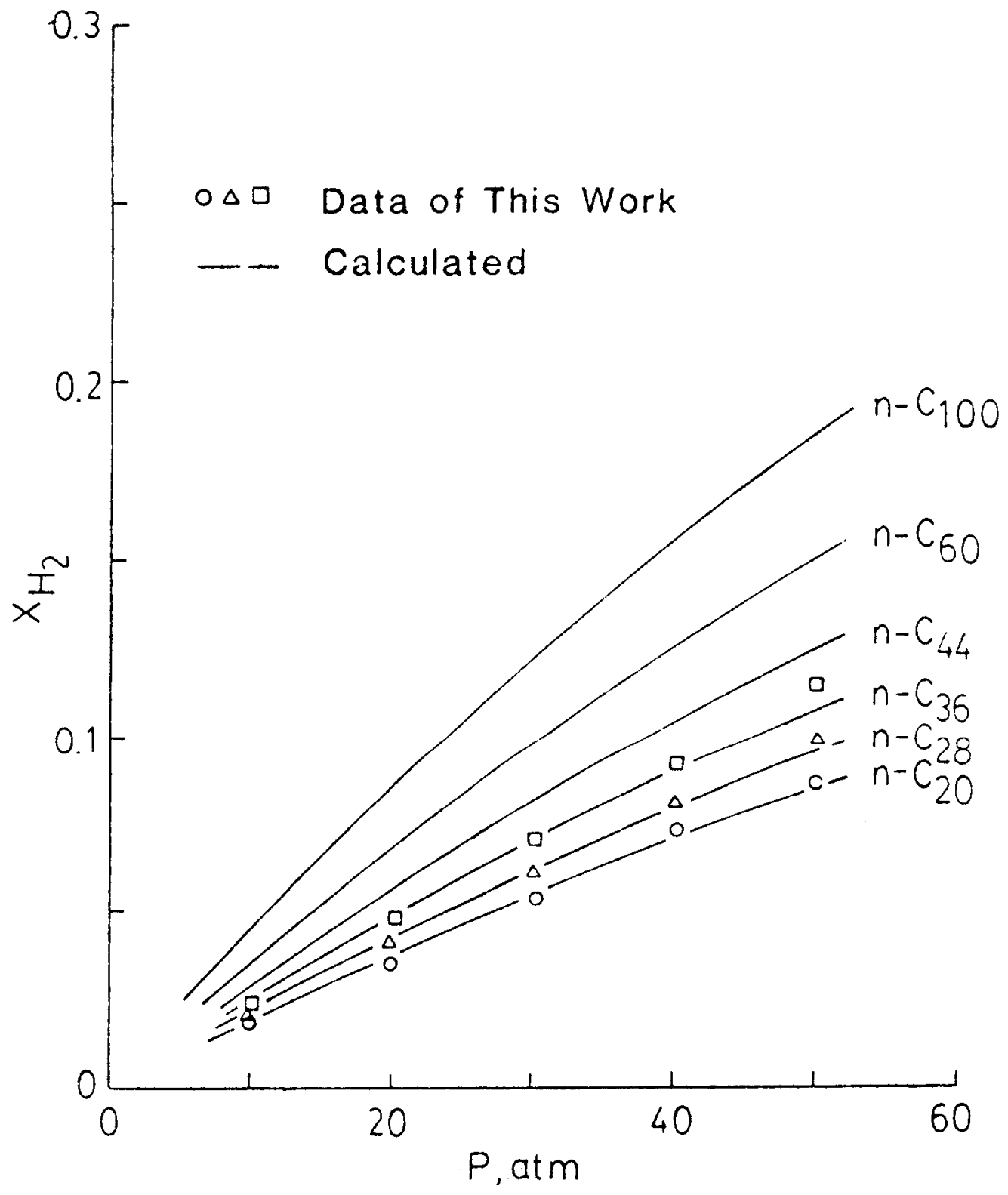

Figure 54. Calculated Hydrogen Solubilities in n-Paraffins at $200^{\circ} \mathrm{C}$ 


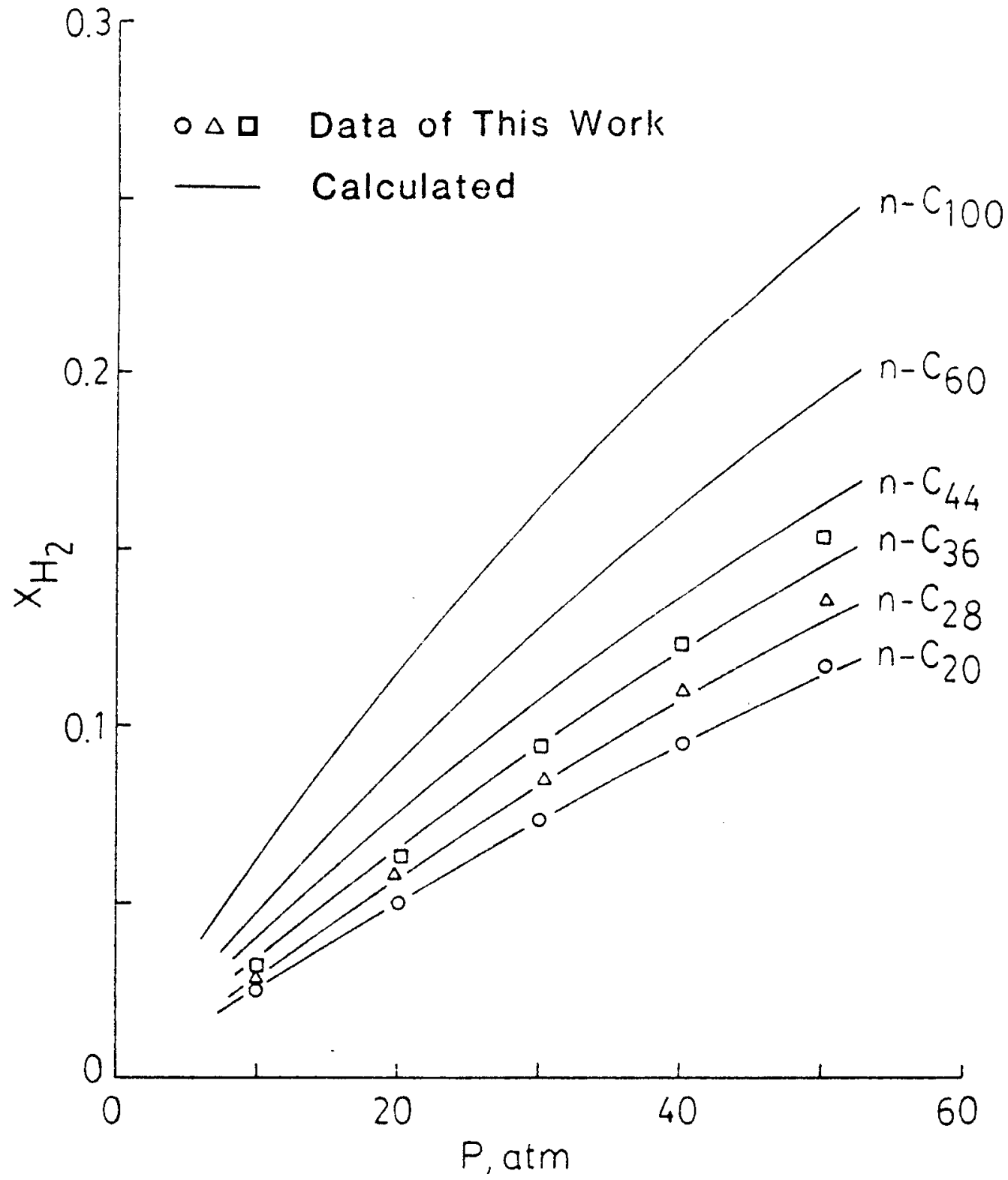

Figure 55. Calculated Hydrogen Solubilities in n-Paraffins at $300^{\circ} \mathrm{C}$ 


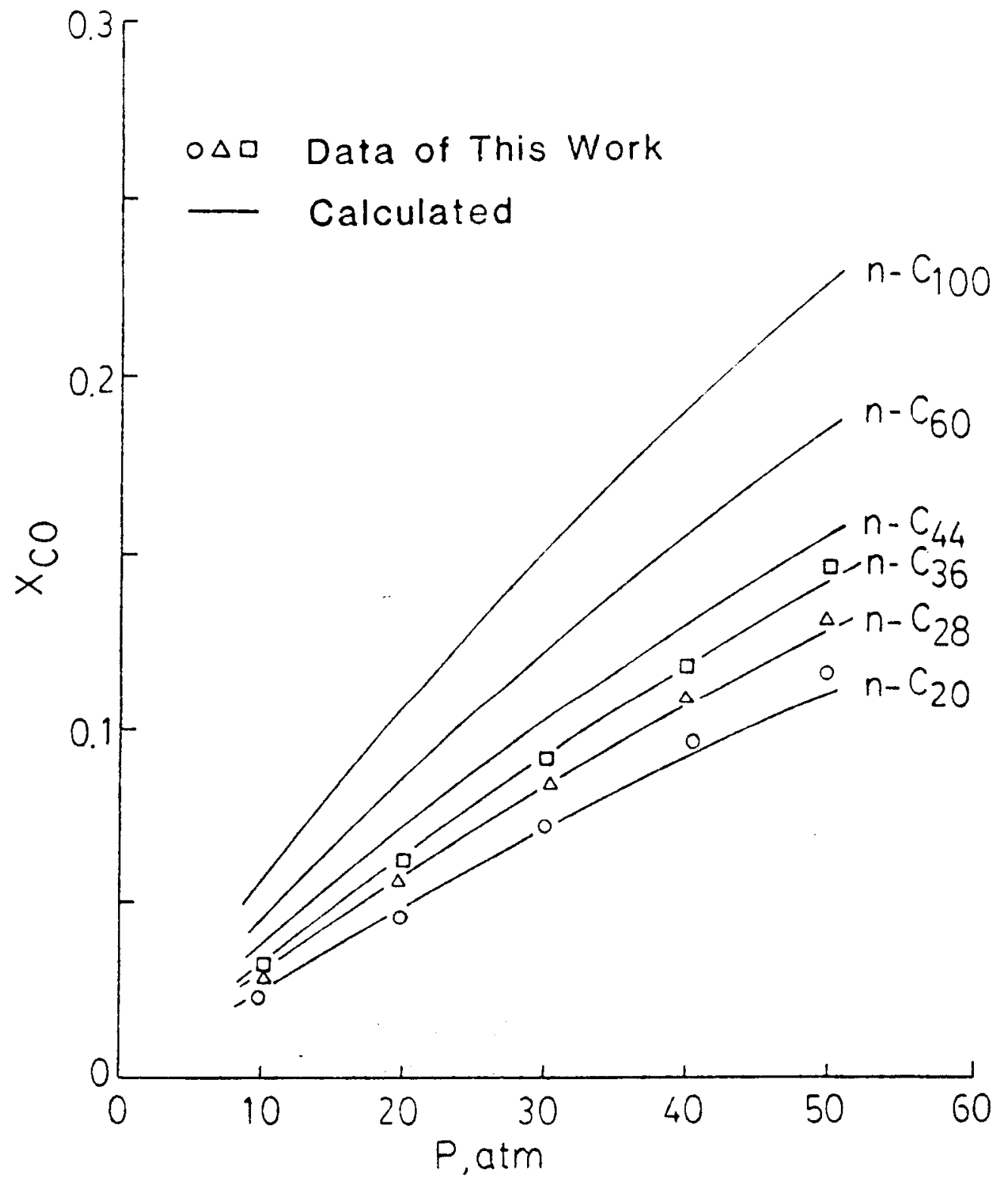

Figure 56. Calculated Carbon Monoxide Solubilities in n-Paraffins at $200^{\circ} \mathrm{C}$ 


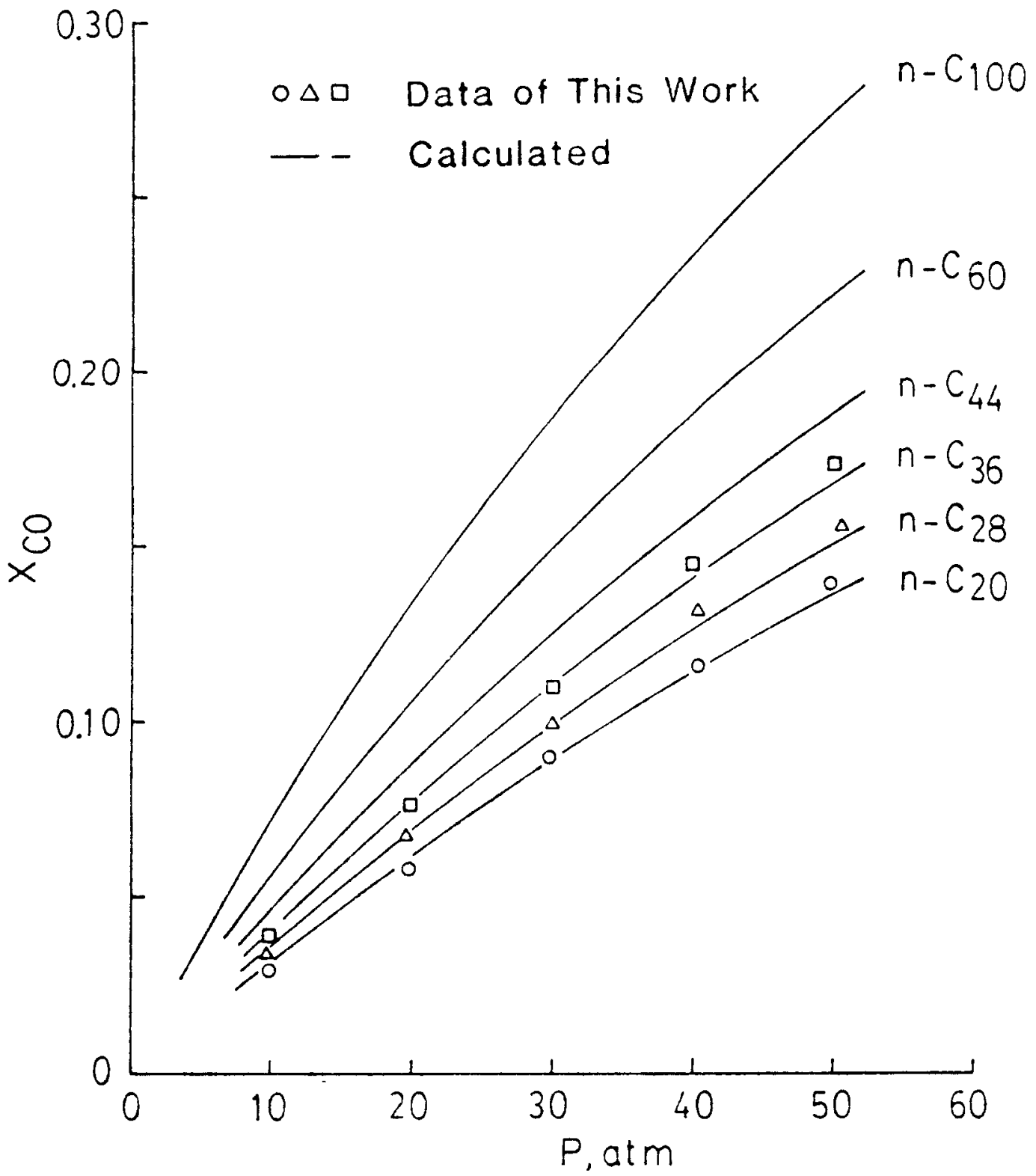

Figure 57. Calculated Carbon Monoxide Solubilities in n-Paraffins at $300^{\circ} \mathrm{C}$ 


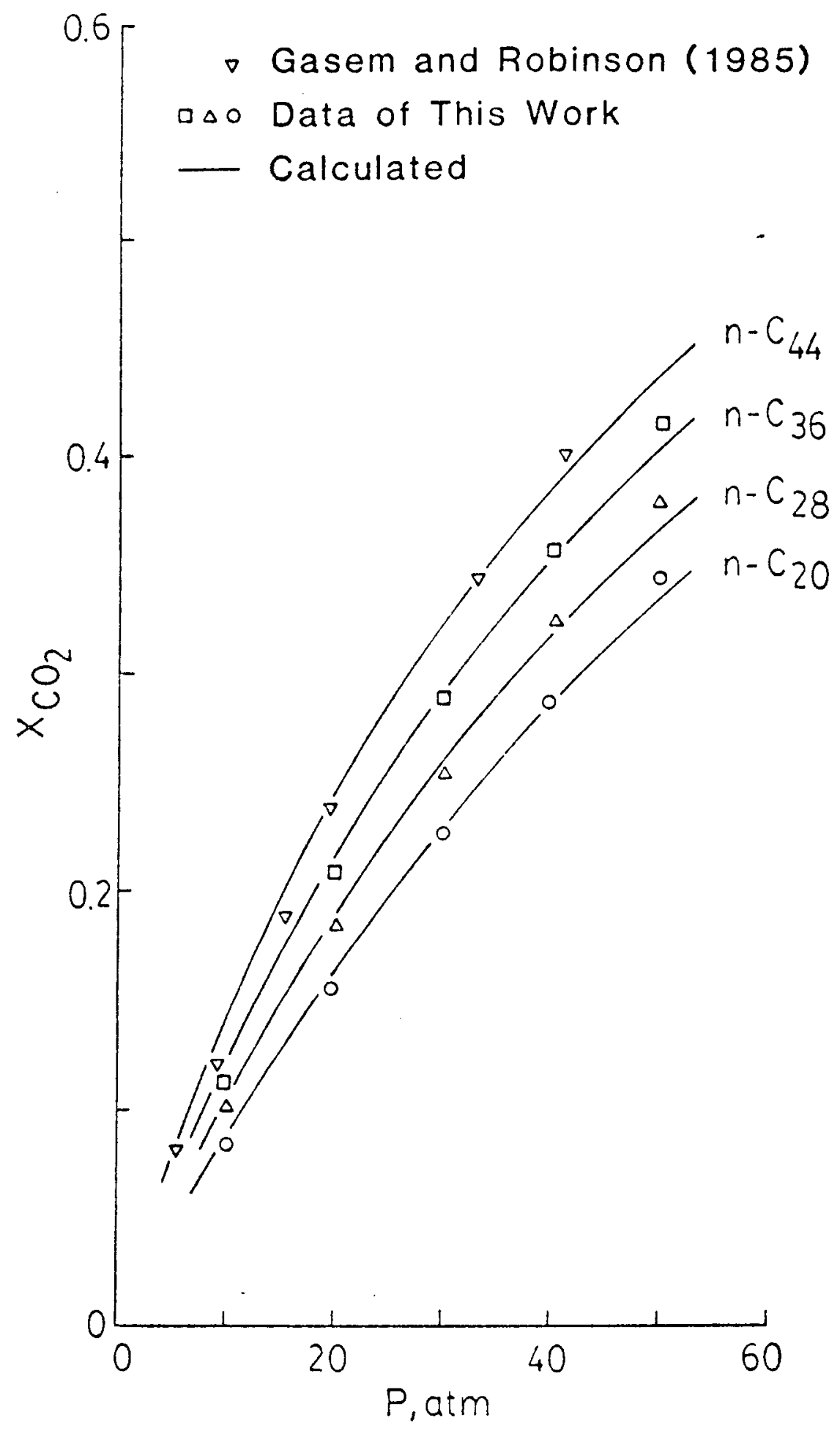

Figure 58. Calculated Carbon Dioxide Solubilities in n-Paraffins at $100^{\circ} \mathrm{C}$ 


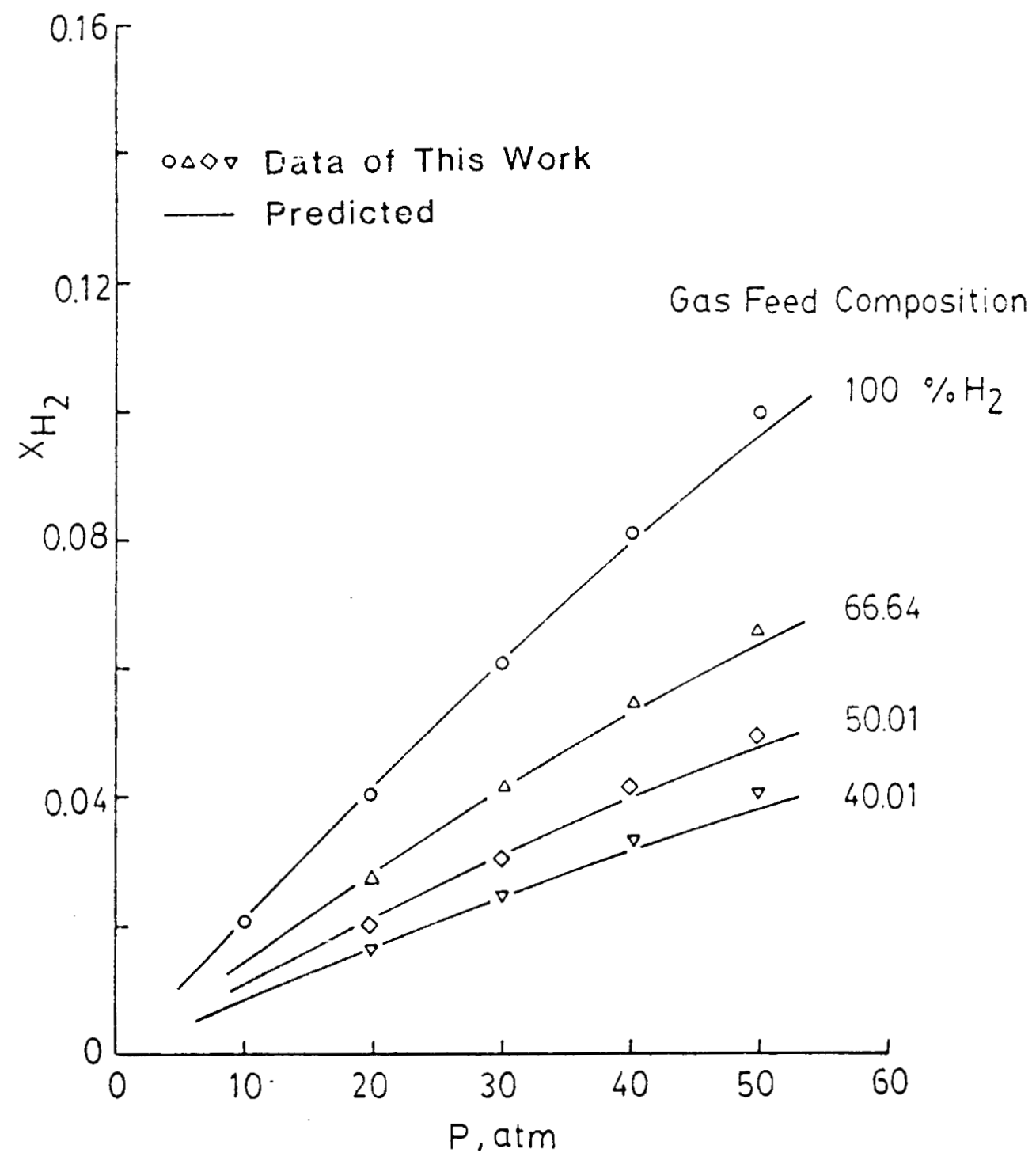

Figure 59. Comparison of Calculated $\mathrm{H}_{2}$ Solubilities in Synthesis Gas Mixtures in n-Octacosane with Experimental Data at $200^{\circ} \mathrm{C}$ 


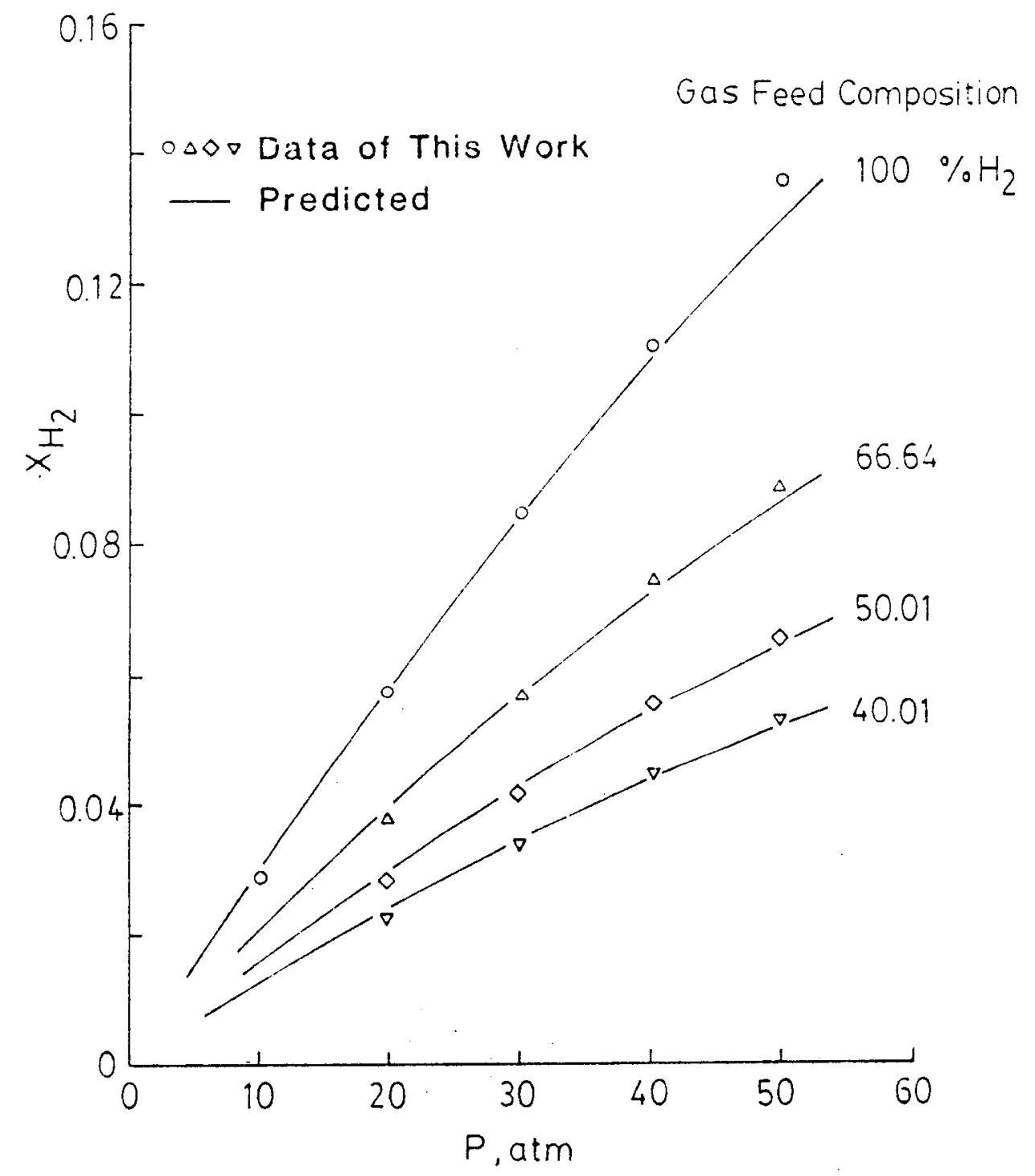

Figure 60. Comparison of Calculated $\mathrm{H}_{2}$ Solubilities in Synthesis Gas Mixtures in n-Octacosane with Experimental Data at $300^{\circ} \mathrm{C}$ 


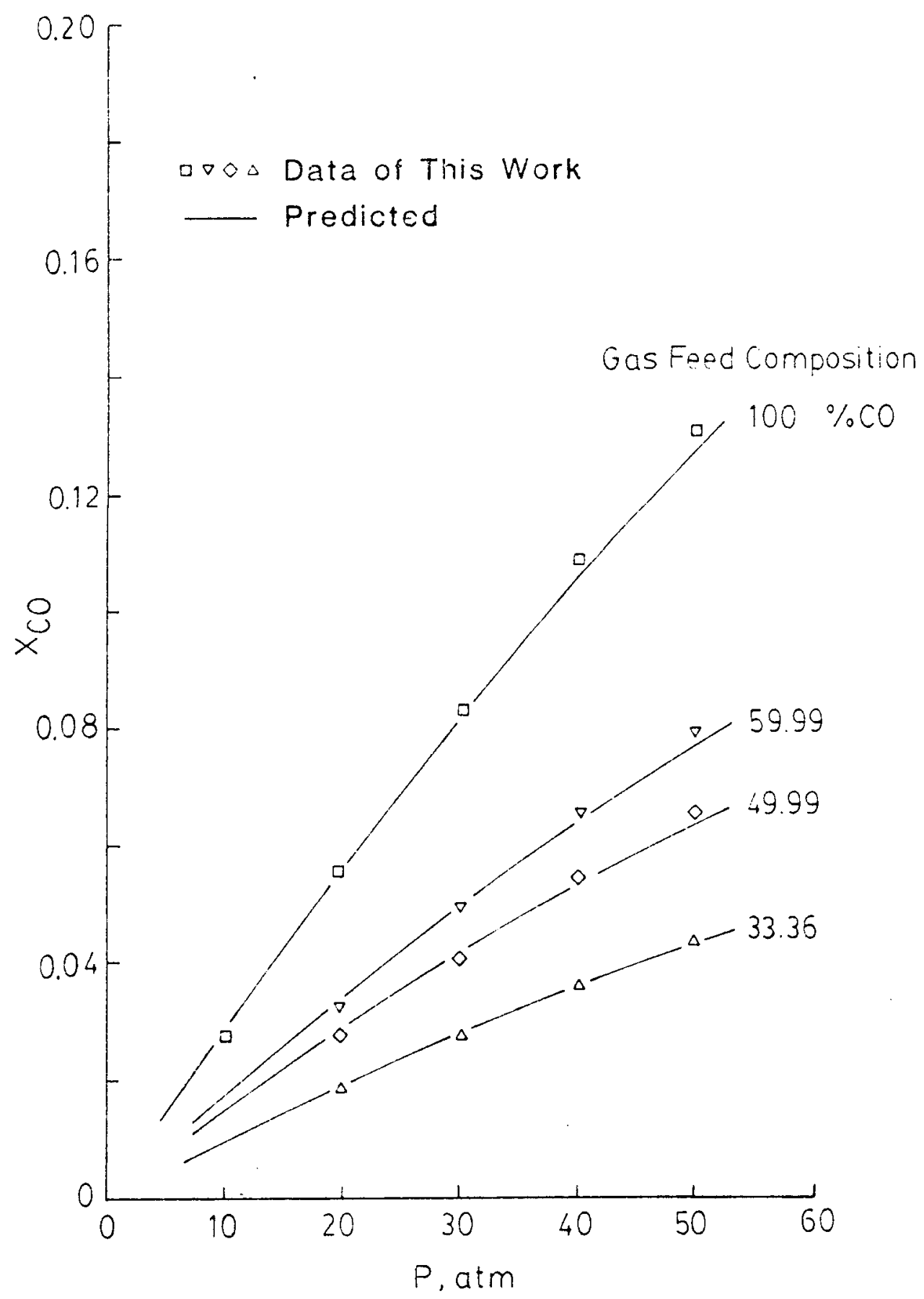

Figure 61. Comparison of Calculated CO Solubilities in Synthesis Gas Mixtures in n-Octacosane with Experimental Data at $200^{\circ} \mathrm{C}$ 


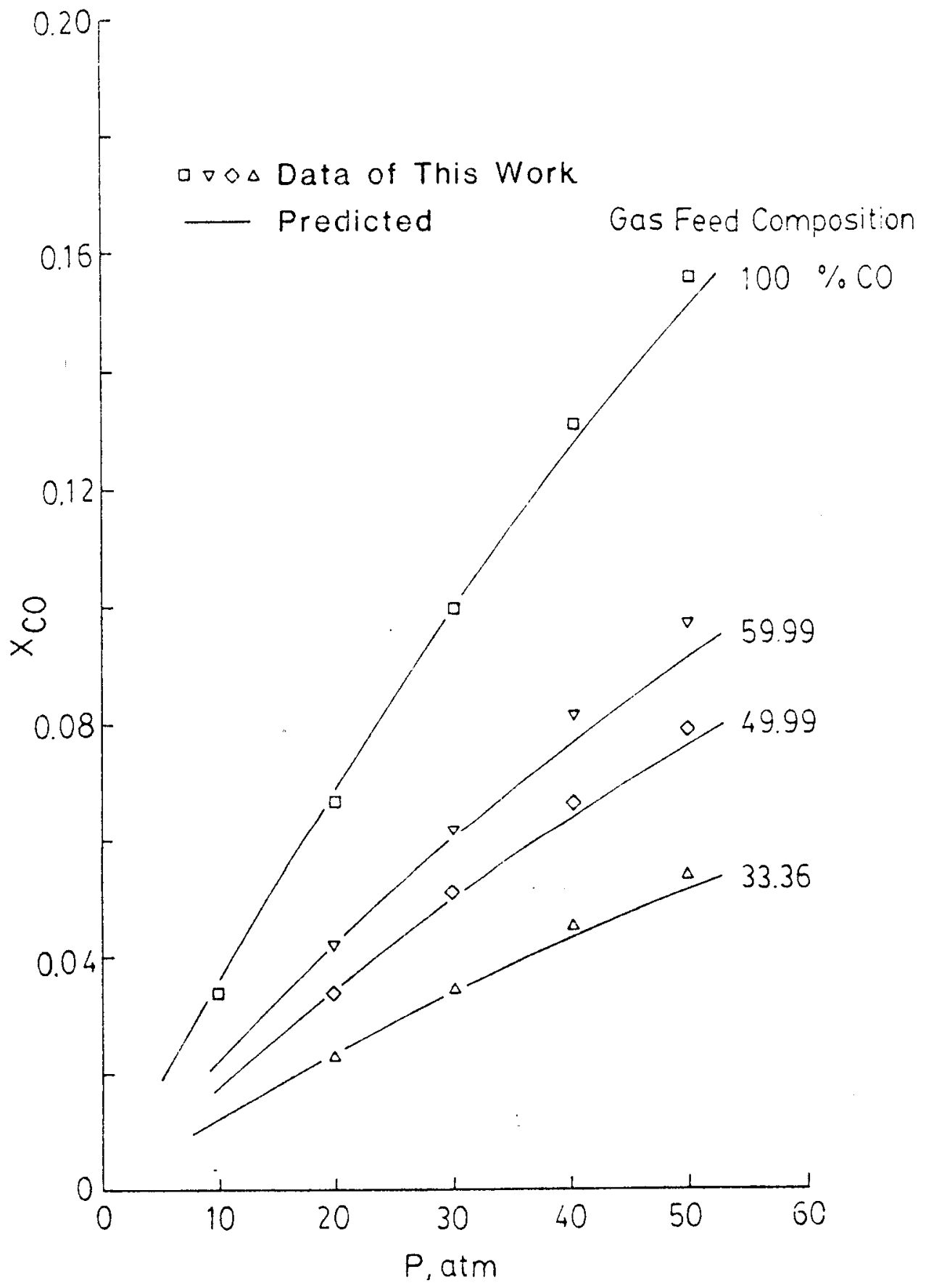

Figure 62. Comparison of Calculated CO Solubilities in Synthesis Gas Mixtures in n-Octacosane with Experimental Data at $300^{\circ} \mathrm{C}$ 


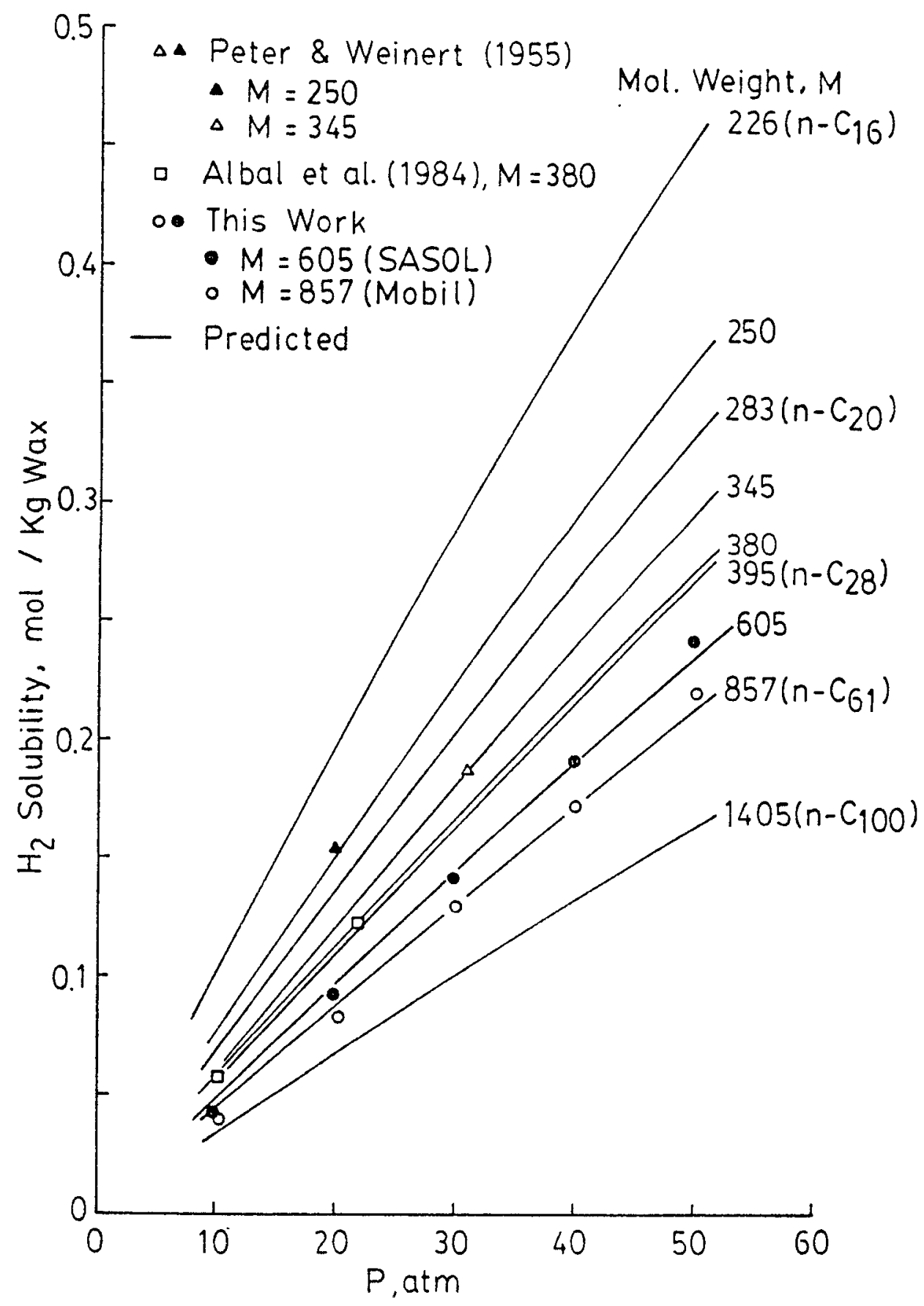

Figure 63. Prediction of Hydrogen Solubilities in Waxes at $200^{\circ} \mathrm{C}$ 


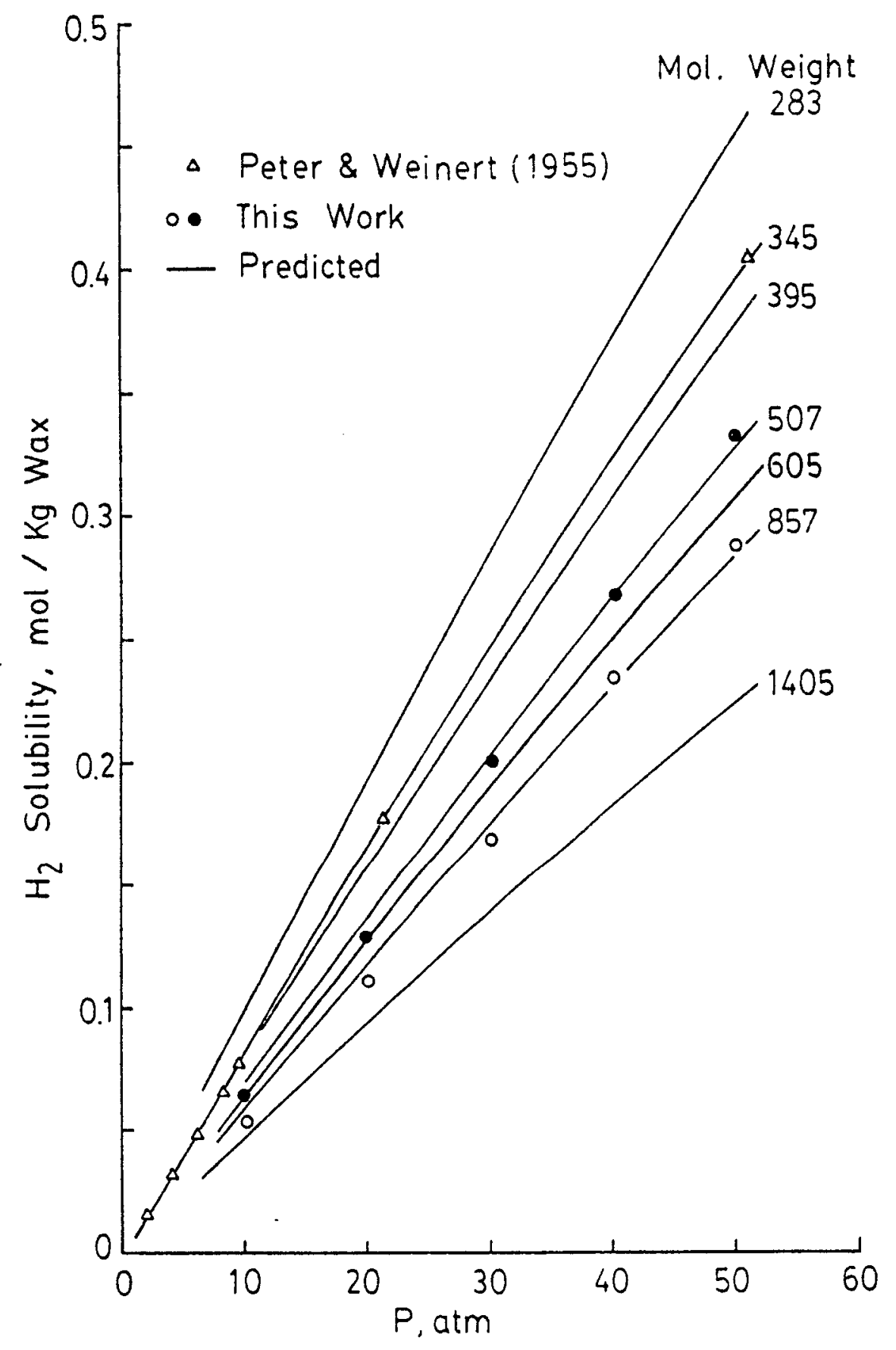

Figure 64. Prediction of Hydrogen Solubilities in Waxes at $300^{\circ} \mathrm{C}$ 


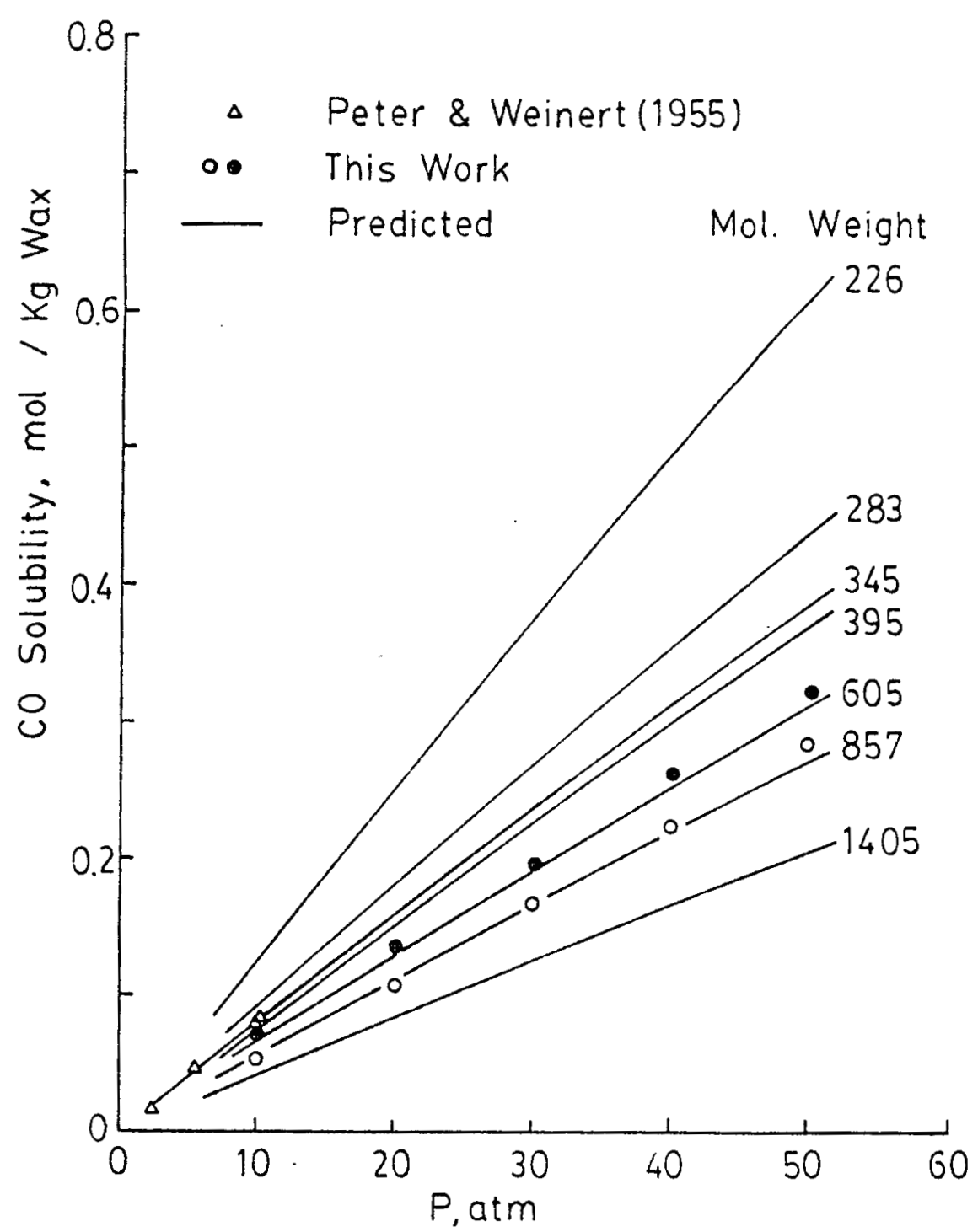

Figure 65. Prediction of Carbon Monoxide Solubilities in Waxes at $200^{\circ} \mathrm{C}$ 


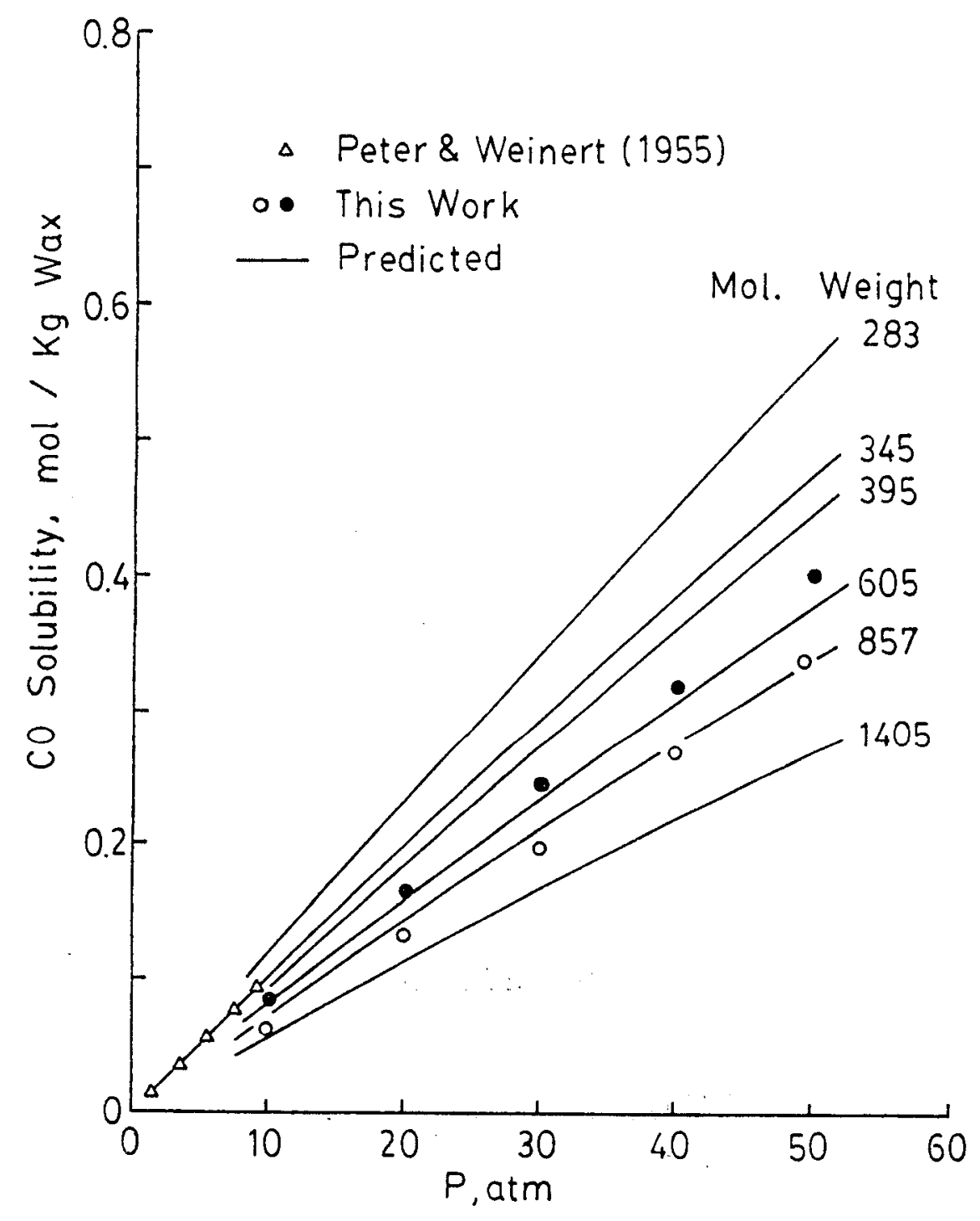

Figure 66. Prediction of Carbon Monoxide Solubilities in Waxes at $300^{\circ} \mathrm{C}$ 


\section{NOTATION}

a constant of Soave equation, eq. 4

AAD average absolute deviation

$A_{i j} \quad$ parameter in eq. 11

$A_{i j}^{x} \quad$ asymptotical value of $A_{i j}$, eq. 15

B coefficients in eq. 8

b constant of Soave equation, eq. 5

C constant in eq. 9

CN carbon number

f fugacity

$\mathrm{g}^{\mathrm{E}} \quad$ excess Gibbs energy

H Henry's constant

K vaporization equilibrium ratio $=\frac{\mathbf{y}}{\mathbf{x}}$

M molecular weight

$M_{0} \quad$ reference molecular weight, eq. 15

m constant, eq. 6

p pressure

R universal gas constant

RMS root mean sequare deviation

$\mathrm{t}$ temperature, ${ }^{\circ} \mathrm{C}$

$\mathbf{T}$ absolute temperature, $\mathbf{K}$

v molar volume

$\overline{\mathbf{v}}^{\mathbf{x}} \quad$ partial molar volume at infinite dilution

$\mathrm{V}$ hard-core volume

$x \quad$ liquid-phase mole fraction

y vapor-phase mole fraction

Greek Letters

$\alpha \quad$ equation constant, eq. 3

$\phi \quad$ volume fraction, eq. 14 
()

Pitzer's acentric factor

Superscripts

$$
\begin{array}{ll}
\mathrm{n} & -\quad \text { constant, eq. } 6 \\
\mathrm{~s} & \quad \text { saturated property }
\end{array}
$$

Subscripts

$\begin{array}{ll}\text { c } & \text { critical state } \\ \text { CD } & \text { carbon dioxide } \\ \text { E } & \text { ethane } \\ \text { H } & \text { hydrogen } \\ \text { i } & \text { component } i \\ \text { j } & \text { component } j \\ \text { r } & \text { reduced property }\end{array}$




\section{REFERENCES}

Albal, R.S., Y.T. Shah, N.L. Carr, and A.T. Bell, Chem. Eng. Sci. 39, 905 (184).

Bondi, A., "Physical Properties of Molecular Crystal, Liquids, and Glasses", John Wiley \& Sons, New York, 1968.

Chappelow, C.C. and J.M. Prausnitz, AIChE J. 20, 1097 (1974).

Gasem, K.A.M. and R.L. Robinson, Jr., J. Chem. Eng. Data 30, 53 (1985).

Gasem, K.A.M. and R.L. Robinson, Jr., "Prediction of Phase Behavior for $\mathrm{CO}_{2}+$ Heavy Normal Paraffins Using Generalized-Parameter Soave and Peng-Robinson Equation of State", private communication, 1986.

Huron, M.J. and J. Vidal, Fluid Phase Equilibria, 3, 255 (1979).

Krichevsky, I.R. and J.S. Kasarnovsky, J. Am. Chem. Soc., 57, 2168 (1935).

Kuo, J.C.W., "Two-stage Process for Conversion of Synthesis Gas to High Quality Transportation Fuels", Final Report for DOE Contract No. DE-AC22-38PC60019, DOE/PC/60019-9, Dist. Category UC-90D, Mobil Research and Development Corporation, Paulsboro, N.J., October, 1985.

Lee, B.I. and M.G. Kesler, AIChE J. 21, 510 (1975).

Matsumoto, D.K. and C.N. Satterfield, Ind. Eng. Chem. Process Des. Dev. 24, 1297 (1985).

Ng, H. and D.B. Robinson, J. Chem. Eng. Data 23, 325 (1978).

Peter, S. and M. Weinert, Z. Phys. Chem. (Neue Folge) $\underline{5} 114$ (1955).

Satterfield, C.N., G.A. Huff, and J.P. Longwell, Ind. Eng. Chem. Process Des. Dev. 21, 465 (1982).

Satterfield, C.N. and H.G. Stenger, Jr., Ind. Eng. Chem. Process Des. Dev. 24, 407 (1985).

Soave, G., Chem. Eng. Sci. 27, 1197 (1972).

Stenger, H.G., Jr., and C.N. Satterfield, Ind. Eng. Chem. Process Des. Dev. 24, 411 (1985).

Stern, D., A.T. Bell, and H. Heinemann, Chem. Eng. Sci. 38, 597 (1983).

UOP Inc., Project Status Report No. 12 for DOE Contract No. DE-AC22- 
85PC80017, "Fischer-Tropsch Wax Characterization and Upgrading", UOP Inc., Des Plaines, Ill., September, 1986. 
Appendix A Computer Program for the Calculation of Gas Solubility

A computer program has been prepared to calculate gas solubility in a nparaffin wax based on the correlation of this work. Solubilities are calculated for any one of the gases $\mathrm{H}_{2}, \mathrm{CO}, \mathrm{CH}_{4}, \mathrm{CO}_{2}, \mathrm{C}_{2} \mathrm{H}_{4}, \mathrm{C}_{2} \mathrm{H}_{6}$ or their mixtures at a specified temperature, pressure, and wax-free mole fractions of the gases in the gas phase. The molecular weight of the wax is specified. The calculation gives the solubilities in mols per $\mathrm{kg}$ of wax and in mole fractions in the liquid. The equilibrium mole fraction of wax in the vapor is also calculated. The program is in FORTRAN.

The input for the program is illustrated below.

\begin{tabular}{|c|c|c|}
\hline Card no. & Format & Variables \\
\hline $\begin{array}{l}1 \\
2 \\
3 \\
4 \text { and after }\end{array}$ & $\begin{array}{l}\text { 2F10.3 } \\
\text { I1 } \\
\text { F10.3 } \\
\text { I1,f10.3 }\end{array}$ & $\begin{array}{l}T \text { in } \mathbf{K} \text { and } \mathbf{P} \text { in atm of the system } \\
\text { number of solutes in the system } \\
\text { molecular weight of the wax } \\
\text { gas identification and vapor phase } \\
\text { composition on wax-free basis }\end{array}$ \\
\hline
\end{tabular}

Gas identification is an interger, which represents a gas species studied in this work.

\begin{tabular}{ll} 
Gas Identification & Gas species \\
\hline 1 & hydrogen \\
2 & carbon monoxide \\
3 & methane \\
4 & carbon dioxide \\
5 & ethane
\end{tabular}

The output lists the calculated liquid phase composition of each solute and the wax mol fraction in the vapor phase. 


\section{Program List}

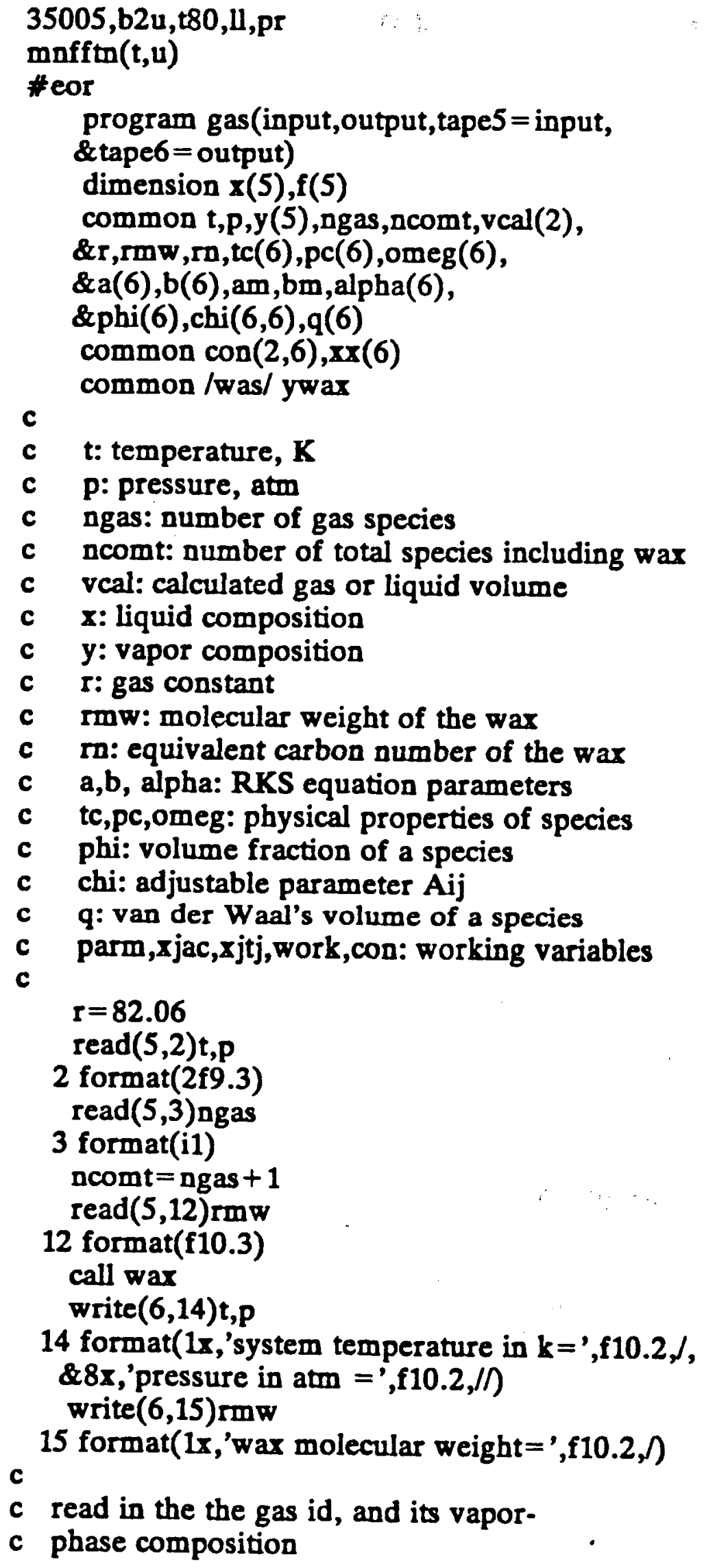


c

do $20 \mathrm{n} 1=1$, $\mathrm{ncom} t$

do $20 \mathrm{n} 2=1$, ncomt

$20 \mathrm{chi}(\mathrm{n} 1, \mathrm{n} 2)=0.0$

write $(6,22)$

22 format $(/, 1 x$,'species no.',5x,'species',12x,

\&'y on wax-free basis')

do $39 \mathrm{j} 1=1$, ngas

$\operatorname{read}(5,25) \mathrm{id}, \mathrm{y}(\mathrm{j} 1)$

25 format $(i 1,2 f 10.4)$

$x(j 1)=y(j 1) / 10$.

call gprop(id,j1)

39 continue

ywax $=0.0$

write $(6,49)$ ncomt, ywax

49 format(4x,i1,12x,'wax ',12x,f12.4)

do $50 \mathrm{n} 1=1, \mathrm{ncomt}$

50 chi(ncomt,n1) = chi $(n 1, n c o m t)$

c

c call subroutine to find the liquid composition.

c

do 100 icont $=1,10$

call obj $(\mathbf{x}, \mathbf{f})$

$\operatorname{grad}=0.0$

do $60 \mathrm{n} 1=1$, ngas

$60 \operatorname{grad}=\operatorname{grad}+\operatorname{abs}(\mathrm{f}(\mathrm{n} 1) / \mathrm{x}(\mathrm{n} 1)-1.0)$

if(grad-5.0e-5) $110,90,90$

90 do $95 \mathrm{n} 1=1$,ngas

$95 \times(n 1)=f(n 1)$

100 continue

110 write $(6,118)$

118 format $(/ /$,'species no.',5x,'calc. $y$ ',5x,

\&'calc. x',7x,'solubility',/,

$\& 42 x$,'(mol per $\mathrm{kg}$ wax)',

$\operatorname{dum} x=0.0$

dumy $=0.0$

do $150 \mathrm{j} 1=1$, ngas

sol $=x(j 1) /(1.0-x(j 1)) / r m w * 1000.0$

$\operatorname{dum} x=\operatorname{dum} x+\operatorname{con}(1, j 1)$

dumy $=\operatorname{dumy}+\operatorname{con}(2, \mathrm{j} 1)$

write $(6,120) \mathrm{j} 1, \operatorname{con}(2, \mathrm{j} 1), \mathrm{x}(\mathrm{j} 1)$, sol

120 format $(1 x, \mathrm{i} 3,4 x, \mathrm{f} 12.4,3 x, \mathrm{e} 12.3,4 x, \mathrm{e} 12.3)$

150 continue

$\operatorname{dum} x=\operatorname{dum} x+\operatorname{con}(1, \mathrm{ncom} t)$

dumy $=$ dumy $+\operatorname{con}(2, n \operatorname{com} t)$

write $(6,130)$ ncomt, $\operatorname{con}(2, \mathrm{ncomt}), \operatorname{con}(1, \mathrm{ncomt})$

130 format (1x,i3,4x,f12.4,3x,e12.3,12x,'-') 
write $(6,140)$ dumy, dumx

140 format (/,1x,'total',3x,\$12.4,1x,f12.4,/)

stop

end

subroutine obj $(x, f)$

c

c this subroutine set the objective function to be

c minimized by the levenberg-marquardt algorithm

c

dimension coef $(4), f u(2,6), x(5), f(5)$

common $t, p, y(5)$, ngas, ncomt,vcal(2),

$\& \mathrm{r}, \mathrm{rmw}, \mathrm{rn}, \mathrm{tc}(6), \mathrm{pc}(6), \mathrm{omeg}(6)$,

$\& a(6), b(6), a m, b m$, alpha(6),

\&phi(6), chi(6,6), q(6)

common $\operatorname{con}(2,6), \operatorname{xx}(6)$

common /was/ ywax

complex $z(3)$

$\operatorname{con}(1, \mathrm{ncom} t)=1.0$

$\operatorname{con}(2, \mathrm{ncom} t)=y w a x$

do $10 \mathrm{i} 0=1$, ngas

$\operatorname{con}(1, \mathrm{i} 0)=\mathrm{x}(\mathrm{i} 0)$

$\operatorname{con}(2, \mathrm{i} 0)=(1.0-y w a x) * y(\mathrm{i} 0)$

$\operatorname{con}(1, n \operatorname{com} t)=\operatorname{con}(1, \mathrm{ncom} t)-\operatorname{con}(1, \mathrm{i} 0)$

10 continue

$\operatorname{con}(1, n \operatorname{com} t)=a b s(\operatorname{con}(1, n \operatorname{com} t))$

do $50 \mathrm{j} 1=1$, ncomt

$\mathrm{tr}=\mathrm{t} / \mathrm{tc}(\mathrm{j} 1)$

call calal $(\mathrm{j} 1, \mathrm{tr})$

$a(j 1)=0.42747^{*} \mathrm{alpha}(\mathrm{j} 1)^{*} \mathrm{r}^{*} \mathrm{r}^{*} \mathrm{tc}(\mathrm{j} 1)^{\circ} \mathrm{tc}(\mathrm{j} 1) / \mathrm{pc}(\mathrm{j} 1)$

$b(j 1)=0.08664^{\circ} \mathrm{r}^{\circ} \mathrm{tc}(\mathrm{j} 1) / \mathrm{pc}(\mathrm{j} 1)$

50 continue

do $90 \mathrm{i} 1=1,2$

call mix(i1)

call mixb(i1)

call mixa(i1)

rtop $=r^{*} t / p$

$\operatorname{coef}(1)=1.0$

$\operatorname{coef}(2)=-$ rtop

$\operatorname{coef}(3)=-b m^{*} r t o p-b m " b m+a m / p$

$\operatorname{coef}(4)=-b m * a m / p$

call zrpoly (coef, $3, z$,ier)

$\operatorname{vcal}(1)=\operatorname{real}(z(1))$

$\operatorname{vcal}(2)=\operatorname{real}(z(3))$

do $90 \mathrm{j} 1=1$, ncomt

call rabrn(i1,j1,dadxi,dbdxi)

call fugac(fu,vcal(i1),i1,j1,dadxi,dbdxi) 


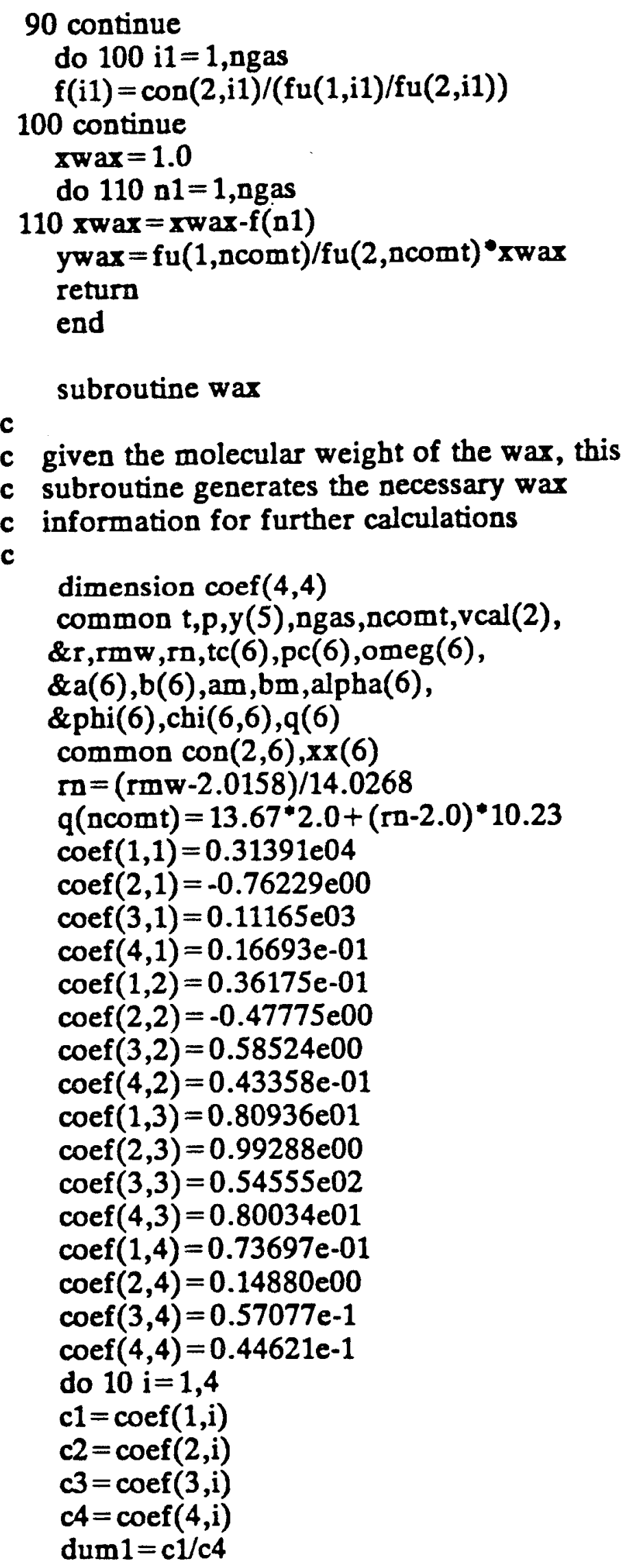




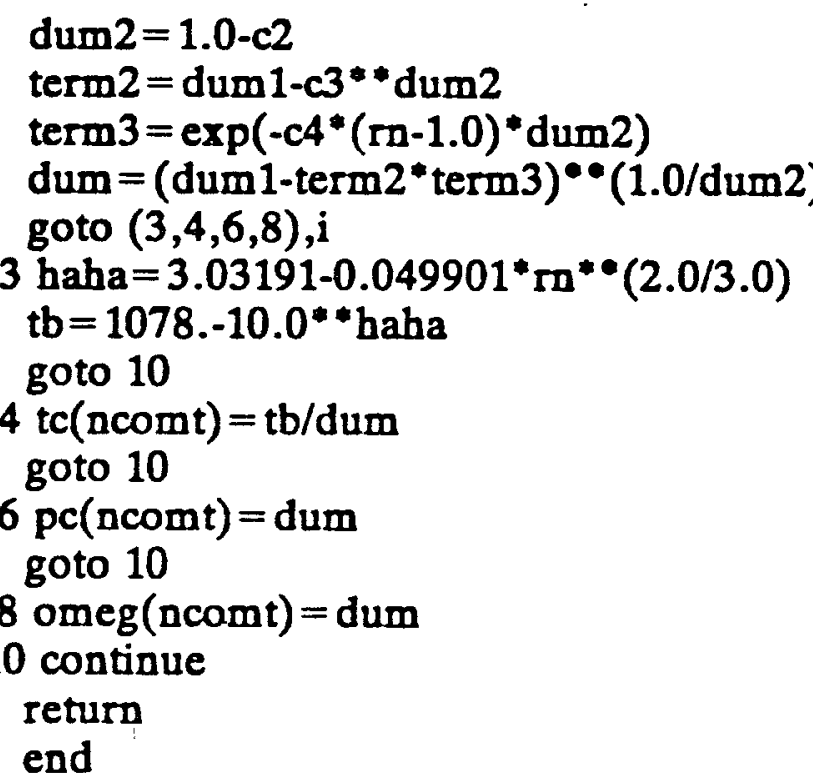

subroutine gprop(id,j1)

common t,p,y(5), ngas, ncomt, vcal(2),

$\& \mathrm{r}, \mathrm{rmw}, \mathrm{rn}, \mathrm{tc}(6), \mathrm{pc}(6), \operatorname{omeg}(6)$,

$\& a(6), b(6), a m, b m, a l p h a(6)$,

\&phi(6), chi $(6,6), q(6)$

c

common $\operatorname{con}(2,6), \operatorname{xx}(6)$

c this subroutine generates the gas information nceded

c for calcuations

c

goto $(10,20,30,40,50)$,id

10 write $(6,11) \mathrm{j} 1, \mathrm{y}(\mathrm{j} 1)$

11 format $(4 \mathrm{x}, \mathrm{i1}, 12 \mathrm{x}$;'hydrogen ',9x,f12.4)

$\operatorname{tc}(j 1)=33.2$

$\operatorname{pc}(\mathrm{j} 1)=12.8$

$\operatorname{omeg}(j 1)=-0.22$

$q(j 1)=10.51$

$\mathrm{a} 1=0.2456$

$\mathrm{a} 2=0.2406$

$\mathrm{rmw} 0=127.30$

goto 100

20 write $(6,21) \mathrm{j} 1, y(j 1)$

21 format $(4 x, 11,12 x$,'carbon monoxide', $3 x, f 12.4)$

$\operatorname{tc}(j 1)=132.9$

$\mathrm{pc}(\mathrm{j} 1)=34.5$

$\operatorname{omeg}(j 1)=0.049$

$\mathrm{q}(\mathrm{j} 1)=13.01$

$\mathrm{a} 1=0.1723$

$\mathrm{a} 2=0.1707$

$\mathrm{rmw} 0=140.75$ 
goto 100

30 write $(6,31) \mathrm{j} 1, \mathrm{y}(\mathrm{j} 1)$

31 format $(4 x, 11,12 x$,'methane ',9x,f12.4)

$\operatorname{tc}(j 1)=190.6$

$p c(j 1)=45.4$

$\operatorname{omeg}(\mathrm{j} 1)=0.008$

$q(j 1)=17.09$

a1 $=0.1009$

$22=0.1050$

rmw0 $=146.06$

goto 100

40 write $(6,41) j 1, y(j i)$

41 format $(4 x, 11,12 x$,'carbon dioxide ',3x,f12.4)

$\operatorname{tc}(\mathrm{j} 1)=304.2$

$\mathrm{pc}(\mathrm{j} 1)=72.8$

$\operatorname{omeg}(j 1)=0.225$

$q(j 1)=19.68$

$\mathrm{a} 1=0.09710$

$\mathrm{a} 2=0.09240$

rmw0 $=137.02$

goto 100

50 write $(6,51) \mathrm{j} 1, y(j 1)$

51 format $(4 x, \mathrm{i} 1,12 x$,'ethane ',9x,f12.4)

$\operatorname{tc}(j 1)=305.4$

$\operatorname{pc}(\mathrm{j} 1)=48.2$

$\operatorname{ormeg}(\mathrm{j} 1)=0.098$

$\mathrm{q}(\mathrm{j} 1)=27.34$

$\mathrm{a} 1=0.04967$

$\mathrm{a} 2=0.05277$

$\mathrm{rmw} 0=188.16$

100 factor $=1.0-\exp (-\mathrm{rmw} / \mathrm{rmw} 0)$

$\operatorname{chi}(j 1, \mathrm{ncomt})=\left(\mathrm{a} 1+(\mathrm{a} 2-\mathrm{a} 1)^{\bullet}(\mathrm{t}-473.2) / 100.0\right)^{*}$ factor

return

end

subroutine calal $(\mathrm{j} 1, \mathrm{tr})$

c

c this subroutine calculates equation parameter

c alpha for each species

c

common t,p,y(5), ngas,ncomt,vcal(2),

\&r,rmw, rn,tc(6),pc(6), omeg(6),

\&a(6), b(6),am,bm,alpha(6),

\&phi(6),chi(6,6), $q(6)$

common con $(2,6), \mathrm{xx}(6)$

if (tc $(\mathrm{j} 1)-550.) 10,10,40$

10 dum $=$ omeg $(j 1)$ 


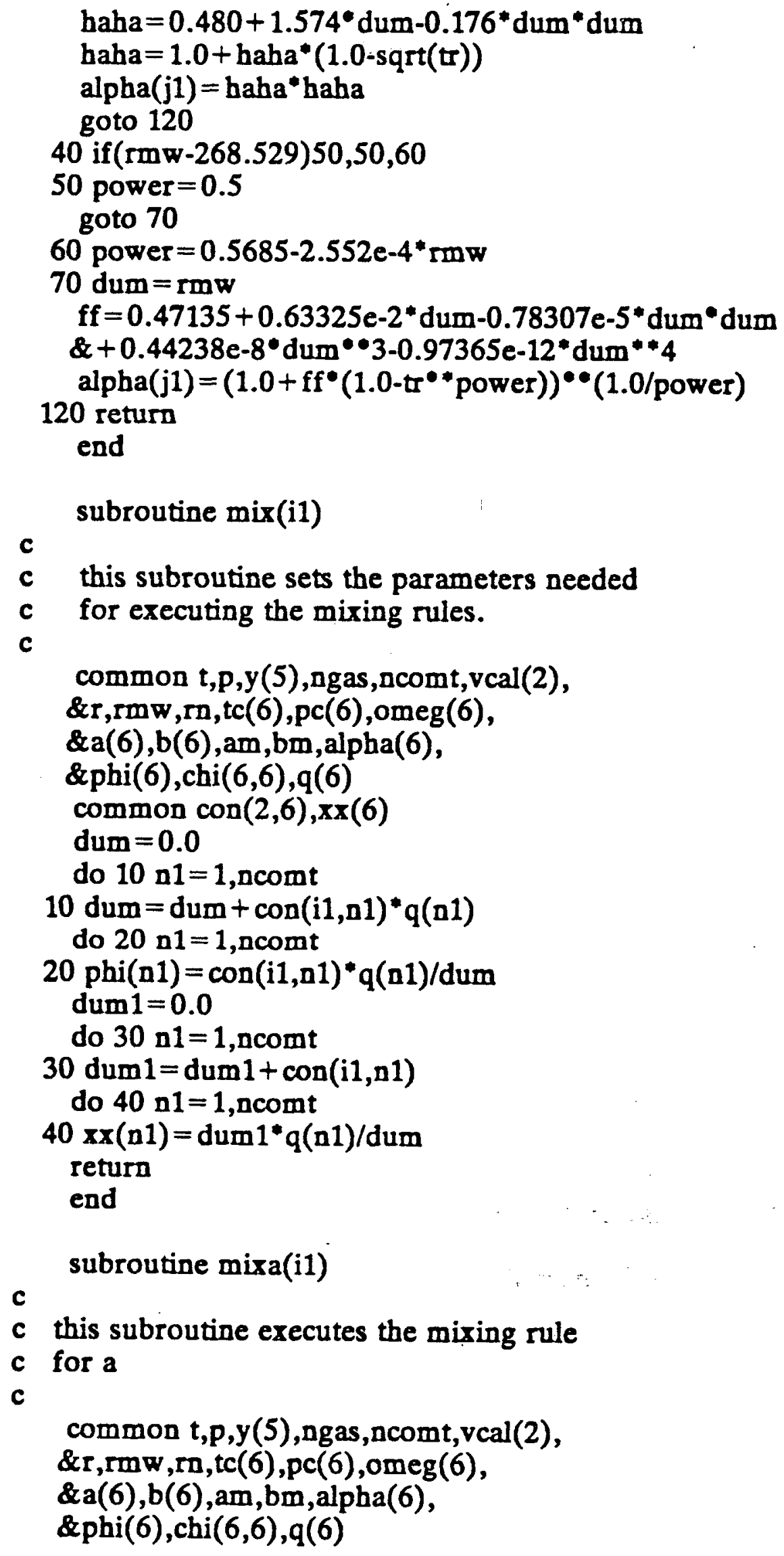




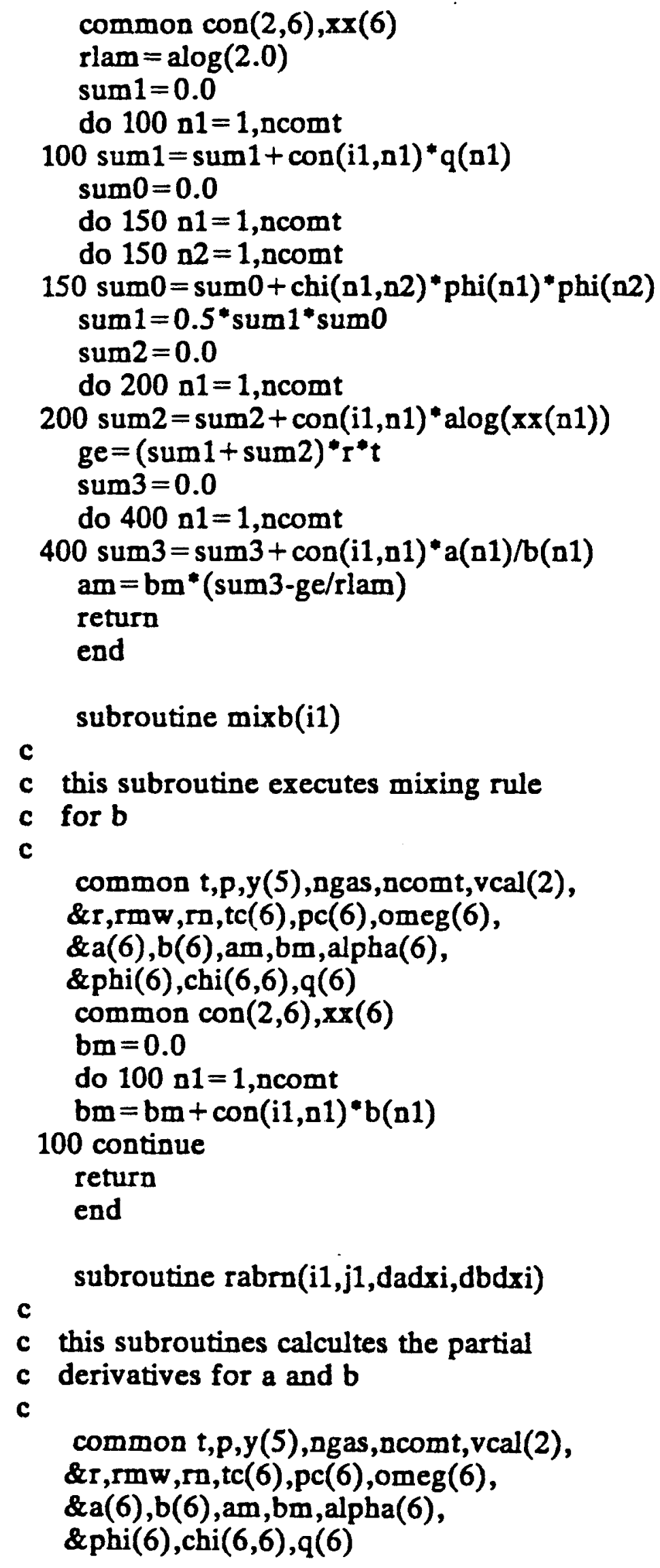




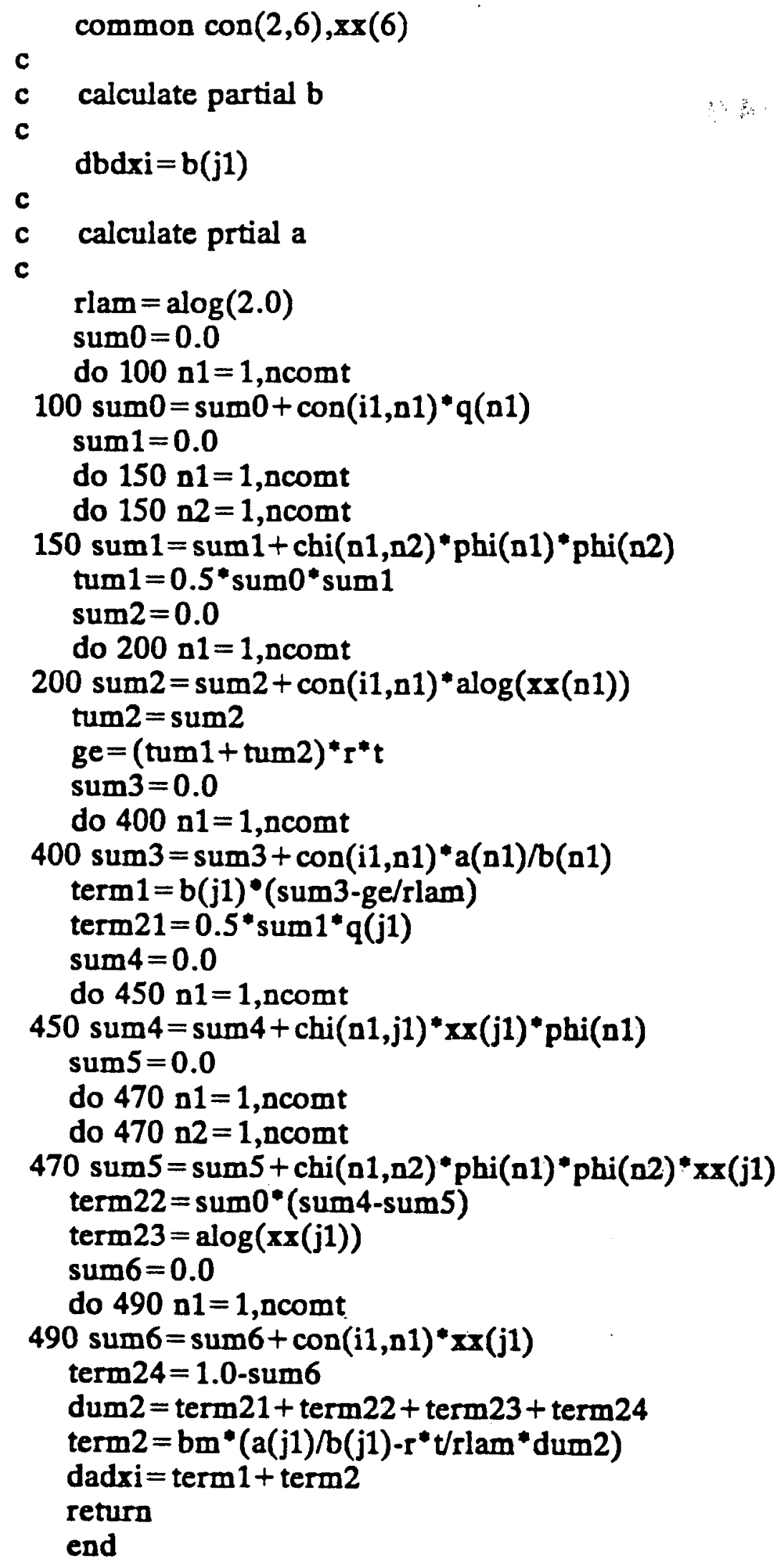

subroutine fugac(fu,v,i1,j1,dadxi,dbdxi) 


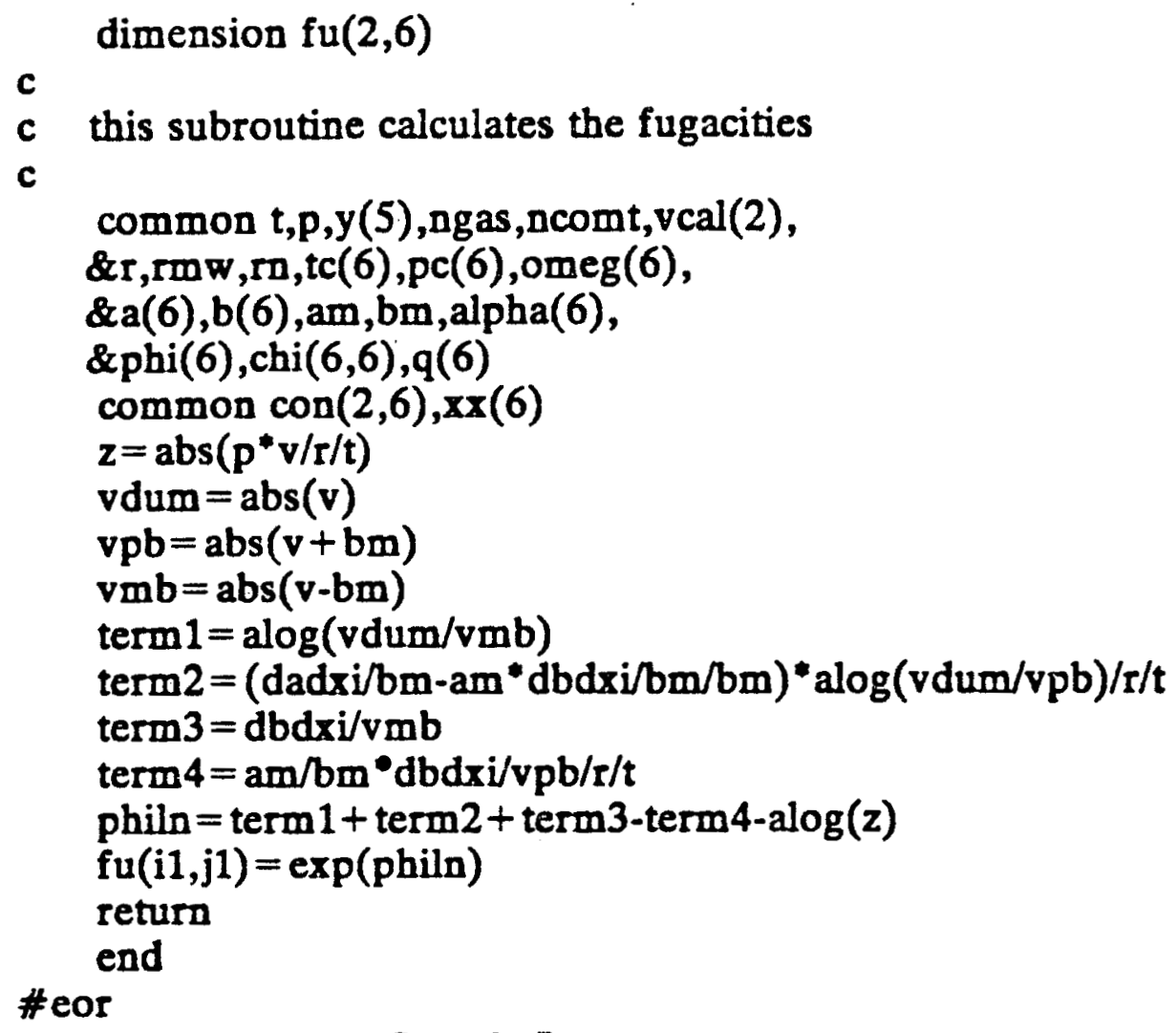
Sample Input-

$573.2 \quad 20.00 \quad t(K)$ and $p(a t m)$ of the system; $2 f 10.3$

5

394.77 number of gases; i1 molecular weight of wax; $; 10.3$

$\begin{array}{ll}1 & 0.3000\end{array}$ gas id. and $y$ in mol fraction; $11,2 \mathrm{f} 10.3$

20.3000

$3 \quad 0.0500$

$\begin{array}{ll}4 & 0.3000\end{array}$

$5 \quad 0.0500$

\# eof

Sample Output

system temperature in $\mathrm{k}=\quad \mathbf{5 7 3 . 2 0}$

pressure in atm $=\quad 20.00$

wax molecular weight $=\quad 394.77$

species 1 gas $\mathrm{id}=1$

species 2 gas $\mathrm{id}=2$

species 3 gas $\mathrm{id}=3$

species 4 gas id $=4$

species 5 gas $\mathrm{id}=5$ 


$\begin{array}{cccc}\text { species } & y & \text { calc. } x & \begin{array}{c}\text { solubility } \\ \text { (mol per kg wax) }\end{array} \\ 1 & .3000 & .173 \mathrm{e}-01 & .445 \mathrm{e}-01 \\ 2 & .3000 & .204 \mathrm{e}-01 & .527 \mathrm{e}-01 \\ 3 & .0500 & .520 \mathrm{e}-02 & .132 \mathrm{e}-01 \\ 4 & .3000 & .380 \mathrm{e}-01 & .100 \mathrm{e}+00 \\ 5 & .0500 & .870 \mathrm{e}-02 & .222 \mathrm{e}-01\end{array}$

wax mole fraction in vapor phase $=\quad .165 \mathrm{e}-02$ 